\title{
How do symbiotic associations in lecideoid lichens respond to different environmental conditions along the Transantarctic Mountains, Ross Sea region, Antarctica?
}

Monika Wagner'1, Georg Brunauer1 ${ }^{1}$ Arne C. Bathke², S. Craig Cary33,4, Roman Fuchs', Leopoldo G. Sancho5, Roman Türk1, *Ulrike Ruprecht ${ }^{1}$

1Department of Biosciences, Paris Lodron Universität Salzburg, Salzburg, Austria

2Department of Mathematics, Paris Lodron Universität Salzburg, Salzburg, Austria

${ }^{3}$ School of Science, The University of Waikato, Hamilton, New Zealand

${ }^{4}$ The International Centre for Terrestrial Antarctic Research, School of Science, The University of Waikato, Hamilton, New Zealand

${ }^{5}$ Botany Unit, Facultad de Farmacia, Universidad Complutense de Madrid, Madrid, Spain

${ }^{*}$ Corresponding Author:

Ulrike Ruprecht, ulrike.ruprecht@sbg.ac.at, ORCID 0000-0002-0898-7677

\section{Abstract}

Lecideoid lichens as dominant vegetation-forming organisms in the climatically harsh areas of the southern part of continental Antarctica show clear preferences in relation to environmental conditions (i.e. macroclimate). 306 lichen samples were included in the study, collected along the Ross Sea coast $\left(78^{\circ} \mathrm{S}-85.5^{\circ} \mathrm{S}\right)$ at six climatically different sites. The species compositions as well as the associations of their two dominant symbiotic partners (myco-and photobiont) were set in context with environmental conditions along the latitudinal gradient. Diversity values were nonlinear with respect to latitude, with the highest alpha diversity in the milder areas of the McMurdo Dry Valleys $\left(78^{\circ} \mathrm{S}\right.$ ) and the most southern areas (Durham Point, $85.5^{\circ} \mathrm{S}$; Garden Spur, $84.5^{\circ} \mathrm{S}$ ), and lowest in the especially arid and cold Darwin Area $\left(\sim 79.8^{\circ} \mathrm{S}\right)$. Furthermore, the specificity of mycobiont species towards their photobionts decreased under more severe climate conditions. The generalist lichen species Lecanora fuscobrunnea and Lecidea cancriformis were present in almost all habitats, but were dominant in climatically extreme areas. Carbonea vorticosa, Lecidella greenii and Rhizoplaca macleanii were confined to milder areas.

In summary, the macroclimate is considered to be the main driver of species distribution, making certain species useful as bioindicators of climate conditions and, consequently, for detecting climate change.

\section{Keywords}

Southernmost areas in Antarctica, latitudinal gradient, polar desert, macroclimate, microhabitat, myco-/photobiont associations 
bioRxiv preprint doi: https://doi.org/10.1101/2021.05.26.445136; this version posted May 27, 2021. The copyright holder for this preprint (which was not certified by peer review) is the author/funder, who has granted bioRxiv a license to display the preprint in perpetuity. It is made available under aCC-BY-NC-ND 4.0 International license.

Symbiotic associations in lecideoid lichens along the Transantarctic Mountains, Antarctica

Wagner et al. 2021

\section{Introduction}

Polar deserts of the southernmost areas in continental Antarctica are characterized by exceptionally hostile climatic conditions, such as particularly low temperatures and high aridity (Adams et al. 2006; Cary et al. 2010; Magalhaes et al. 2012).Terrestrial life is restricted to ice-free areas, which, apart from a few nunataks, are mainly located along the Transantarctic Mountains forming the west coast of the Ross Sea and Ross Ice Shelf (Monaghan et al. 2005). Because of these special conditions, terrestrial life is rare and can only be found in small areas protected from extreme environmental influences, such as abrasion from windblown particles or high solar radiation, the so-called microhabitats (Hertel 1998; Ruprecht et al. 2012b). They are characterized by sheltered areas in rock crevices or small cavities shielded from the wind and sun that allow life on a small scale in an otherwise hostile environment. The rock surface is often highly weathered which results in a higher water retention capacity, providing the most needed life source for the organisms to survive (Colesie et al. 2014; Green 2009). The only moisture available to rock-dwelling organisms is provided by clouds, fog, dew, sparse precipitation and melting snow (Head and Marchant 2014; Wagner et al. 2020). Additionally, the aspect of the slopes, ridges and depressions as well as the wind regime has an important impact by creating different surface temperatures in small areas (McKendry and Lewthwaite 1990; Yung et al. 2014). However, microhabitats are influenced by both macroclimate and geography, and their life-supporting properties therefore vary along environmental gradients reflected in changing diversity levels and biogeography of Antarctic terrestrial biota (Baird et al. 2019; Lagostina et al. 2021; Magalhaes et al. 2012; Peat et al. 2007; Fig.1; Ruprecht et al. 2012a; Fig.1).

The terrestrial vegetation along the Ross Sea coast (extending from $72^{\circ} \mathrm{S}$, Cape Hallett, to $85.5^{\circ} \mathrm{S}$, Queen Maud Mountains) is entirely composed of cryptogrammic organisms and dominated by lichens and mosses (Colesie et al. 2014; Ochyra et al. 2008; Peat et al. 2007). Remarkably, the biodiversity of these organisms does not decrease evenly along the latitudinal gradient as one might expect. In fact, the lowest species diversity was recorded at about $79^{\circ} \mathrm{S}$ at Diamond Hill (Darwin Area), which has by far the harshest climate conditions (lowest humidity; Colesie et al. 2014). However, nonlinear climatic conditions along gradients caused by additional factors, e.g. special wind systems, can be detected effectively with biological systems that act as bioindicators (Dal Grande et al. 2017; Sancho et al. 2019; Singh et al. 2017; Wagner et al. 2020). Additionally, they not only enable the survey of the current state but can also reliably indicate changes in environmental conditions. Due to the structure and diversity of communities, the abundance and distribution of species as well as processes varying along environmental gradients are therefore powerful longterm and large-scale study systems to estimate the consequences of climate change on ecosystems (Sundqvist et al. 2013).

The most abundant vegetation-forming organisms in these areas are lichens, in most of the cases with a crustose thallus fused to the rocky surface or deeply embedded in crevices (Colesie et al. 2014; De los Rios et al. 2004; Hertel 2007; Kappen and Valladares 2007; Ruprecht et al. 2012b). The poikilohydric lifestyle of lichens enables them to survive the harsh climate conditions and the long periods without water and/or light in a dormant state (Schroeter et al. 2011). The symbiotic lifeform of lichens consists of two dominant symbiotic partners: the mycobiont (fungus) and the photosynthetic partner (green algae and/or cyanobacteria: photobiont) and additional associated fungal, algal and bacterial communities forming the holobiome lichen thallus (Aschenbrenner et al. 2016; Grube et al. 2015; Lawrey and Diederich 2003; Ruprecht et al. 2014; Spribille et al. 2016). Therefore, lichens constitute an excellent model for analyzing multi-species associations in one unit to reveal phylogenetic and ecological responses for symbiotic associations. 
bioRxiv preprint doi: https://doi.org/10.1101/2021.05.26.445136; this version posted May 27, 2021. The copyright holder for this preprint (which was not certified by peer review) is the author/funder, who has granted bioRxiv a license to display the preprint in perpetuity. It is made available under aCC-BY-NC-ND 4.0 International license.

Symbiotic associations in lecideoid lichens along the Transantarctic Mountains, Antarctica

Wagner et al. 2021

Many analyses focused on myco-/photobiont associations have demonstrated that they react sensitively to even small environmental gradients (Dal Grande et al. 2018; Wagner et al. 2020). These results allow the conclusion that mycobionts which are less specialized to specific locations and are able to use a broader range of photobionts, such as the widespread species Lecidea cancriformis in continental Antarctica (Ruprecht et al. 2012a; Wagner et al. 2020), are less vulnerable to climate changes. Low photobiont specificity may improve the performance of the lichen symbiosis, e.g. by increasing the adaptive potential to new
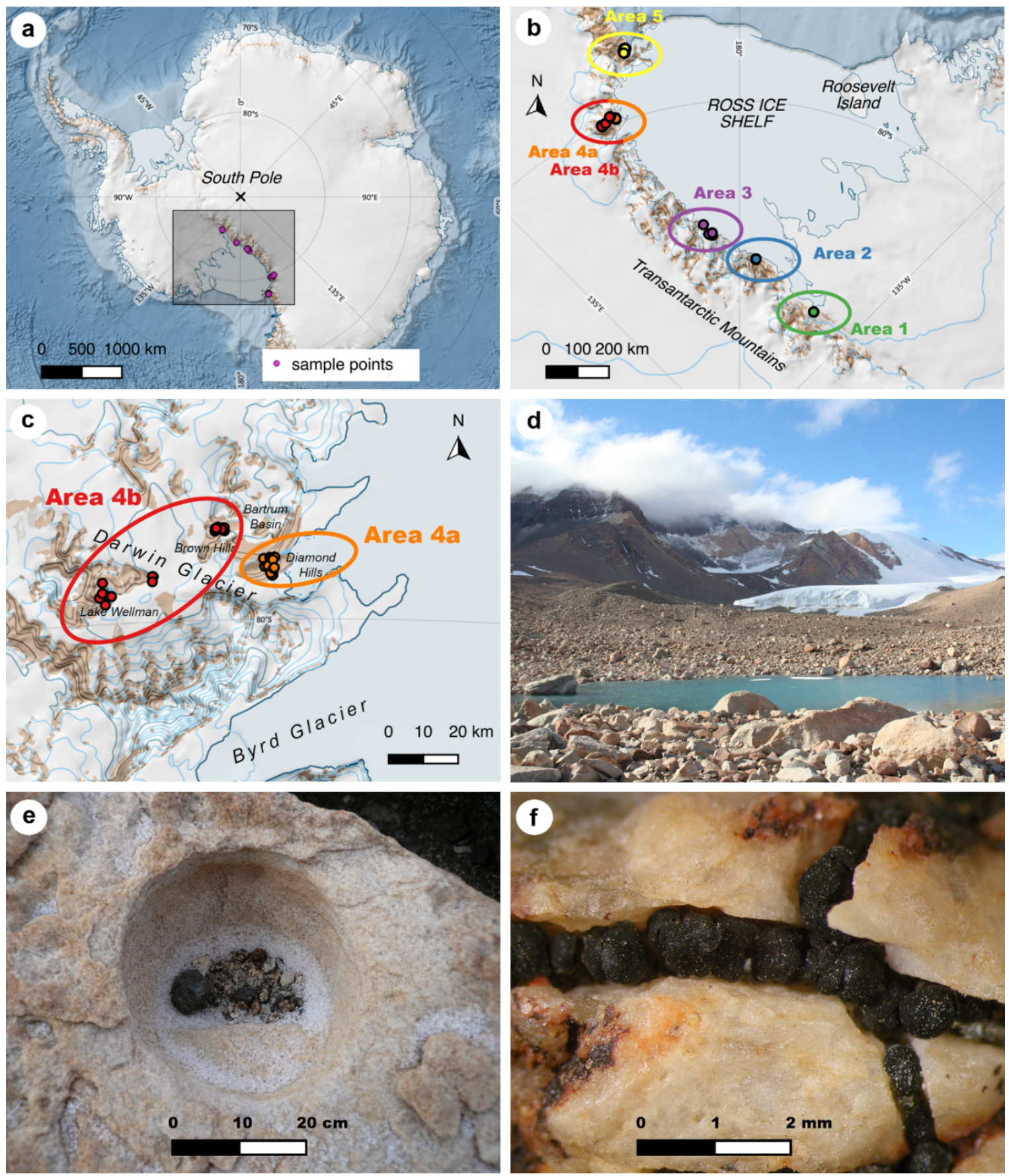

Figure 1. Location of the sample points and lichen habitats. (a) Antarctic continent, investigated area marked with rectangle, (b) location of the six different areas defined in the study, (c) differentiation of area 4 in subareas $4 a$ and $4 b$, (d) Batrum Basin, (e) microhabitat with crustose lichens at Lake Wellman, (f) chasmolithic growth of Lecidea cancriformis. Maps of (a), (b) and (c) are based on the dataset Quantarctica (Matsuoka et al. 2018). 
bioRxiv preprint doi: https://doi.org/10.1101/2021.05.26.445136; this version posted May 27, 2021. The copyright holder for this preprint (which was not certified by peer review) is the author/funder, who has granted bioRxiv a license to display the preprint in perpetuity. It is made available under aCC-BY-NC-ND 4.0 International license.

Symbiotic associations in lecideoid lichens along the Transantarctic Mountains, Antarctica

Wagner et al. 2021

environmental conditions, and widening the geographical range via ecological niche shifts (Leavitt et al. 2015; Rolshausen et al. 2018; Vančurová et al. 2018). On the other hand, high levels of photobiont specificity are expected under conditions where ecological factors, especially (macro-) climate and/or substrate (e.g. calcareous or siliceous rock), exert a strong selective influence on lichen performance (Peksa and Skaloud 2011; Vančurová et al. 2018; Werth and Sork 2010). Additionally, genetic identity can play a significant role in shaping myco-/photobiont associations along gradients (Dal Grande et al. 2017) or may also lead to turnover zones, suggesting that photobionts are replaced by others as environmental conditions change (Rolshausen et al. 2020). An influence on the selection of Trebouxia species due to temperature combined with water availability was suggested in several studies as a key factor of photobiont selection of lichens in Antarctica (Green et al. 2011a; Wagner et al. 2020). Due to the sensitive response of lichen communities to climatic change with modified species compositions and reduced diversity (Ellis 2019; Mayer et al. 2013; Sancho et al. 2019; Sancho et al. 2017) lichen growth, abundance and diversity are expected to be negatively affected by climatic changes (Sancho et al. 2017). Consequently, lichens represent excellent bioindicators because of their sensitive responses to environmental changes (Alatalo et al. 2015; Allen and Lendemer 2016; Bassler et al. 2016; Sancho et al. 2019), and especially abundant and cosmopolitan species serve as a valuable model system to record diversity and composition along climatic gradients worldwide.

The current study focuses on the association patterns of the two main symbionts (myco- and photobiont) of the lecideoid lichen group (Ruprecht et al. 2020) that is dominant along the investigated part of the latitudinal gradient (78-85²) at the Ross Sea coast. The following objectives were addressed: (1) to assess the biodiversity and genetic identity of the symbiotic partners of lecideoid lichens using phylogenic methods; (2) to investigate how the variability of myco-/photobiont associations is related to environmental variables (elevation, temperature, precipitation) using diversity and specificity indices as well as network statistics, and (3) to identify certain myco-/photobiont associations that are representative for climatic conditions and therefore may qualify as bioindicators.

\section{Materials \& Methods}

\section{Study area and investigated lichen specimens}

The sample sites were divided in five different main areas (Fig. 1b). Area 4 (Darwin Area) was then subdivided in subareas 4a and $4 \mathrm{~b}$, considering the wide range of climate conditions within this region (Figure 1c). Site descriptions of the six regions are given in Table 1, geographical descriptions can be found at the Supplementary Table S1.

Altogether 306 lecideoid lichen specimens were collected on siliceous substrate along a latitudinal gradient $\left(78-85.5^{\circ} \mathrm{S}\right)$ of the southwest Ross Sea coast (Antarctica, Fig.1a-c). 147 samples of the genera Carbonea, Lecanora, Lecidella and Lecidea were collected at 70 different localities from the following sampling areas: Area 1, Scott Glacier/Durham Point; Area 2, Massam Glacier/Garden Spur; Area 3, Mt. Kyffin, Mt. Harcourt, The Gateway; Area 4a, Darwin Area (Diamond Hills, Brown Hills); Area 4b, Darwin Area (Bartrum Basin, Smith Valley and Lake Wellman) (Fig. 1a-c, Supplementary Table S1). To get a better coverage of the latitudinal gradient (Fig. 1a), additionally, 159 lichen samples (collected at 102 different localities) from the Area 5, McMurdo Dry Valleys (MDV), were obtained from the studies of Wagner et al. (2020) and Perez-Ortega et al. (2012), including the solely lecideoid lichen species of the genera Carbonea, Lecanora, Lecidella, Lecidea and Rhizoplaca. The entire lists of samples can be found at the Supplementary Tables S2-4. 
bioRxiv preprint doi: https://doi.org/10.1101/2021.05.26.445136; this version posted May 27, 2021. The copyright holder for this preprint (which was not certified by peer review) is the author/funder, who has granted bioRxiv a license to display the preprint in perpetuity. It is made available under aCC-BY-NC-ND 4.0 International license.

Symbiotic associations in lecideoid lichens along the Transantarctic Mountains, Antarctica

Wagner et al. 2021

Table 1. Site descriptions of the six regions defined in the present study, including range of the coordinates of the sampling sites and areas, the number of sampling sites and the BIOCLIM variables BIO10 (mean temp. of the warmest quarter) and BIO12 (annual precipitation) per area.

\begin{tabular}{|c|c|c|c|c|c|c|}
\hline & Sampling area & $\begin{array}{l}\text { Range of } \\
\text { coordinates of } \\
\text { sampling sites }\end{array}$ & $\begin{array}{c}\text { Number of } \\
\text { sampling sites }\end{array}$ & $\begin{array}{l}\text { Elevation mean } \\
\quad \text { (m. a. s. I.) }\end{array}$ & $\begin{array}{l}\text { BI010: mean } \\
\text { temperature, } \\
\text { warmest } \\
\text { quarter }\left({ }^{\circ} \mathrm{C}\right)\end{array}$ & $\begin{array}{c}\text { BI012: } \\
\text { precipitation, } \\
\text { annual mean } \\
(\mathrm{mm})\end{array}$ \\
\hline Area 1 & $\begin{array}{l}\text { Scott Glacier/ } \\
\text { Durham Point }\end{array}$ & $\begin{array}{l}\text { S } 85.54^{\circ} \\
\text { W } 151.15^{\circ}\end{array}$ & 1 & 370.00 & -7.30 & 190.00 \\
\hline Area 2 & $\begin{array}{l}\text { Massam Glacier/ } \\
\text { Garden Spur }\end{array}$ & $\begin{array}{c}\text { S } 84.54^{\circ}-84.56^{\circ} \\
\text { W } 174.91^{\circ}-175.01^{\circ}\end{array}$ & 2 & 182.92 & -6.96 & 113.00 \\
\hline Area 3 & $\begin{array}{l}\text { Mt. Kyffin, The } \\
\text { Gateway, Mt. } \\
\text { Harcourt }\end{array}$ & $\begin{array}{c}\text { S } 83.49^{\circ}-83.83^{\circ} \\
\text { E } 170.79^{\circ}-172.76^{\circ}\end{array}$ & 6 & 774.72 & -8.20 & 104.37 \\
\hline Area $4 a$ & $\begin{array}{l}\text { Darwin Area: } \\
\text { Diamond Hills, } \\
\text { Brown Hills }\end{array}$ & $\begin{array}{c}\text { S } 79.84^{\circ}-79.88^{\circ} \\
\text { E } 159.22^{\circ}-159.39^{\circ}\end{array}$ & 30 & 484.19 & -8.23 & 91.79 \\
\hline Area 4b & $\begin{array}{c}\text { Darwin Area: } \\
\text { Bartrum Basin, } \\
\text { Smith Valley, Lake } \\
\text { Wellman }\end{array}$ & $\begin{array}{c}\text { S } 79.75^{\circ}-79.95^{\circ} \\
\text { E } 156.70^{\circ}-158.67^{\circ}\end{array}$ & 31 & 726.39 & -10.18 & 69.13 \\
\hline Area 5 & $\begin{array}{l}\text { McMurdo Dry } \\
\text { Valleys }\end{array}$ & $\begin{array}{c}\text { S } 78.02^{\circ}-78.17^{\circ} \\
\text { E } 163.62^{\circ}-164.10^{\circ}\end{array}$ & 102 & 589.42 & -6.24 & 145.04 \\
\hline
\end{tabular}

All voucher specimens are stored in the herbarium of the University of Salzburg (SZU) except for samples collected by Leopoldo G. Sancho which are deposited in the MAF herbarium of the Botany Unit, Fac. Farmacia, in Madrid.

\section{DNA-amplification, primer-design and sequencing}

Total DNA was extracted from individual thalli by using the DNeasy Plant Mini Kit (Qiagen) following the manufacturer's instructions. For all samples, the internal transcribed spacer (ITS) region of the mycobionts' and photobionts' nuclear ribosomal DNA (nrITS) were sequenced and amplified. Also, additional markers were amplified: for the mycobionts the mitochondrial small subunit (mtSSU) and the low-copy protein coding marker RPB1; for the photobionts, the chloroplast-encoded intergenic spacer (psbJ-L) and part of the cytochrome oxidase subunit 2 gene (COX2). This was done using specific primers and PCR-protocols in our project framework (Ruprecht et al. 2020).

The nrlTS of the mycobiont was amplified using the primers ITS1F (Gardes and Bruns 1993), ITS4(White et al. 1990), ITS1L (Ruprecht et al. 2020) and ITS4L (Ruprecht et al. 2020). The nrlTS of the photobiont was amplified using the primers 18S-ITS unifor (Ruprecht et al. 2012a), ITS4T (Kroken and Taylor 2000), ITS1T (Kroken and Taylor 2000) and ITS4bT_mod (5'CCAAAAGGCGTCCTGCA-3'; modified, based on Ruprecht et al. (2014)). For the marker mtSSU, the primer mtSSU rev2 (Ruprecht et al. 2010) and the newly designed primers mtSSU for2 mod1 (5'-AACGGCTGAACCAGCAACTTG-3') and mtSSU rev1 (5'AGGYCATGATGACTTGTCTT-3') were used. For RPB1, gRPB1-A for (Matheny et al. 2002), fRPB1-C rev (Matheny et al. 2002) and RPB1_for_Lec (Ruprecht et al. 2020) were chosen. For the marker COX2, COXIlf2 and COXIIr (Lindgren et al. 2014) and COXII_sense (Ruprecht et al. 2020) were used, for psbJ-L, newly designed psbL_for1 (5'-GTTGAATTAAATCGTACTAGT-3') psbLsense and psbJ-antisense (Ruprecht et al. 2014) were chosen.

Unpurified PCR-products were sent to Eurofins Genomics/Germany for sequencing. 
bioRxiv preprint doi: https://doi.org/10.1101/2021.05.26.445136; this version posted May 27, 2021. The copyright holder for this preprint (which was not certified by peer review) is the author/funder, who has granted bioRxiv a license to display the preprint in perpetuity. It is made available under aCC-BY-NC-ND 4.0 International license.

Symbiotic associations in lecideoid lichens along the Transantarctic Mountains, Antarctica

Wagner et al. 2021

\section{Phylogenetic analysis}

For both symbionts, the sequences were assembled and edited using Geneious version 8.0.5 (https://www.geneious.com) and aligned with MAFFT v7.017 (Katoh et al. 2002).

Maximum likelihood analyses were calculated with IQ-TREE v1.6.12 (Nguyen et al. 2014), using the model selection algorithm ModelFinder (Kalyaanamoorthy et al. 2017). Branch supports were obtained with the implemented ultrafast bootstrap (UFBoot; Minh et al. 2013). Number of bootstrap alignments: 1000, maximum iteration: 1000, minimum correlation coefficient: 0.99 . Additionally, a SH-aLRT branch test (Guindon et al. 2010) was performed. Each branch of the resulting tree was assigned with SHaLRT as well as UFBoot supports. The branches with SH-aLRT $<80 \%$ and/ or UFboot $<95 \%$ were collapsed by adding the command -minsupnew $80 / 95$ to the script.

In order to be able to use all samples with an incomplete marker set, a multi-marker phylogeny with a reduced number of samples and, in comparison, the complete data set with the marker ITS were calculated and compared, respectively for each symbiont.

For the photobiont, the classification and labeling of the different operational taxonomical units (OTUs) followed the concepts of Muggia et al. (2020) and Ruprecht et al. (2020), using automatic barcode gap discovery (ABGD; Puillandre et al. 2012), based on the marker ITS. The threshold of $97.5 \%$ sequence similarity set by Leavitt et al. (2015) and applied by Ruprecht et al. (2020) was used to ensure clear delimitation of OTUs and sub-OTUs.

\section{Analysis of spatial distribution}

Unless stated otherwise, analysis was conducted in R (R Core Team 2020; version 3.6.3, https://www.r-project.org) using RStudio (RStudio Team 2016; version 1.1.463, https://rstudio.com); figures where produced using the R package ggplot2 (Wickham 2009) and processed using Adobe Photoshop (version 22.2.0., https://www.adobe.com).

Based on data from CHELSA (Climatologies at high resolution for the earth's land surface areas; Karger et al. 2017), the 19 BIOCLIM variables (Nix 1986) were calculated for each sample point using the $\mathrm{R}$ functions raster() and extract() of the package raster (Hijmans 2020). These variables are derived variables from the monthly minimum, maximum, mean temperature and mean precipitation values, developed for species distribution modeling and related ecological applications (Karger et al. 2017). For the analyses of this study, BIO10 (mean temperature of the warmest quarter) and BIO12 (annual precipitation) were chosen, as these two variables showed the strongest correlations with the diversity and specificity indices (see below).

For analyzing the spatial distribution of the lichen samples, alpha, beta and gamma diversity values were calculated. The concept was developed in 1960 by Whittaker (Whittaker 1960) who distinguished three aspects or levels of species diversity in natural communities: (1) alpha diversity, the species richness within a particular area, (2) beta diversity, the extent of changes in species diversity between the areas, and (3) gamma diversity, a measure of the overall diversity for the different areas within the whole region. These diversity indices were calculated separately for mycobiont species and photobiont OTUs, using the $R$ functions AlphaDiversity(), BetaDiversity() and GammaDiversity() of the package entropart (Marcon and Hérault 2015), which give reducedbias diversity values (diversity order: $q=1$ (Shannon diversity); weights: $w_{i}=n_{j} / n$ with $n_{i}$, number of samples in area $i$ and $n$, total 
bioRxiv preprint doi: https://doi.org/10.1101/2021.05.26.445136; this version posted May 27, 2021. The copyright holder for this preprint (which was not certified by peer review) is the author/funder, who has granted bioRxiv a license to display the preprint in perpetuity. It is made available under aCC-BY-NC-ND 4.0 International license.

Symbiotic associations in lecideoid lichens along the Transantarctic Mountains, Antarctica

Wagner et al. 2021

number of samples). Next, alpha diversity was analyzed for correlations with the following variables: elevation, latitude, BIO10 and BI012.

To determine whether mycobiont species or photobiont OTU community composition are related to environmental variables (elevation, BIO10 and BIO12), constrained analyses of principal coordinates were conducted, using the R function capscale() of the package vegan (Oksanen et al. 2019; distance: Bray Curtis). Prior to analysis, to standardize species composition data (convert species abundances from absolute to relative values), a Hellinger transformation was performed on the community matrix, using the $R$ function decostand() of the package vegan (Oksanen et al. 2019). The variance explained by constrained ordination was tested by a Monte Carlo permutation test, using the $R$ function anova() of the package vegan (Oksanen et al. 2019).

A Mantel test was performed to test whether the differences in mycobiont species and photobiont OTU community composition between samples are related to physical distance, using the $R$ function mantel() of the package vegan (Oksanen et al. 2019).

\section{Haplotype analysis}

In order to ensure that the entire data set could be processed, all further analyses were carried out using only complete sequences of the marker ITS for all calculations. The number of haplotypes, $h$, of the different mycobiont species and photobiont OTUs was determined using the function haplotype() of the R package pegas (Paradis 2010). Haplotype networks were computed, using the function haploNet() of the R package pegas (Paradis 2010) for mycobiont species and photobiont OTUs with $h \geq 2$ and at least one haplotype with $n \geq 3$ (Carbonea sp. 2, Lecanora fuscobrunnea, Lecidea cancriformis, Lecidella greenii, Lecidella siplei, Lecidella sp. nov2 and Rhizoplaca macleanii, as well as $T r_{-}$A02, $T r_{-}$I01 and $T r_{-}$S02). The frequencies were clustered in 10\% ranges, for example the circles of all haplotypes making up between 20-30\% have the same size. Additionally, for the most common mycobiont L. cancriformis and the photobiont OTU Tr_S02, haplotype networks based on multimarker data sets were calculated, to show that the distribution of haplotypes remains congruent.

\section{Diversity and specificity indices of mycobiont species and photobiont OTUs}

The haplotype as well as the nucleotide diversity was calculated for each identified mycobiont and photobiont species with more than one sample, using the functions hap.div() and nuc.div() of the R package pegas (Paradis 2010), respectively. The haplotype diversity, $H d$, represents the probability that two randomly chosen haplotypes are different (Nei 1987), the nucleotide diversity, $\pi$, gives the average number of nucleotide differences per site between two randomly chosen DNA sequences (Nei and Li 1979). Additionally, the ratio of the number of haplotypes $h$ divided by the number of samples $N$ was calculated.

Furthermore, different metrics for quantifying the phylogenetic species diversity and the specificity of the mycobiont species and photobiont OTUs towards their interaction partners were calculated. Those included the indices NRI (Net relatedness index), PSR (Phylogenetic species richness) and the Pielou evenness index J'. (Note: to make interpretation similar to the other metrics, for further analyses 1 - J' instead of J' was used.) An overview of these diversity metrics is given in Supplementary Table S5.

In order to analyze the correlation of these diversity metrics with environment, for every mycobiont species and photobiont OTU with $n \geq 10$ (Carbonea sp. 2, C. vorticosa, Lecanora fuscobrunnea, Lecidea cancriformis, L. polypycnidophora, Lecidella greenii, 
bioRxiv preprint doi: https://doi.org/10.1101/2021.05.26.445136; this version posted May 27, 2021. The copyright holder for this preprint (which

was not certified by peer review) is the author/funder, who has granted bioRxiv a license to display the preprint in perpetuity. It is made available under aCC-BY-NC-ND 4.0 International license.

Symbiotic associations in lecideoid lichens along the Transantarctic Mountains, Antarctica

Wagner et al. 2021

L. siplei, Rhizoplaca macleanii and Trebouxia OTUs Tr_A02, Tr_101, Tr_S02, Tr_S15, Tr_S18) the mean values of the sample locations of the following variables were calculated: elevation, latitude, BIO10 and BIO12.

\section{Analysis of mycobiont - photobiont associations}

To analyze the associations between mycobiont species and photobiont OTUs, bipartite networks were computed, using the $R$ function plotweb() of the package bipartite (Dormann et al. 2008). This was done for each area separately. Additionally, for each bipartite network, the index $\mathrm{H}_{2}{ }^{\prime}$ was calculated. $\mathrm{H}_{2}{ }^{\prime}$ is derived from Shannon entropy and characterizes the degree of complementary specialization of partitioning among the two parties of the network. It ranges from 0 for the most generalized to 1 for the most specialized case und was computed using the R functions H2fun() of the package bipartite (Dormann et al. 2008).

Usually, in the context of bipartite networks, also the d'value (specialization index) is computed. This value was originally defined for pollination networks and calculates how strongly a species deviates from a random sampling of interacting partners available (Dormann 2011). Thus, in the case of lichens, the $d^{\prime}$ 'value of a mycobiont species is based on the assumption that for every site of a sampling area, the whole set of photobiont OTUs basically is available. As this is not true for this study, this index was not included.

\section{Results}

\section{Phylogenetic analysis}

For both the mycobiont and photobiont molecular phylogenies from multi-locus sequence data (nrlTS, mtSSU and RPB1 for the mycobiont (140 samples) and nrlTS, psbJ-L and COX2 for the photobiont (139 samples) were inferred (Supplementary Fig. S1 and S3). Additionally, phylogenies based solely on the marker nrlTS were calculated (Supplementary Fig. S2 and S4), to include samples where the additional markers were not available. Both analyses include only accessions from the study sites (Fig. 1, Table 1). The phylogenies based on the multi-locus data were congruent to the clades of the phylogenies based on the marker nrlTS. Thus, in the following, the focus will be only on the latter.

Mycobiont: The final data matrix for the phylogeny based on the marker nrlTS comprised 306 single sequences with a length of $550 \mathrm{bp}$. It included sequences of the families Lecanoraceae and Lecideaceae. The phylogenetic tree was midpoint rooted and shows a total of 19 strongly supported clades on species level, assigned to five genera. The backbone is not supported and therefore the topology will not be discussed. All genera are clearly assigned to their family level and are strongly supported. Only Lecanora physicella forms an extra clade as sister to the families Lecideaceae and Lecanoraeae, which is not the case at the multimarker phylogeny. L. physciella has still an uncertain status, because of morphological similarities to both sister families (Ruprecht et al. 2012b). The clade of the genus Lecidea revealed seven species (L. andersonii, L. polypycnidophora, L. UCR1, $L$. sp. 5, L. lapicida, L. cancriformis and L. sp. 6), Lecanora five species (L. physciella, L. sp. 2, L. fuscobrunnea, L. cf. mons-nivis, L. sp. 3), Carbonea three species (C. sp. URm1, C. vorticosa, C. sp. 2), and Lecidella three species (L. greenii, L. siplei, L. sp. nov2). The samples allocated to the genus Rhizoplaca were monospecific ( $R$. macleanii). The taxonomical assignment of the obtained sequences were based on the studies of Ruprecht et al. (2020) and Wagner et al. (2020). 
bioRxiv preprint doi: https://doi.org/10.1101/2021.05.26.445136; this version posted May 27, 2021. The copyright holder for this preprint (which was not certified by peer review) is the author/funder, who has granted bioRxiv a license to display the preprint in perpetuity. It is made available under aCC-BY-NC-ND 4.0 International license.

Symbiotic associations in lecideoid lichens along the Transantarctic Mountains, Antarctica

Wagner et al. 2021

Photobiont: The final data matrix for the phylogeny based on the marker nrlTS comprised 281 single sequences with a length of $584 \mathrm{bp}$. The phylogenetic tree was midpoint rooted and shows six strongly-supported clades, assigned to seven different OTU levels (Puillandre et al. 2012), using the concept of Muggia et al. (2020) and Ruprecht et al. (2020). The backbone is not supported and therefore the topology will not be discussed. All of the OTUs belong to the genus Trebouxia (clades A, I, S), comprising Tr_A02, Tr_A04a, Tr_101,Tr_I17, Tr_S02, Tr_S15 and Tr_S18. Photobiont sequences taken from Perez-Ortega et al. (2012), which were labelled only with numbers, were renamed to assign them to the appropriate OTUs (Ruprecht et al. 2020).

\section{Analysis of spatial distribution}

In general, the most common mycobionts were Lecidea cancriformis (94 of the 306 samples), Rhizoplaca macleanii (51 samples) and Lecidella greenii (37 samples), followed by Carbonea sp. 2 (13 samples), C. vorticosa (11 samples), Lecidea polypycnidophora (10 samples) and Lecidella siplei (10 samples; see Supplementary Fig. S5). Nine mycobiont species were found exclusively in area 5 (MDV, $78^{\circ}$ S): Carbonea vorticosa, Lecanora cf. mons-nivis, L. sp. 2, Lecidea lapicida, L. polypycnidophora, L. sp. 5, L. sp. 6, L. UCR1 and Rhizoplaca macleanii. On the other hand, only the mycobiont species Lecidea cancriformis was found in all the six areas; Lecanora fuscobrunnea was present in all the areas with the exception of area 2.

The most common photobiont OTUs were Tr_A02 (165 of the 281 samples) and Tr_S02 (59 samples), both of them occurring in all the six different areas, followed by $T r_{-}$S18 (32 samples), Tr_S15 (10 samples, confined to area 5) and Tr_101 (10 samples). However, of the 149 photobiont samples of area 5, 134 (89,93\%) were assigned to Tr_A02. This percentage is much higher than in the other areas (area 1: 44,44\%, area 2: 69,23\%, area 3: 21,74\%, area 4a: 7,69\%, area $4 b: 6,67 \%$ ), even if those samples with mycobionts occurring exclusively in area 5 (see above) were excluded (76.56 \% of the 64 remaining samples are assigned to Tr_A02).

Table 2. Number of lichen samples, number of identified mycobiont species and photobiont OTUs, as well as alpha, beta and gamma diversity values of mycobiont species/ photobiont OTUs for the different areas.

\begin{tabular}{|c|c|c|c|c|c|c|c|c|c|}
\hline \multirow[b]{2}{*}{ Area } & \multirow[b]{2}{*}{$\begin{array}{l}\text { Number } \\
\text { of lichen } \\
\text { samples }\end{array}$} & \multicolumn{4}{|c|}{ Mycobiont species } & \multicolumn{4}{|c|}{ Photobiont OTUs } \\
\hline & & $\begin{array}{l}\text { Number of } \\
\text { identified } \\
\text { species }\end{array}$ & $\begin{array}{c}\text { Alpha } \\
\text { diversity }\end{array}$ & $\begin{array}{c}\text { Beta } \\
\text { diversity }\end{array}$ & $\begin{array}{l}\text { Gamma } \\
\text { diversity }\end{array}$ & $\begin{array}{l}\text { Number of } \\
\text { identified } \\
\text { OTUs }\end{array}$ & $\begin{array}{c}\text { Alpha } \\
\text { diversity }\end{array}$ & $\begin{array}{c}\text { Beta } \\
\text { diversity }\end{array}$ & $\begin{array}{l}\text { Gamma } \\
\text { diversity }\end{array}$ \\
\hline 1 & 28 & 7 & 5.23 & & & 3 & 2.28 & & \\
\hline 2 & 13 & 5 & 5.48 & & & 3 & 2.20 & & \\
\hline 3 & 27 & 7 & 5.99 & & & 5 & 3.70 & & \\
\hline $4 a$ & 48 & 6 & 3.55 & 1.69 & 9.92 & 6 & 4.06 & 1.64 & 3.35 \\
\hline $4 b$ & 31 & 2 & 1.88 & & & 4 & 2.36 & & \\
\hline 5 & 159 & 16 & 8.93 & & & 4 & 1.50 & & \\
\hline
\end{tabular}

The alpha, beta and gamma diversity values are given in Table 2. For the mycobionts, the value of alpha diversity (species richness within a particular area) was the highest in area 5 (8.93) and the lowest in area $4 \mathrm{~b}$ (1.88). In contrast, for the photobionts, the lowest alpha diversity value was found in area $5(1.50)$ and the highest in area $4 a(4.06)$. Thus, referring to this, area 5 plays a remarkable role: compared to the other areas, it shows the highest richness of mycobiont species on the one hand and the lowest richness of photobiont OTUs on the other hand. 
bioRxiv preprint doi: https://doi.org/10.1101/2021.05.26.445136; this version posted May 27, 2021. The copyright holder for this preprint (which was not certified by peer review) is the author/funder, who has granted bioRxiv a license to display the preprint in perpetuity. It is made available under aCC-BY-NC-ND 4.0 International license.

Symbiotic associations in lecideoid lichens along the Transantarctic Mountains, Antarctica

Wagner et al. 2021

The beta diversity values (extent in changes of species diversity between the areas) for mycobiont species and photobiont OTUs are quite similar (1.69 and 1.64, respectively). This is in contrast to gamma diversity values: the overall diversity for the different areas within the whole region is much higher for mycobiont species (9.92) than for photobiont OTUs (3.35).

\section{Influence of environmental factors (elevation, precipitation and temperature)}

First, the proportion of Tr_A02 samples was significantly correlated to BI010 means of the areas $(R=0.87, p=0.022$; see Supplementary Fig. S6): the higher the temperature mean values of the warmest quarter of an area, the higher the proportion of samples containing photobionts that are assigned to the OTU Tr_A02.

The alpha diversity values of mycobiont species significantly positively correlated with $\mathrm{BIO10}(R=0.88, p=0.021$; see Supplementary Fig. S7): the higher the temperature mean values of the warmest quarter, the higher the mycobiont diversity within this particular area.

Furthermore, the differences in mycobiont species community composition were significantly related to $\mathrm{BIO} 10$ (constrained principal coordinate analysis: $F=14.7137, p=0.001$, see Supplementary Fig. $S 8), B I 012(F=2.7535, p=0.012)$, elevation $(F=2.5108$, $p=0.025$ ) and the geographic separation of the samples (Mantel statistic $r=0.1288, p=0.0002$ ).

The differences in community composition of photobiont OTUs were related significantly to BIO10 (constrained principal coordinate analysis: $F=48.5952, p=0.001$, see Supplementary Fig. $S 9), B I 012(F=4.4848, p=0.008)$, elevation $(F=6.8608, p=0.002)$, and physical distance (Mantel statistic $r=0.4472, p=0.0001$ ).

\section{Haplotype analysis}

Haplotype networks were computed for the mycobiont species and photobiont OTUs with $\mathrm{h} \geq 2$ and at least one haplotype with $n \geq 3$ (Carbonea sp. 2, Lecanora fuscobrunnea, Lecidea cancriformis, Lecidella greenii, L. siplei, L. sp. nov2 and Rhizoplaca macleanii, as well as Tr_A02, Tr_101 and Tr_S02), in both cases based on nrlTS sequence data (Figs. 2 \& 3). The samples of Carbonea vorticosa (11) were all assigned to a single haplotype, which was also true for Lecidea polypycnidophora (10 samples), Tr_S15 (10 samples) and Tr_S18 (32 samples). Figure 3b and c illustrate the subdivision of Tr_101 (Muggia et al. 2020) into Tr_101j (Leavitt et al. 2015; Ruprecht et al. 2020) and Tr_101k (in this study), and the subdivision of Tr_S02 into Tr_S02 (Leavitt et al. 2015), and Tr_S02b and Tr_S02c (Ruprecht et al. 2020).

The haplotype networks include pie charts showing the occurrence of the different haplotypes within the different areas. All haplotypes of Rhizoplaca macleanii are restricted to area 5 , as well as Lecidella greenii mainly to area 5 and areas $1 \& 4 a$ and Lecidella sp. 2 to areas $2 \& 3$. However, all other species do not suggest a spatial pattern with different haplotypes being specific for different areas. Moreover, the distribution turned out to be rather unspecific, with a great part of the haplotypes found in multiple areas. For the sake of completeness, additionally, haplotype networks based on multi-locus sequence data were computed for the most abundant mycobiont species and photobiont OTU with multi-locus data available (Lecidea cancriformis and Tr_S02). Not 
bioRxiv preprint doi: https://doi.org/10.1101/2021.05.26.445136; this version posted May 27, 2021. The copyright holder for this preprint (which was not certified by peer review) is the author/funder, who has granted bioRxiv a license to display the preprint in perpetuity. It is made available under aCC-BY-NC-ND 4.0 International license.

Symbiotic associations in lecideoid lichens along the Transantarctic Mountains, Antarctica

Wagner et al. 2021

surprisingly, those networks show a greater number of different haplotypes, but they also do not allow conclusions concerning spatial patterns of area specific haplotypes (see Supplementary Fig. S10).

a

Carbonea sp. 2

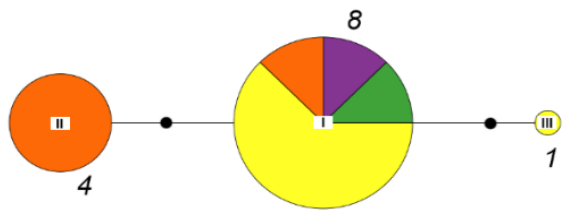

c

Lecidea cancriformis

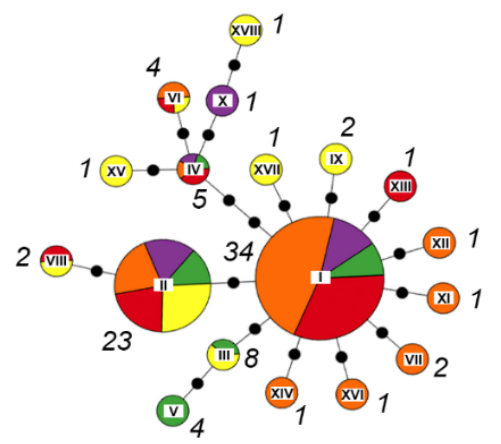

e

Lecidella siplei

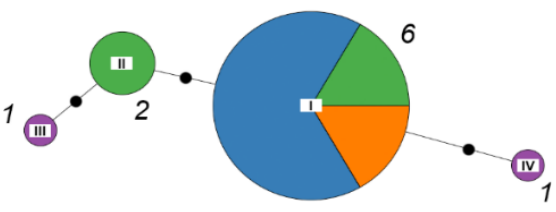

g

Rhizoplaca macleanii

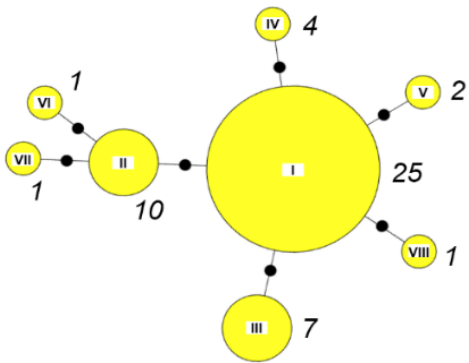

b Lecanora fuscobrunnea

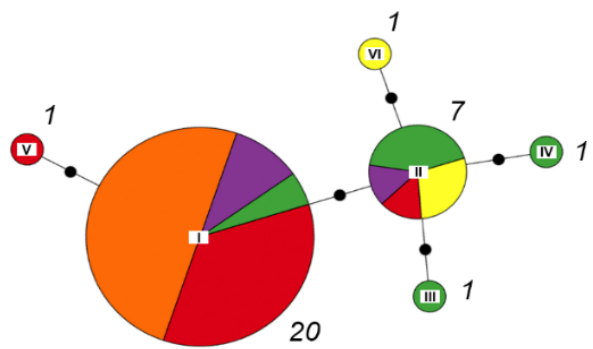

d Lecidella greenii

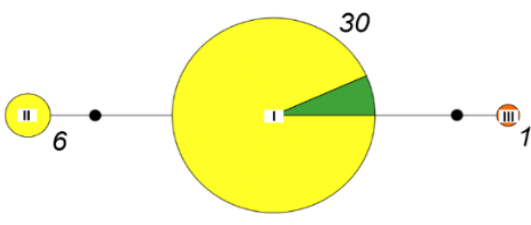

f

Lecidella sp. nov2

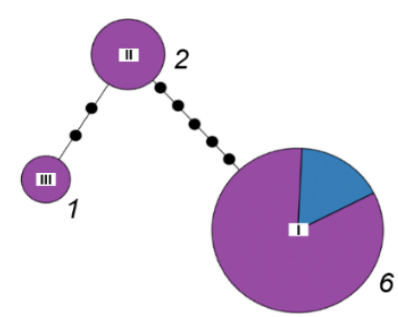

Area 1

Area 2

Area 3

Area $4 a$

Area $4 b$

Area 5

Figure 2. Haplotype networks of mycobiont species with $h \geq 2$ and at least one haplotype with $n \geq 3$, showing the spatial distribution within the different areas. Based on nrlTS data. (a) Carbonea sp. 2, (b) Lecanora fuscobrunnea, (c) Lecidea cancriformis, (d) Lecidella greenii, (e) Lecidella siplei, (f) Lecidella sp. nov2, (g) Rhizoplaca macleanii. Roman numerals at the center of the pie charts refer to the haplotype IDs; the italic numbers next to the pie charts give the total number of samples per haplotype. The circle sizes reflect relative frequency within the species; the frequencies were clustered in ten (e.g. the circles of all haplotypes making up between 20-30 \% have the same size). Note: only complete sequences were included. 
bioRxiv preprint doi: https://doi.org/10.1101/2021.05.26.445136; this version posted May 27, 2021. The copyright holder for this preprint (which was not certified by peer review) is the author/funder, who has granted bioRxiv a license to display the preprint in perpetuity. It is made available under aCC-BY-NC-ND 4.0 International license.

a

Trebouxia OTU A02

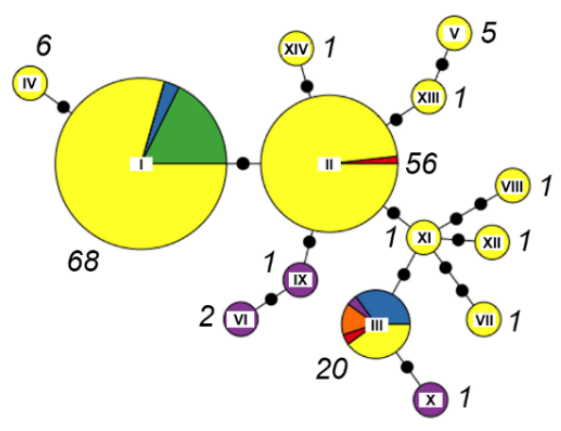

c

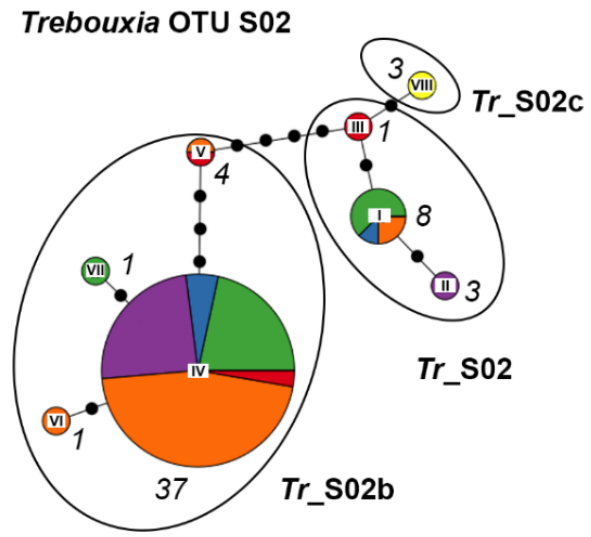

b

Trebouxia OTU 101

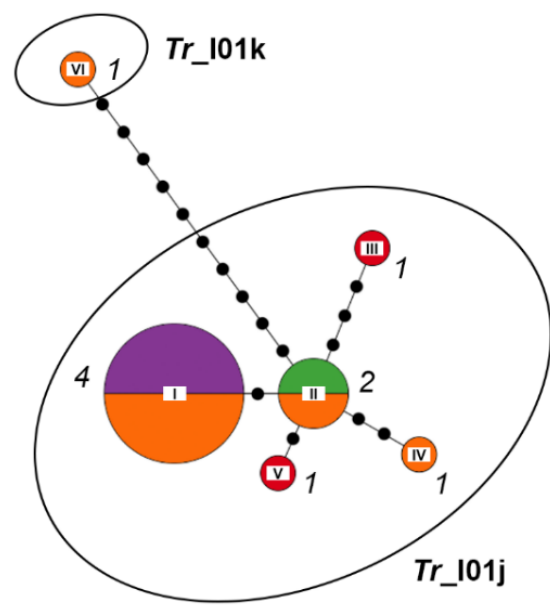

Area 1

Area 2

Area 3

Area 4a

Area 4b

Area 5

Figure 3. Haplotype networks of photobiont OTUs with $h \geq 2$ and at least one haplotype with $n \geq 3$, showing the spatial distribution within the different areas. Based on nrITS data. (a) Tr_A02, (b) Tr_101, (c) Tr_S02. Roman numerals at the center of the pie charts refer to the haplotype IDs; the italic numbers next to the pie charts give the total number of samples per haplotype. The circle sizes reflect relative frequency within the species; the frequencies were clustered in ten (e.g. the circles of all haplotypes making up between 20-30\% have the same size). Note: only complete sequences were included.

\section{Diversity and specificity indices of mycobiont species and photobiont OTUs}

The diversity and specificity indices for the different mycobiont species and photobiont OTUs are given in Supplementary Table S6.

For the sample locations of mycobiont species with $n \geq 10$, BIO10 was strongly correlated to the specificity indices NRI (net relatedness index) and significantly correlated to PSR (phylogenetic species richness) and 1 - J' (Pielou evenness index). BI012 was significantly correlated to NRI, PSR and $1-J$ '. Figure 4 illustrates these correlations: the higher the $\mathrm{BIO} 10$ and $\mathrm{BIO} 12$ mean values, the higher the NRI (phylogenetic clustering of the photobiont symbiosis partners), the lower the PSR (increased phylogenetically relatedness of photobiont symbiosis partners) and the higher $1-J^{\prime}$ (less numerically evenness of the photobiont symbiosis partners). Thus, for the mean values of the sample locations of a mycobiont species, a comparatively high temperature of the warmest quarter and high annual precipitation occurs with associated photobionts that are phylogenetically clustered and closer related to each other. The lowest values of NRI and the highest values of PSR were developed by Lecidea cancriformis and 
bioRxiv preprint doi: https://doi.org/10.1101/2021.05.26.445136; this version posted May 27, 2021. The copyright holder for this preprint (which was not certified by peer review) is the author/funder, who has granted bioRxiv a license to display the preprint in perpetuity. It is made available under aCC-BY-NC-ND 4.0 International license.

Symbiotic associations in lecideoid lichens along the Transantarctic Mountains, Antarctica

Wagner et al. 2021

Lecanora fuscobrunnea, which also showed the lowest $\mathrm{BIO} 10$ and $\mathrm{BIO} 12$ mean values at their sample sites. On the contrary, the highest values of NRI and PSR were developed by Rhizoplaca macleanii, which also had the highest BIO10 and BIO12 means.

\begin{tabular}{lll} 
Mycobiont species & \\
$\square$ Carbonea sp. 2 & $\square$ Lecidea cancriformis & $\square$ Lecidella siplei \\
$\square$ Carbonea vorticosa & $\square$ Lecidea polypycnidophora \\
$\square$ Lecanora fuscobrunnea & $\square$ Lecidella greenii \\
\hline
\end{tabular}
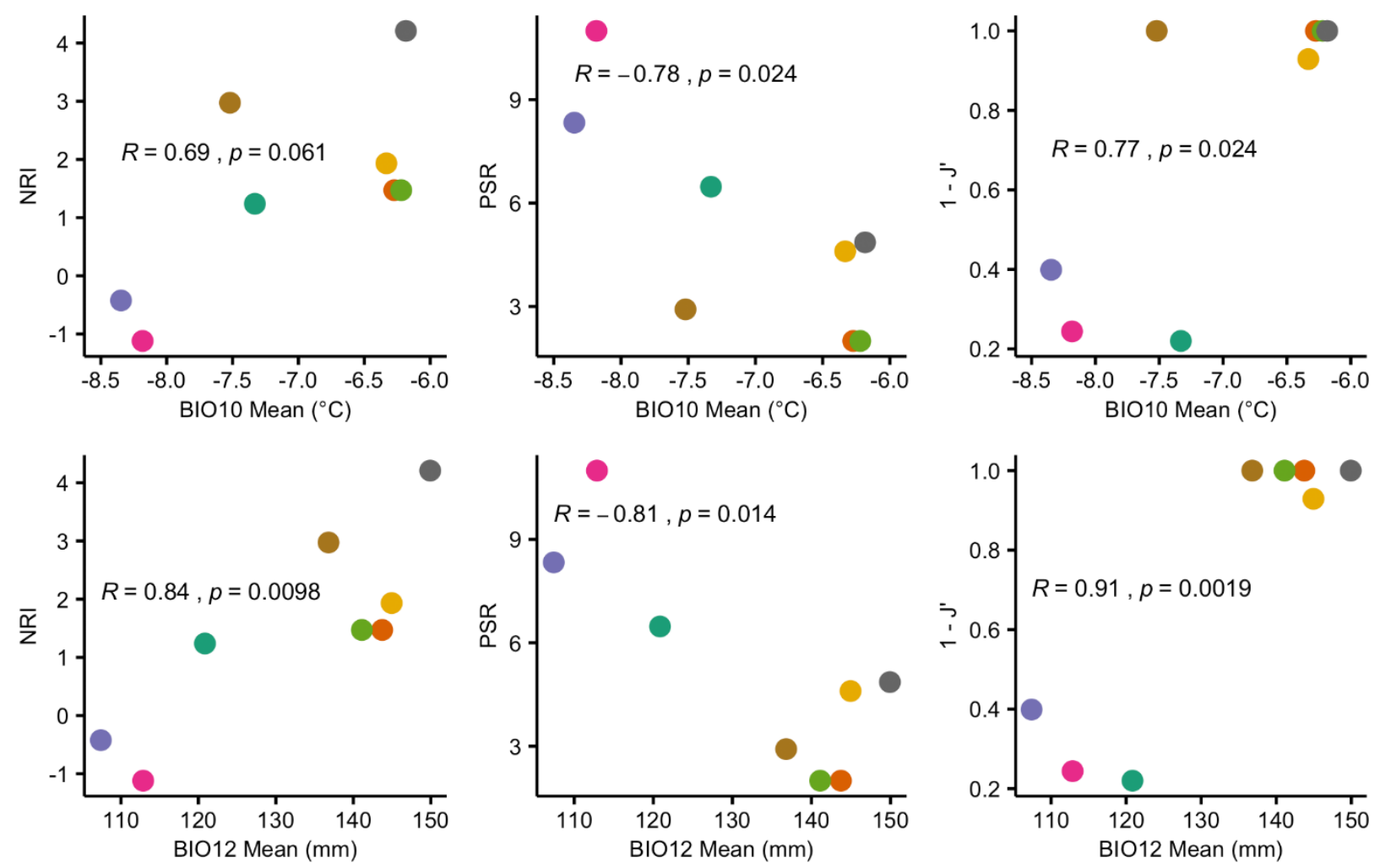

Figure 4. Correlation plots. Specificity indices NRI (net relatedness index), PSR (phylogenetic species richness and $1-J$ '(Pielou evenness index) against mean values of BIO10 (mean temperature of warmest quarter) and BIO12 (annual precipitation) for mycobiont species with $n \geq 10$.

For the sample locations of photobiont OTUs with $n \geq 10$, elevation significantly negatively correlated with $h$ (number of haplotypes) and $H d$ (haplotype diversity): the higher the mean elevation of sample sites, the lower the number of haplotypes and the lower the probability that two randomly chosen haplotypes are different (Fig. 5). The highest values of $h$ and $H d$ were for Tr_A02, Tr_I01 and $T r \_$S02, which occurred at sample sites with comparatively low elevations. In contrast, $T r \_S 15$ and $T r \_S 18$ occurred at very high elevations and showed very low values of $h$ and $H d$. 
bioRxiv preprint doi: https://doi.org/10.1101/2021.05.26.445136; this version posted May 27, 2021. The copyright holder for this preprint (which was not certified by peer review) is the author/funder, who has granted bioRxiv a license to display the preprint in perpetuity. It is made available under aCC-BY-NC-ND 4.0 International license.

\section{Photobiont OTU \\ $\square T r_{-}$A02 $\square$ Tr_101 $\square$ Tr_S02 $\square$ Tr_S15 $\square \quad$ Tr_S18}
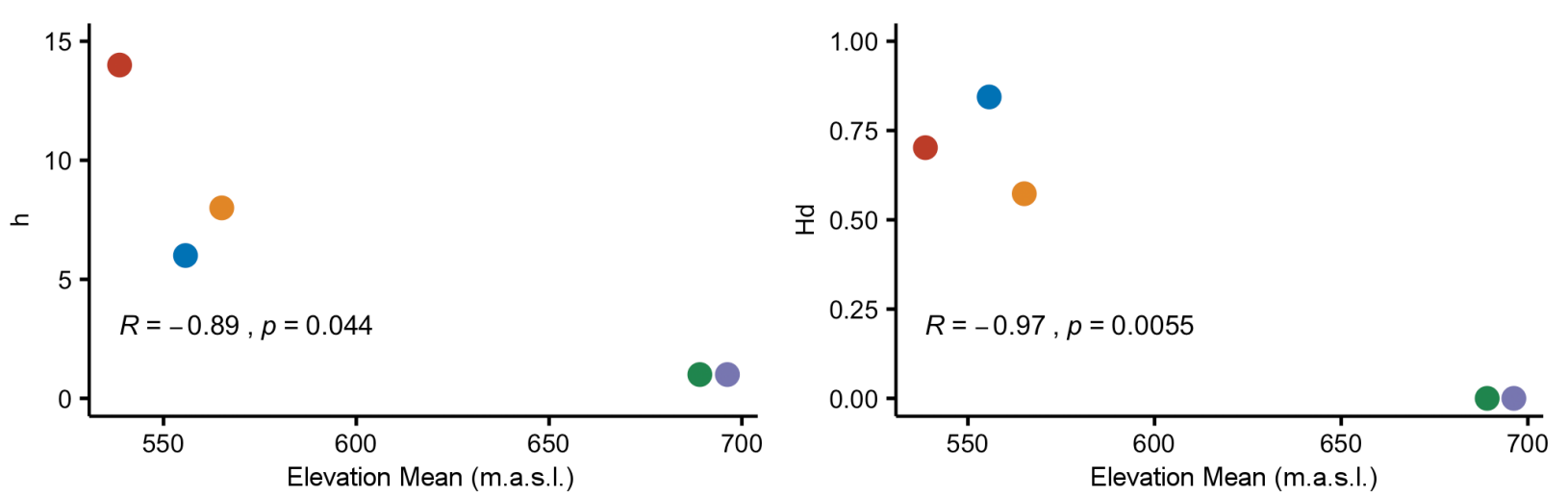

Figure 5. Correlation plots. Diversity indices $h$ (number of haplotypes) and $H d$ (haplotype diversity) against mean elevation of sample sites for photobiont OTUs with $n \geq 10$.

\section{Analysis of mycobiont-photobiont associations}

Bipartite networks were calculated for all associations between mycobiont species (lower level) and the respective photobiont OTUs (higher level) for all areas (Fig. 6). The $\mathrm{H}_{2}$ ' value (overall level of complementary specialization of all interacting species) was highest in area 2 (0.921), indicating a network with mostly specialized interactions: within this network, with the exception of Lecidea andersonii, the mycobiont species are associated exclusively with one single photobiont OTU. The second highest $\mathrm{H}_{2}$ ' value was developed by area $4 \mathrm{a}(0.710)$; in contrast, area 4 a showed the lowest $H_{2}$ ' value $(0.260)$, with the most abundant mycobiont species Lecidea cancriformis showing associations with five different photobiont OTUs. The $\mathrm{H}_{2}$ ' values of area 1 , area 3 and area 5 indicate medium specification.

In addition, the bipartite networks illustrate the different occurrence of mycobiont species and photobiont OTUs within the different areas: For example, in area 1 (and area 2), five (seven) different mycobiont species are associated with only three different photobiont OTUs. In contrast, in area 4b, only two different mycobiont species are associated with four different photobiont OTUs. In area 5 , the number of associated photobiont OTUs is also four, but those four OTUs are associated with 16 different mycobiont species.

The network matrix giving all the associations between the mycobiont species and photobiont OTUs is presented in Supplementary Table S7. 
bioRxiv preprint doi: https://doi.org/10.1101/2021.05.26.445136; this version posted May 27, 2021. The copyright holder for this preprint (which was not certified by peer review) is the author/funder, who has granted bioRxiv a license to display the preprint in perpetuity. It is made available under aCC-BY-NC-ND 4.0 International license.

Area 1

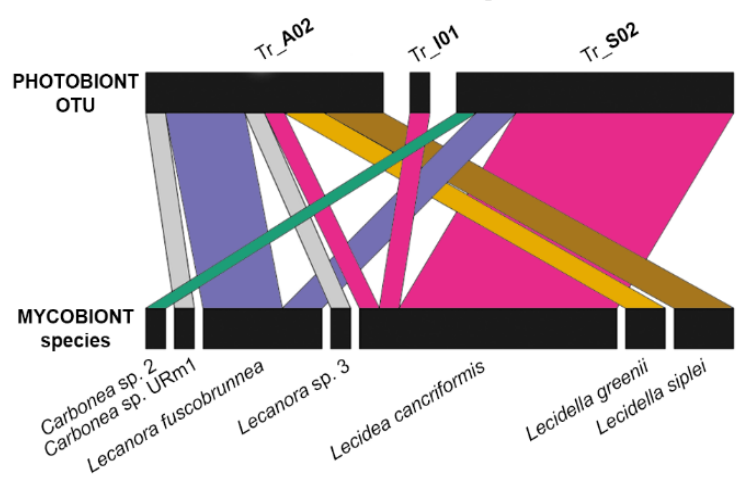

Area 3

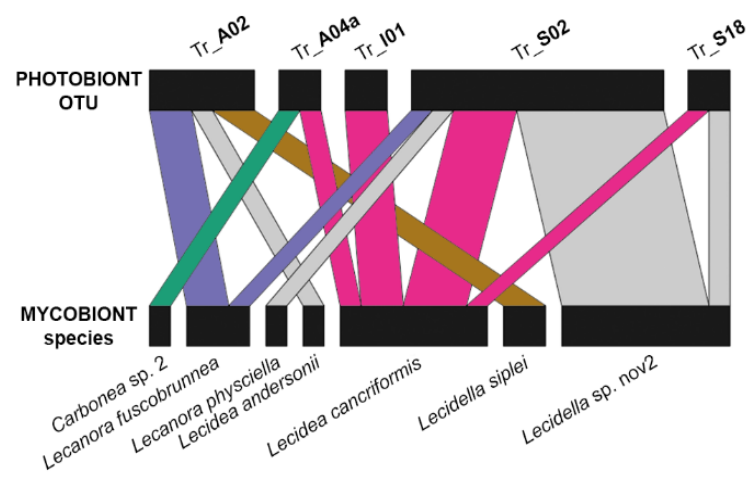

Area $4 b$

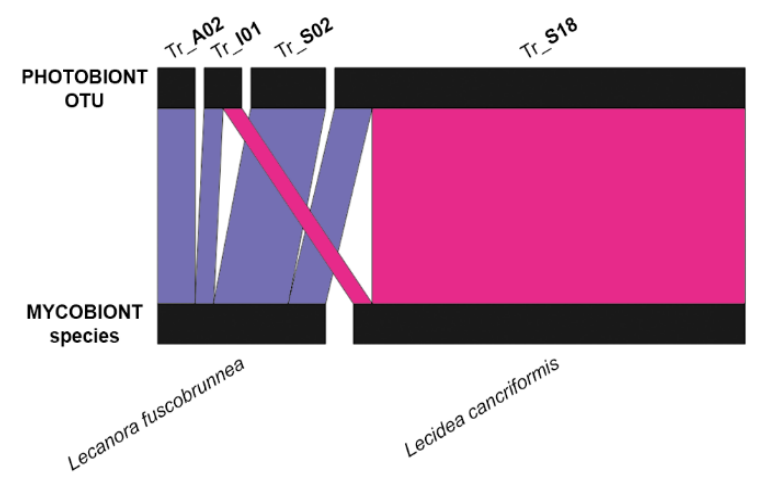

Area 2

$H_{2}{ }^{\prime}=0.921$

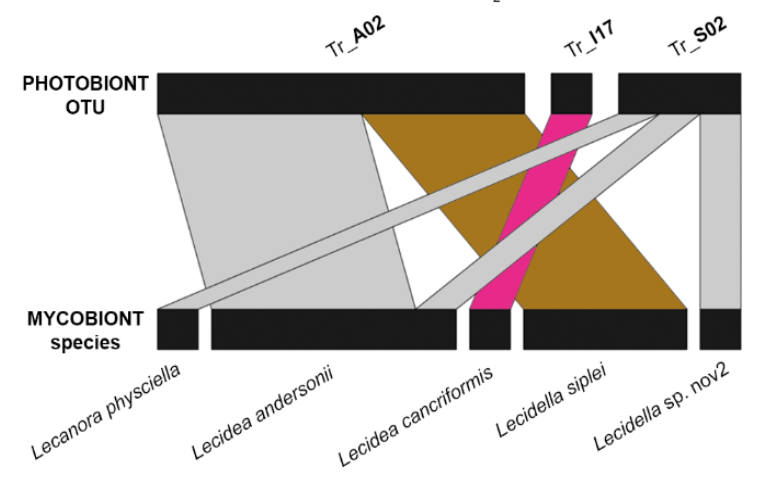

Area 4a

$H_{2}=0.260$

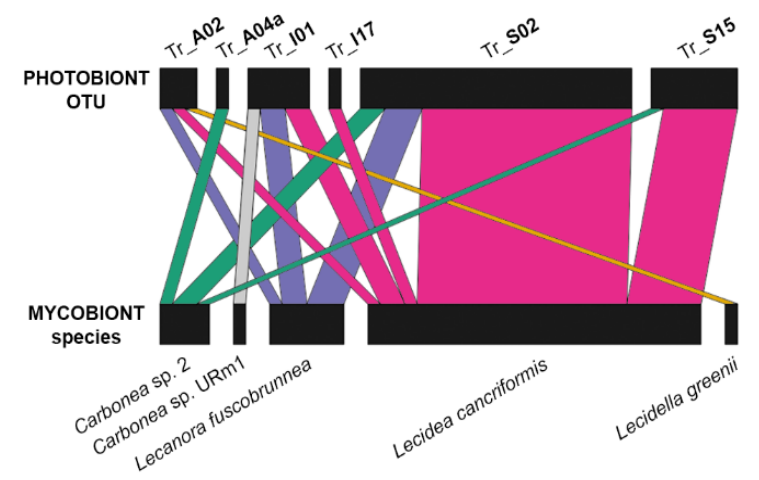

Area 5

$H_{2}=0.449$

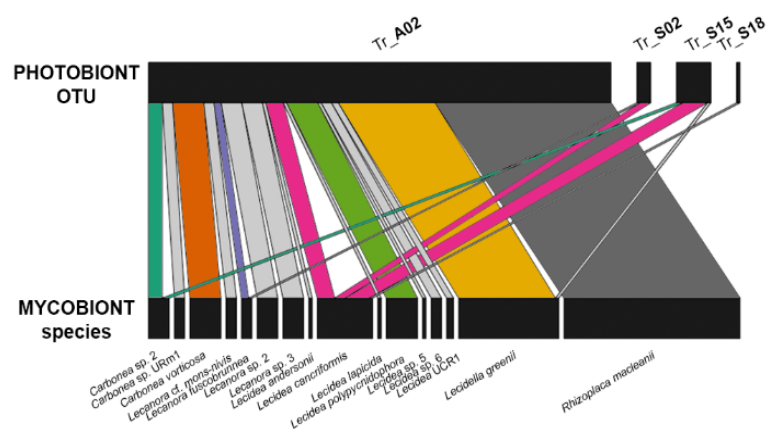

Figure 6. Bipartite networks showing the associations between mycobiont species and photobiont OTUs for the different areas. Rectangles represent species, and the width is proportional to the number of samples. Associated species are linked by lines whose width is proportional to the number of associations. 
bioRxiv preprint doi: https://doi.org/10.1101/2021.05.26.445136; this version posted May 27, 2021. The copyright holder for this preprint (which was not certified by peer review) is the author/funder, who has granted bioRxiv a license to display the preprint in perpetuity. It is made available under aCC-BY-NC-ND 4.0 International license.

Symbiotic associations in lecideoid lichens along the Transantarctic Mountains, Antarctica

Wagner et al. 2021

\section{Discussion}

The present study investigated the diversity of lecideoid lichens at six different sample areas along a latitudinal gradient $\left(78^{\circ} \mathrm{S}-\right.$ $85.5^{\circ} \mathrm{S}$ ) along the Transantarctic Mountains, Ross Sea region, at continental Antarctica. The distribution of the different mycobiont species and photobiont OTUs differed considerably between the six sample areas, which is expressed in alpha diversity values (species richness; Supplementary Figure S7). The extreme climate (lowest mean temperatures of the warmest quarter, lowest precipitation) at the areas $4 \mathrm{a} \& \mathrm{~b}$ (Darwin Area, $\sim 79.8^{\circ} \mathrm{S}$ ) was reflected in the lowest species richness of mycobionts, and comparatively high species richness of photobiont OTUs. On the other hand, in the climatically mildest area 5 (McMurdo Dry Valleys, $78^{\circ} \mathrm{S}$, highest mean temperature, second highest precipitation), the highest species richness of mycobionts and the lowest species richness of photobiont OTUs was found. The number of different photobiont OTUs identified per area is comparatively at a similar level (varying between three and six different groups, Table 2), which is remarkable when considering the great differences in sample sizes (varying between 13 samples (area 2) and 159 samples (area 5), Table 2).

These results are largely consistent with the findings of Colesie et al. (2014), who previously reported that macroclimatic conditions along the latitudinal gradient are not linear. The area at Diamond Hill $\left(79.9^{\circ} \mathrm{S}\right.$, part of area $4 \mathrm{a}$, Darwin area, Fig. $\left.1 \mathrm{c}\right)$ addressed in Colesie et al. 2014 showed the lowest species diversity along the latitudinal gradient, which was at least confirmed for area 4b in the current study. Areas $4 a$ and especially $4 b$ are characterized by the harshest climatic conditions such as very low humidity and temperatures, and species numbers in relation to the number of samples are also lowest there; the two generalist species Lecidea cancriformis and Lecanora fuscobrunnea are dominant. Milder areas, further south (83.5-85.5 $\mathrm{S})$, the McMurdo Dry Valleys $\left(78^{\circ} \mathrm{S}\right)$, allow a higher species diversity (Green et al. 2011b; Perez-Ortega et al. 2012). The higher diversity at the southern sites, particularly Mt. Kyffin, appears in part to be due to the occurrence of relic species (Green et al. 2011b). However, Colesie et al. (2014) suggested that physical barriers could be the reason for the low diversity in the Darwin area, but the unspecified haplotype distribution of the widespread species suggest that this is not the case. Since the substrate at all sites is siliceous and there are no other obvious limiting factors, the most likely reason for the limited occurrence of certain species is primarily dependent on abiotic factors, in particular, the environmental conditions caused by geography and macroclimate (Dal Grande et al. 2018).

The uniformity of photobiont OTUs in area 5 is mainly due to a strong dominance $(89.93 \%)$ of the OTU Trebouxia A02 which occurred in all the six sampling areas. The proportion of photobiont samples assigned to Tr_A02 was significantly correlated to the mean value of $\mathrm{BIO10} \mathrm{(mean} \mathrm{temperature} \mathrm{of} \mathrm{the} \mathrm{warmest} \mathrm{month)} \mathrm{of} \mathrm{the} \mathrm{areas.} \mathrm{Thus,} \mathrm{higher} \mathrm{temperatures} \mathrm{are} \mathrm{related} \mathrm{to} \mathrm{a} \mathrm{higher}$ relative abundance of $\operatorname{Tr}_{-}$A02, and colder temperatures to a higher relative abundance of other Trebouxia OTUs. This result is in basic agreement with the previous study of Wagner et al. (2020). The community composition of both, mycobiont species as well as photobiont OTUs is significantly related to elevation, $\mathrm{BIO} 10$ and $\mathrm{BIO12}$ (annual precipitation). Thus, as sampling sites become more dissimilar in terms of elevation, $\mathrm{BIO} 10$ or $\mathrm{BIO} 12$, they also become more dissimilar in terms of community composition. These findings are partially supported by Rolshausen et al. (2020) who surveyed Trebouxia communities in temperate climates, suggesting that photobionts are replaced by others as environmental conditions change. In addition, significant correlations emerged between the composition of mycobiont and photobiont OTU communities and the geographic separation of the samples: The further the sampling sites are spatially separated, the more dissimilar the corresponding communities become, which is in agreement with Fernandez-Mendoza et al. (2011). 
bioRxiv preprint doi: https://doi.org/10.1101/2021.05.26.445136; this version posted May 27, 2021. The copyright holder for this preprint (which was not certified by peer review) is the author/funder, who has granted bioRxiv a license to display the preprint in perpetuity. It is made available under aCC-BY-NC-ND 4.0 International license.

Symbiotic associations in lecideoid lichens along the Transantarctic Mountains, Antarctica

Wagner et al. 2021

Furthermore, the specificity of mycobiont species towards their photobiont partners was shown to be related to environmental variables; these findings are partially in agreement with the studies of Peksa and Skaloud (2011), Singh et al. (2017) and Rolshausen et al. (2018), who reported climate as well as substrate a selective pressure in terms of increased specificity of mycobiont-photobiont interactions. However, the current study has shown that a higher value of BIO10 correlated with a higher phylogenetic clustering of the symbiotic partners of a single mycobiont species (higher $1-J$ ' and NRI values) and a closer phylogenetic relatedness of these photobionts (lower PSR values). Similarly, the specificity of mycobiont species towards their photobiont symbiosis partners also correlated with BI012 mean values: A higher value of BI012 is related to higher values of $1-J$ ' and $N R I$ and to lower values of PSR. Consequently, the mycobiont species with $n \geq 10$ showing the highest $\mathrm{BIO} 10$ and $\mathrm{BIO} 12$ mean values at its sample locations (Rhizoplaca macleanii) also had the highest value of $N R I$ and a rather low value of $P S R$, as it was solely associated with $\operatorname{Tr}$ A A02. On the other hand, the two mycobiont species with $n \geq 10$ showing the lowest mean values of $\mathrm{BIO10}$ and BIO12 (Lecanora fuscobrunnea and Lecidea cancriformis) exhibited the lowest values of $\mathrm{NRI}$ and the highest values of PSR, as they had associations with the phylogenetically distinct Trebouxia OTUs A02, 101, S02 and S18 (Lecanora fuscobrunnea) or all seven Trebouxia OTUs of this study (Lecidea cancriformis), respectively. Additionally, Lecanora fuscobrunnea and Lecidea cancriformis were the two most widespread species that occurred in five of the six (L. fuscobrunnea) or all the six different areas (L. cancriformis). This result is in agreement with former studies that had shown that $L$. cancriformis is able to associate with all known photobiont species, and is one of the most widespread lichens in continental Antarctica (Castello 2003; Ruprecht et al. 2012a; Ruprecht et al. 2010; Wagner et al. 2020). Previous studies suggested that a higher photobiont diversity within a single lichen species is indicative of a lower selectivity by the mycobiont, and that this condition is related to enhanced colonization ability (Blaha et al. 2006; Guzow-Krzeminska 2006; Wirtz et al. 2003). According to a model developed by Yahr et al. (2006), selectivity may vary between habitats and may enable lichens to select a photobiont that is well adapted to conditions of the local environmental. These photobiont switches were suggested to increase the geographical range and ecological niche of lichen mycobionts, but may also lead to genetic isolation between mycobiont populations and thus drive their evolution (FernandezMendoza et al. 2011). More generally, flexibility concerning the partner choice has been considered to be an adaptive strategy to survive harsher environmental conditions (Engelen et al. 2016; Leavitt et al. 2013; Singh et al. 2017; Werth and Sork 2010).

Dal Grande et al. (2018) reported elevational preferences for some Trebouxia taxa at the OTU level at a mountain range in central Spain, covering an elevational gradient of $1400 \mathrm{~m}$. Additionally, in the present study, the mean elevation of photobiont OTUs were negatively correlated to differences in diversity indices: the dominant photobiont OTU $\operatorname{Tr}_{-}$A02, occurring in all the six different areas, exhibited the lowest mean value of elevation of sample sites and had the highest number of haplotypes and the highest value of haplotype diversity. On the other hand, the OTUs Tr_S15 and Tr_S18 had the highest mean elevations and the lowest values of $h$ and $H d$. Thus, higher mean elevation of photobiont OTUs were significantly related to a lower number of haplotypes $(h)$ and a lower haplotype diversity $(H d)$. 
bioRxiv preprint doi: https://doi.org/10.1101/2021.05.26.445136; this version posted May 27, 2021. The copyright holder for this preprint (which

was not certified by peer review) is the author/funder, who has granted bioRxiv a license to display the preprint in perpetuity. It is made available under aCC-BY-NC-ND 4.0 International license.

Symbiotic associations in lecideoid lichens along the Transantarctic Mountains, Antarctica

Wagner et al. 2021

\section{Conclusions}

Lichens and their myco-/photobiont associations clearly show environmental preferences and therefore are useful as bioindicators.

The Trebouxia OTU A02 occurred in all the six different areas and was dominant in milder areas, whereas in colder areas, a higher relative abundance of other Trebouxia OTUs was found. Accordingly, mycobiont species occurring in milder areas (like Carbonea vorticosa, Lecidella greenii and Rhizoplaca macleanii) are almost exclusively associated with $T r_{-} \mathrm{A} 02$, while the generalist mycobiont species Lecidea cancriformis und Lecanora fuscobrunnea, occurring in a broad range of climatically different environments, show associations with phylogenetically distinct photobiont OTUs. However, if they are the only lecideoid lichen species present in certain areas, then they are also meaningful bioindicators of extreme climatic conditions.

\section{Acknowledgements}

We want to thank D. Laina, G. Zimmermann, the IDA Lab (Salzburg, A) and T.G.A. Green (Waikato, NZ) for various help and valuable advice and suggestions.

\section{Funding}

Austrian Science Fund (FWF) P26638_B16, Diversity, ecology, and specificity of Antarctic lichens; lichen collections: FRST-funded IPY Research Programme "Understanding, valuing and protecting Antarctica's unique terrestrial ecosystems: Predicting biocomplexity in Dry Valley ecosystems" and NZTABS supported through a grant to ICTAR at Waikato University. Antarctica New Zealand provided logistic and Waikato University (NZ) financial support. CRYPTOCOVER (Spanish Ministry of Science CTM201564728-C2-1-R).

\section{Additional information}

Competing interests: The authors declare no competing interests.

Supplementary information: Supplementary Material 1: Tables, Supplementary Material 2: Figures

\section{References}

Adams BJ et al. (2006) Diversity and distribution of Victoria Land biota. Soil Biology \& Biochemistry 38:3003-3018

Alatalo JM, Jagerbrand AK, Molau U (2015) Testing reliability of short-term responses to predict longer-term responses of bryophytes and lichens to environmental change. Ecological Indicators 58:77-85

Allen JL, Lendemer JC (2016) Climate change impacts on endemic, high-elevation lichens in a biodiversity hotspot. Biodiversity and Conservation 25:555-568 
bioRxiv preprint doi: https://doi.org/10.1101/2021.05.26.445136; this version posted May 27, 2021. The copyright holder for this preprint (which

was not certified by peer review) is the author/funder, who has granted bioRxiv a license to display the preprint in perpetuity. It is made available under aCC-BY-NC-ND 4.0 International license.

Symbiotic associations in lecideoid lichens along the Transantarctic Mountains, Antarctica

Wagner et al. 2021

Aschenbrenner IA, Cernava T, Berg G, Grube M (2016) Understanding Microbial Multi-Species Symbioses. Frontiers in Microbiology 7

Baird HP, Janion-Scheepers C, Stevens MI, Leihy RI, Chown SL (2019) The ecological biogeography of indigenous and introduced Antarctic springtails. J Biogeogr 46:1959-1973

Bassler $C$ et al. (2016) Contrasting patterns of lichen functional diversity and species richness across an elevation gradient. Ecography 39:689-698

Blaha J, Baloch E, Grube M (2006) High photobiont diversity associated with the euryoecious lichen-forming ascomycete Lecanora rupicola (Lecanoraceae, Ascomycota). Biological Journal of the Linnean Society 88:283-293

Cary SC, McDonald IR, Barrett JE, Cowan DA (2010) On the rocks: the microbiology of Antarctic Dry Valley soils Nature Reviews. Microbiology 8:129-138

Castello M (2003) Lichens of Terra Nova Bay area, northern Victoria Land (Continental Antarctica). Studia Geobotanica:3-54

Colesie C, Green TGA, Turk R, Hogg ID, Sancho LG, Budel B (2014) Terrestrial biodiversity along the Ross Sea coastline, Antarctica: lack of a latitudinal gradient and potential limits of bioclimatic modeling. Polar Biology 37:1197-1208

Dal Grande F, Rolshausen G, Divakar PK, Crespo A, Otte J, Schleuning M, Schmitt I (2018) Environment and host identity structure communities of green algal symbionts in lichens. New Phytologist 217:277-289

Dal Grande F et al. (2017) Adaptive differentiation coincides with local bioclimatic conditions along an elevational cline in populations of a lichen-forming fungus. Bmc Evolutionary Biology 17

De los Rios A, Sancho LG, Wierzchos J, Ascaso C (2004) Endolithic growth of two Lecidea lichens in granite from continental Antarctica detected by molecular and microscopy techniques. New Phytologist 165:181-190

Dormann CF (2011) How to be a specialist? Quantifying specialisation in pollination networks Network. Biology 1:1-20

Dormann CF, Gruber B, Fruend J (2008) Introducing the bipartite Package: Analysing Ecological Networks. R news 8/2:8-11

Ellis CJ (2019) Climate Change, Bioclimatic Models and the Risk to Lichen Diversity. Diversity 11:54

Engelen A, Convey P, Popa O, Ott S (2016) Lichen photobiont diversity and selectivity at the southern limit of the maritime Antarctic region (Coal Nunatak, Alexander Island). Polar Biol 39:2403-2410

Fernandez-Mendoza F, Domaschke S, Garcia MA, Jordan P, Martin MP, Printzen C (2011) Population structure of mycobionts and photobionts of the widespread lichen Cetraria aculeata. Molecular Ecology 20:1208-1232

Gardes M, Bruns TD (1993) Its Primers with Enhanced Specificity for Basidiomycetes - Application to the Identification of Mycorrhizae and Rusts. Molecular Ecology 2:113-118

Green TGA (2009) Lichens in arctic, antarctic and alpine ecosystems. Rundgespräche der Kommission für Ökologie. In: Ökologische Rolle der Flechten. vol 36. Verlag Dr. Friedrich Pfeil, pp 45-65

Green TGA, Sancho LG, Pintado A, Schroeter B (2011a) Functional and spatial pressures on terrestrial vegetation in Antarctica forced by global warming. Polar Biology 34:1643-1656

Green TGA, Sancho LG, Turk R, Seppelt RD, Hogg ID (2011b) High diversity of lichens at 84 degrees S, Queen Maud Mountains, suggests preglacial survival of species in the Ross Sea region, Antarctica. Polar Biology 34:1211-1220

Grube M et al. (2015) Exploring functional contexts of symbiotic sustain within lichen-associated bacteria by comparative omics. Isme Journal 9:412-424 
bioRxiv preprint doi: https://doi.org/10.1101/2021.05.26.445136; this version posted May 27, 2021. The copyright holder for this preprint (which

was not certified by peer review) is the author/funder, who has granted bioRxiv a license to display the preprint in perpetuity. It is made available under aCC-BY-NC-ND 4.0 International license.

Symbiotic associations in lecideoid lichens along the Transantarctic Mountains, Antarctica

Wagner et al. 2021

Guindon S, Dufayard JF, Lefort V, Anisimova M, Hordijk W, Gascuel O (2010) New Algorithms and Methods to Estimate MaximumLikelihood Phylogenies: Assessing the Performance of PhyML 3.0. Systematic Biology 59:307-321

Guzow-Krzeminska B (2006) Photobiont flexibility in the lichen Protoparmeliopsis muralis as revealed by ITS rDNA analyses. The Lichenologist 38:469-476

Head JW, Marchant DR (2014) The climate history of early Mars: insights from the Antarctic McMurdo Dry Valleys hydrologic system. Antarctic Science 26:774-800

Hertel H (1998) Flechten im Hochgebirge Naturerlebnis Alpen (Jubiläumsschrift zum 50-jährigen Bestehen der naturkundlichen Abteilung der Sektion München im Deutschen Alpenverein EV):33-48

Hertel H (2007) Notes on and records of Southern Hemisphere lecideoid lichens. Bibliotheca Lichenologica 95:267-296

Hijmans RJ (2020) raster: Geographic Data Analysis and Modeling. R package version 31-5

Kalyaanamoorthy S, Minh BQ, Wong TKF, von Haeseler A, Jermiin LS (2017) ModelFinder: fast model selection for accurate phylogenetic estimates. Nature Methods 14:587-+

Kappen L, Valladares F (2007) Opportunistic growth and desiccation tolerance: the ecological success of poikilohydrous autotrophs. Functional plant ecology. Books in soils, plants, and the environment, 2nd edn. CRC Press, Boca Raton, FL

Karger DN et al. (2017) Climatologies at high resolution for the earth's land surface areas. Sci Data 4

Katoh K, Misawa K, Kuma K, Miyata T (2002) MAFFT: a novel method for rapid multiple sequence alignment based on fast Fourier transform. Nucleic Acids Research 30:3059-3066

Kroken S, Taylor JW (2000) Phylogenetic species, reproductive mode, and specificity of the green alga Trebouxia forming lichens with the fungal genus Letharia. Bryologist 103:645-660

Lagostina E et al. (2021) Effects of dispersal strategy and migration history on genetic diversity and population structure of Antarctic lichens. J. of Biogeography

Lawrey JD, Diederich P (2003) Lichenicolous fungi: Interactions, evolution, and biodiversity. Bryologist 106:80-120

Leavitt SD et al. (2015) Fungal specificity and selectivity for algae play a major role in determining lichen partnerships across diverse ecogeographic regions in the lichen-forming family Parmeliaceae (Ascomycota.) Molecular Ecology 24:3779-3797

Leavitt SD, Nelsen MP, Lumbsch HT, Johnson LA, St Clair LL (2013) Symbiont flexibility in subalpine rock shield lichen communities in the Southwestern USA. Bryologist 116:149-161

Lindgren H, Velmala S, Hognabba F, Goward T, Holien H, Myllys L (2014) High fungal selectivity for algal symbionts in the genus Bryoria. Lichenologist 46:681-695

Magalhaes C et al. (2012) At Limits of Life: Multidisciplinary Insights Reveal Environmental Constraints on Biotic Diversity in Continental Antarctica. Plos One 7(9): e44578

Marcon E, Hérault B (2015) entropart: An R Package to Measure and Partition Diversity. Journal of Statistical Software, Articles 67:26

Matheny PB, Liu YJJ, Ammirati JF, Hall BD (2002) Using RPB1 sequences to improve phylogenetic inference among mushrooms (Inocybe, Agaricales). American Journal of Botany 89:688-698

Matsuoka K, Skoglund A, Roth G (2018) Quantarctica [data set]. Norwegian Polar Institute 
bioRxiv preprint doi: https://doi.org/10.1101/2021.05.26.445136; this version posted May 27, 2021. The copyright holder for this preprint (which

was not certified by peer review) is the author/funder, who has granted bioRxiv a license to display the preprint in perpetuity. It is made available under aCC-BY-NC-ND 4.0 International license.

Symbiotic associations in lecideoid lichens along the Transantarctic Mountains, Antarctica

Wagner et al. 2021

Mayer W, Pfefferkorn-Dellali V, Turk R, Dullinger S, Mirtl M, Dirnbock T (2013) Significant decrease in epiphytic lichen diversity in a remote area in the European Alps, Austria. Basic and Applied Ecology 14:396-403

McKendry IG, Lewthwaite EW (1990) The vertical structure of summertime local winds in the Wright Valley, Antarctica BoundaryLayer. Meteorology 51:321-342

Minh BQ, Nguyen MAT, von Haeseler A (2013) Ultrafast Approximation for Phylogenetic Bootstrap. Molecular Biology and Evolution 30:1188-1195

Monaghan AJ, Bromwich DH, Powers JG, Manning KW (2005) The Climate of the McMurdo, Antarctica, Region as Represented by One Year of Forecasts from the Antarctic Mesoscale Prediction System. Journal of Climate 18:1174-1189

Muggia L et al. (2020) Formally described species woefully underrepresent phylogenetic diversity in the common lichen photobiont genus Trebouxia (Trebouxiophyceae, Chlorophyta): An impetus for developing an integrated taxonomy. Molecular Phylogenetics and Evolution 149:106821

Nei M (1987) Molecular Evolutionary Genetics. Columbia University Press, New York

Nei M, Li WH (1979) Mathematical model for studying genetic variation in terms of restriction endonucleases Proceedings of the National Academy of Sciences of the United States of America 76:5269-5273

Nguyen L-T, Schmidt HA, von Haeseler A, Minh BQ (2014) IQ-TREE: A Fast and Effective Stochastic Algorithm for Estimating Maximum-Likelihood Phylogenies. Molecular Biology and Evolution 32:268-274

Nix HA (1986) A biogeographic analysis of Australian elapid snakes. In: Atlas of elapid snakes of Australia. Australian Flora and Fauna Series 7. Australian Government Publishing Service, Canberra,

Ochyra R, Lewis Smith RI, Bednarek-Ochyra H (2008) The illustrated moss flora of Antarctica. Cambridge University Press

Oksanen J et al. (2019) vegan: Community Ecology Package. R package version 2.5-6.

Paradis E (2010) pegas: an R package for population genetics with an integrated-modular approach. Bioinformatics 26:419-420

Peat HJ, Clarke A, Convey P (2007) Diversity and biogeography of the Antarctic flora. Journal of Biogeography 34:132-146

Peksa O, Skaloud P (2011) Do photobionts influence the ecology of lichens? A case study of environmental preferences in symbiotic green alga Asterochloris (Trebouxiophyceae). Molecular Ecology 20:3936-3948

Perez-Ortega S, Ortiz-Alvarez R, Allan Green TG, de Los Rios A (2012) Lichen myco- and photobiont diversity and their relationships at the edge of life (McMurdo Dry Valleys, Antarctica). FEMS Microbiol Ecol 82:429-448

Puillandre N, Lambert A, Brouillet S, Achaz G (2012) ABGD, Automatic Barcode Gap Discovery for primary species delimitation. Molecular Ecology 21:1864-1877

R Core Team (2020) R: A language and environment for statistical computing R Foundation for Statistical Computing

Rolshausen G, Dal Grande F, Sadowska-Deś AD, Otte J, Schmitt I (2018) Quantifying the climatic niche of symbiont partners in a lichen symbiosis indicates mutualist-mediated niche expansions. Ecography 41:1380-1392

Rolshausen G, Hallman U, Grande FD, Otte J, Knudsen K, Schmitt I (2020) Expanding the mutualistic niche: parallel symbiont turnover along climatic gradients Proceedings of the Royal Society B 287:20192311

RStudio Team (2016) RStudio: Integrated Development for R. RStudio, Inc

Ruprecht U, Brunauer G, Printzen C (2012a) Genetic diversity of photobionts in Antarctic lecideoid lichens from an ecological viewpoint. Lichenologist 44:661-678 
bioRxiv preprint doi: https://doi.org/10.1101/2021.05.26.445136; this version posted May 27, 2021. The copyright holder for this preprint (which

was not certified by peer review) is the author/funder, who has granted bioRxiv a license to display the preprint in perpetuity. It is made available under aCC-BY-NC-ND 4.0 International license.

Symbiotic associations in lecideoid lichens along the Transantarctic Mountains, Antarctica

Wagner et al. 2021

Ruprecht U, Brunauer G, Turk R (2014) High photobiont diversity in the common European soil crust lichen Psora decipiens. Biodiversity and Conservation 23:1771-1785

Ruprecht U, Fernandez-Mendoza F, Turk R, Fryday AM (2020) High levels of endemism and local differentiation in the fungal and algal symbionts of saxicolous lecideoid lichens along a latitudinal gradient in southern South America. Lichenologist (Lond) 52:287-303

Ruprecht U, Lumbsch HT, Brunauer G, Green TGA, Turk R (2012b) Insights into the Diversity of Lecanoraceae (Lecanorales, Ascomycota) in continental Antarctica (Ross Sea region). Nova Hedwigia 94:287-306

Ruprecht U, Lumbsch HT, Brunauer G, Green TGA, Türk R (2010) Diversity of Lecidea (Lecideaceae, Ascomycota) species revealed by molecular data and morphological characters. Antarctic Science 22:727-741

Sancho LG, Pintado A, Green T (2019) Antarctic studies show lichens to be excellent biomonitors of climate change. Diversity 11:42

Sancho LG et al. (2017) Recent Warming and Cooling in the Antarctic Peninsula Region has Rapid and Large Effects on Lichen Vegetation. Scientific Reports 7

Schroeter B, Green TGA, Pannewitz S, Schlensog M, Sancho LG (2011) Summer variability, winter dormancy: lichen activity over 3 years at Botany Bay, 77 degrees S latitude, continental Antarctica. Polar Biology 34:13-22

Singh G, Dal Grande F, Divakar PK, Otte J, Crespo A, Schmitt I (2017) Fungal-algal association patterns in lichen symbiosis linked to macroclimate. New Phytologist 214:317-329

Spribille T et al. (2016) Basidiomycete yeasts in the cortex of ascomycete macrolichens. Science 353:488-492

Sundqvist MK, Sanders NJ, Wardle DA (2013) Community and Ecosystem Responses to Elevational Gradients: Processes, Mechanisms, and Insights for Global Change. Annual Review of Ecology, Evolution, and Systematics, Vol 44 44:261-280

Vančurová L, Muggia L, Peksa O, Řídká T, Škaloud P (2018) The complexity of symbiotic interactions influences the ecological amplitude of the host: A case study in Stereocaulon (lichenized Ascomycota). Molecular Ecology 27:3016-3033

Wagner M, Bathke AC, Cary SC, Green TGA, Junker RR, Trutschnig W, Ruprecht U (2020) Myco- and photobiont associations in crustose lichens in the McMurdo Dry Valleys (Antarctica) reveal high differentiation along an elevational gradient. Polar Biol 43:1967-1983

Werth S, Sork VL (2010) Identity and genetic structure of the photobiont of the epiphytic lichen Ramalina menziesii on three oak species in Southern California American Journal of Botany 97:821-830

White TJ, Bruns TD, Lee SB, Taylor JW (1990) Amplification and direct sequencing of fungal ribosomal RNA Genes for phylogenies. In: Innis MA, Gelfand DH, Sninsky JJ, White TJ (eds) PCR Protocols: A Guide to Methods and Applications. Academic Press, San Diego, pp 315-322

Whittaker RH (1960) Vegetation of the Siskiyou Mountains, Oregon and California. Ecological Monographs 30:279-338

Wickham H (2009) ggplot2: Elegant Graphics for Data Analysis. Springer-Verlag, New York

Wirtz N, Lumbsch HT, Green TGA, Turk R, Pintado A, Sancho L, Schroeter B (2003) Lichen fungi have low cyanobiont selectivity in maritime Antarctica. New Phytologist 160:177-183

Yahr R, Vilgalys R, DePriest PT (2006) Geographic variation in algal partners of Cladonia subtenuis (Cladoniaceae) highlights the dynamic nature of a lichen symbiosis. New phytologist 171:847-860

Yung CCM et al. (2014) Characterization of Chasmoendolithic Community in Miers Valley, McMurdo Dry Valleys, Antarctica. Microbial Ecology 68:351-359 
How do symbiotic associations in lecideoid lichens respond to different environmental conditions along the Transantarctic Mountains, Ross Sea region, Antarctica? | Wagner M, Brunauer G, Bathke AC, Cary SC, Fuchs R, Sancho LG, Türk R, Ruprecht U | University of Salzburg

\section{Supplementary Material 1: Tables}

\section{Contents}

Supplementary Table S1

Supplementary Table S2

Supplementary Table S3

Supplementary Table S4

Supplementary Table S5

Supplementary Table $\mathrm{S} 6$

Supplementary Table S7

References

2

3

7

$-9$

13


How do symbiotic associations in lecideoid lichens respond to different environmental conditions along the Transantarctic Mountains, Ross Sea region, Antarctica? | Wagner M, Brunauer G, Bathke AC, Cary SC, Fuchs R, Sancho LG, Türk R, Ruprecht U | University of Salzburg

Supplementary Table S1. Geographical description of sampling sites.

\begin{tabular}{|c|c|c|c|c|}
\hline & Sampling area & $\begin{array}{l}\text { Range of } \\
\text { coordinates of } \\
\text { sampling sites }\end{array}$ & Collected by & Geographical description \\
\hline $\begin{array}{c}\text { Area } \\
1\end{array}$ & $\begin{array}{l}\text { Scott Glacier/ } \\
\text { Durham Point }\end{array}$ & $\begin{array}{l}\text { S } 85.54^{\circ} \\
\text { W } 151.15^{\circ}\end{array}$ & Leo Sancho (2011) & $\begin{array}{l}\text { Durham Point emerges as a big cliff closed to the confluence of Scott Glacier with the Ross Ice Shelf and it is surrounded by frozen } \\
\text { lakes. The substrate is predominantly made up of crystalline plutonic (granite) or metamorphic rocks. }\end{array}$ \\
\hline $\begin{array}{c}\text { Area } \\
2\end{array}$ & $\begin{array}{l}\text { Massam Glacier/ } \\
\text { Garden Spur }\end{array}$ & $\begin{array}{c}\text { S } 84.54^{\circ}-84.56^{\circ} \\
\text { W } 174.91^{\circ}-175.01^{\circ}\end{array}$ & Leo Sancho (2011) & $\begin{array}{l}\text { Garden Spur is a narrow rocky ridge at the lowest end of Shackleton Glacier. The substrate is predominantly made up of crystalline } \\
\text { plutonic (granite) or metamorphic rocks. }\end{array}$ \\
\hline $\begin{array}{c}\text { Area } \\
3\end{array}$ & $\begin{array}{l}\text { Mt. Kyffin, The } \\
\text { Gateway, Mt. } \\
\text { Harcourt }\end{array}$ & $\begin{array}{c}S 83.49^{\circ}-83.83^{\circ} \\
\text { E } 170.79^{\circ}-172.76^{\circ}\end{array}$ & $\begin{array}{l}\text { Leo Sancho (2011) } \\
\text { Roman Türk (2003) }\end{array}$ & $\begin{array}{l}\text { The investigated area of Mt. Kyffin, Gateway, Mt. Harcourt and surroundings is located at the southern edge of Beardsmore Glacier. } \\
\text { The mountains are formed by Goldie Formation greywacke (Gunn and Walcott 1962) and schist as well as crystalline plutonic (granite) } \\
\text { or metamorphic rocks. }\end{array}$ \\
\hline $\begin{array}{c}\text { Area } \\
4 a\end{array}$ & $\begin{array}{l}\text { Darwin Area: } \\
\text { Diamond Hills, } \\
\text { Brown Hills }\end{array}$ & $\begin{array}{c}\text { S } 79.84^{\circ}-79.88^{\circ} \\
\text { E } 159.22^{\circ}-159.39^{\circ}\end{array}$ & $\begin{array}{l}\text { RomanTürk (2004, } \\
\text { 2009) }\end{array}$ & $\begin{array}{l}\text { Diamond Hill is located at the eastern edge of the Transantarctic Mountains, close to the Ross Ice Shelf and north from the Darwin } \\
\text { Glacier. Climate conditions are characterized by higher air humidity and precipitation that support a higher diversity and abundance of } \\
\text { lichens. } \\
\text { The Brown Hills are located in the north of Darwin Glacier. The Carlyon Granodiorite makes up most of the Brown Hills and includes a } \\
\text { variably foliated, biotite-hornblende granodiorite and granite (Simpson and Cooper 2002). This site appears to be a particularly dry part } \\
\text { of the continental Transantarctic Range. }\end{array}$ \\
\hline $\begin{array}{c}\text { Area } \\
4 \mathrm{~b}\end{array}$ & $\begin{array}{l}\text { Darwin Area: } \\
\text { Bartrum Basin, } \\
\text { Smith Valley, Lake } \\
\quad \text { Wellman }\end{array}$ & $\begin{array}{c}S 79.75^{\circ}-79.95^{\circ} \\
\text { E } 156.70^{\circ}-158.67^{\circ}\end{array}$ & $\begin{array}{l}\text { RomanTürk (2004, } \\
2007,2009)\end{array}$ & $\begin{array}{l}\text { Bartrum Basin is a very dry area, located in the north-west of the Brown Hills very dry area. The dominant rock types are dolerite and } \\
\text { granite. } \\
\text { The surroundings of the Smith Valley and Lake Wellman are characterized by a very dry climate, caused by a high evaporation rate } \\
\text { due to low average air humidity and/or continuous winds originating from the cold glacier regions. The bedrock surrounding this area is } \\
\text { sandstone from the Beacon Group and dolerite from the Ferrar dolerite sills. }\end{array}$ \\
\hline $\begin{array}{c}\text { Area } \\
5\end{array}$ & $\begin{array}{l}\text { McMurdo Dry } \\
\text { Valleys }\end{array}$ & $\begin{array}{c}\text { S } 78.02^{\circ}-78.17^{\circ} \\
\text { E } 163.62^{\circ}-164.10^{\circ}\end{array}$ & $\begin{array}{l}\text { Roman Türk (2010) } \\
\text { Ulrike Ruprecht } \\
(2009,2011)\end{array}$ & $\begin{array}{l}\text { The landscape of the McMurdo Dry Valleys is a mosaic of glacially formed valleys with intervening high ground, ice-covered lackes, } \\
\text { ephemeral streams, arid rocky soils, ice-cemented soils, and surrounding glaciers along the steep scree and boulder slopes (Doran et } \\
\text { al. 2002; Stichbury et al. 2011; Yung et al. 2014). There are four main valleys (Miers Valley, Garwood Valley, Hidden Valley, and Marshall } \\
\text { Valley) and some other extensive ice-free areas (Shangri-La). The valleys have the typical glaciated form with a U-cross-section with } \\
\text { steep sides, often with scree slopes, and the valley floors are covered with glacial drift. }\end{array}$ \\
\hline
\end{tabular}


How do symbiotic associations in lecideoid lichens respond to different environmental conditions along the Transantarctic Mountains, Ross Sea region, Antarctica? | Wagner M, Brunauer G, Bathke AC, Cary SC, Fuchs R, Sancho LG, Türk R, Ruprecht U | University of Salzburg

Supplementary Table S2. Samples used in this study, with information on collecting localities and Genbank accession numbers of different markers.

\begin{tabular}{|c|c|c|c|c|c|c|c|c|c|c|c|}
\hline \multirow[b]{3}{*}{ Voucher ID } & \multirow[b]{3}{*}{ Area } & \multirow[b]{3}{*}{ Latitude } & \multirow[b]{3}{*}{ Longitude } & \multicolumn{4}{|c|}{ Mycobiont } & \multicolumn{4}{|c|}{ Associated green micro algae (Trebouxia) } \\
\hline & & & & \multirow[b]{2}{*}{ Species name } & \multicolumn{3}{|c|}{ Accession numbers } & \multirow[b]{2}{*}{ OTU ID } & \multicolumn{3}{|c|}{ Accession numbers } \\
\hline & & & & & nrlTS & mtSSU & RPB1 & & nrITS2 & psbJ-L & $\operatorname{cox} 2$ \\
\hline MAF_DP1_01 & 1 & -85.539 & -151.150 & Lecidea cancriformis Dodge \& Baker & MK208709 & MK205016 & MK226962 & Tr_S02 & MK226844 & MK226760 & MK227045 \\
\hline MAF_DP1_02 & 1 & -85.539 & -151.150 & Lecanora fuscobrunnea Dodge \& Baker & MK208710 & MK205017 & MK226963 & Tr_S02 & MK226845 & MK226761 & MK227046 \\
\hline MAF_DP1_04 & 1 & -85.539 & -151.150 & Lecidea cancriformis Dodge \& Baker & MK208711 & MK205018 & MK226964 & Tr_S02 & MK226846 & MK226800 & MK227047 \\
\hline MAF_DP1_06 & 1 & -85.539 & -151.150 & Lecidea cancriformis Dodge \& Baker & MK208712 & MK205019 & MK226965 & Tr_S02 & - & MK226812 & MK227048 \\
\hline MAF_DP1_07 & 1 & -85.539 & -151.150 & Lecanora sp. 3 & MK208713 & - & - & Tr_A02 & MK226847 & MK226736 & MK227049 \\
\hline MAF_DP1_08 & 1 & -85.539 & -151.150 & Lecanora fuscobrunnea Dodge \& Baker & MK208714 & MK205021 & MK226966 & Tr_A02 & MK226848 & MK226737 & MK227050 \\
\hline MAF_DP1_09 & 1 & -85.539 & -151.150 & Lecidea cancriformis Dodge \& Baker & MK208715 & MK205022 & - & Tr_S02 & MK226849 & MK226801 & MK227051 \\
\hline MAF_DP1_10 & 1 & -85.539 & -151.150 & Lecidea cancriformis Dodge \& Baker & MK208716 & MK205023 & MK226967 & Tr_S02 & MK226850 & MK226802 & MK227052 \\
\hline MAF_DP1_11 & 1 & -85.539 & -151.150 & Lecidea cancriformis Dodge \& Baker & MK208717 & MK205024 & MK226968 & Tr_S02 & MK226851 & MK226762 & MK227053 \\
\hline MAF_DP1_15 & 1 & -85.539 & -151.150 & Lecidella greenii Ruprecht \& Türk & MK208718 & - & MK226969 & Tr_A02 & MK226852 & MK226738 & MK227054 \\
\hline MAF_DP1_19 & 1 & -85.539 & -151.150 & Lecidea cancriformis Dodge \& Baker & MK208719 & MK205025 & MK226970 & - & - & - & - \\
\hline MAF_DP1_20 & 1 & -85.539 & -151.150 & Lecanora fuscobrunnea Dodge \& Baker & MK208720 & MK205026 & MK226971 & Tr_A02 & MK226853 & MK226739 & MK227055 \\
\hline MAF_DP1_22 & 1 & -85.539 & -151.150 & Lecidella siplei Dodge \& Baker & MK208721 & - & - & $\operatorname{Tr}$ A02 & MK226854 & MK226740 & MK227056 \\
\hline MAF_DP1_24 & 1 & -85.539 & -151.150 & Lecidea cancriformis Dodge \& Baker & MK208722 & MK205027 & MK226972 & $\operatorname{Tr} 101$ & MK226855 & - & - \\
\hline MAF_DP1_25 & 1 & -85.539 & -151.150 & Lecidea cancriformis Dodge \& Baker & MK208723 & MK205028 & MK226973 & Tr_A02 & MK226856 & MK226741 & MK227057 \\
\hline MAF_DP1_28 & 1 & -85.539 & -151.150 & Lecanora fuscobrunnea Dodge \& Baker & MK208724 & MK205029 & MK226974 & Tr_S02 & MK226857 & MK226771 & MK227058 \\
\hline MAF_DP1_30 & 1 & -85.539 & -151.150 & Lecidea cancriformis Dodge \& Baker & MK208725 & MK205030 & - & Tr_S02 & MK226858 & MK226764 & MK227059 \\
\hline MAF_DP1_32 & 1 & -85.539 & -151.150 & Lecanora fuscobrunnea Dodge \& Baker & MK208726 & MK205031 & MK226975 & Tr_A02 & MK226859 & MK226742 & MK227060 \\
\hline MAF_DP1_33 & 1 & -85.539 & -151.150 & Lecidea cancriformis Dodge \& Baker & MK208727 & MK205032 & MK226976 & Tr_S02 & MK226860 & MK226765 & MK227061 \\
\hline MAF_DP1_34 & 1 & -85.539 & -151.150 & Lecidea cancriformis Dodge \& Baker & MK208728 & MK205033 & MK226977 & Tr_S02 & MK226861 & MK226813 & MK227062 \\
\hline MAF_DP1_35 & 1 & -85.539 & -151.150 & Lecidella siplei Dodge \& Baker & MK208729 & - & - & Tr_A02 & MK226862 & MK226743 & MK227063 \\
\hline MAF_DP1_36 & 1 & -85.539 & -151.150 & Lecidea cancriformis Dodge \& Baker & MK208730 & MK205034 & MK226978 & Tr_S02 & MK226863 & MK226815 & MK227064 \\
\hline MAF_DP1_39 & 1 & -85.539 & -151.150 & Lecidea cancriformis Dodge \& Baker & MK208731 & MK205035 & MK226979 & Tr_S02 & - & MK226816 & MK227065 \\
\hline MAF_DP1_50 & 1 & -85.539 & -151.150 & Lecanora fuscobrunnea Dodge \& Baker & MK208732 & MK205036 & MK226981 & Tr_A02 & - & MK226745 & MK227067 \\
\hline MAF_DP1_51 & 1 & -85.539 & -151.150 & Lecidella greenii Ruprecht \& Türk & MK208733 & MK205037 & MK226982 & Tr_A02 & MK226865 & MK226746 & MK227068 \\
\hline MAF_DP1_52 & 1 & -85.539 & -151.150 & Carbonea sp. URm1 & MK208734 & MK205038 & - & Tr_A02 & MK226866 & MK226747 & MK227069 \\
\hline MAF_DP1_54 & 1 & -85.539 & -151.150 & Carbonea sp. 2 & MK208735 & - & MK226984 & Tr_S02 & MK226868 & MK226772 & MK227071 \\
\hline MAF_DP1_57 & 1 & -85.539 & -151.150 & Lecidella siplei Dodge \& Baker & MK208736 & - & - & Tr_A02 & MK226869 & - & MK227072 \\
\hline MAF_GR1_29 & 3 & -83.487 & 170.790 & Lecidea cancriformis Dodge \& Baker & MK208737 & MK205039 & MK226985 & - & - & - & - \\
\hline MAF_GS1_12 & 2 & -84.535 & -174.954 & Lecidea andersonii Filson & MK208738 & MK205040 & - & Tr_S02 & MK226871 & MK226763 & MK227075 \\
\hline MAF_GS1_13 & 2 & -84.535 & -174.954 & Lecidella siplei Dodge \& Baker & MK208739 & - & - & Tr_A02 & MK226872 & - & MK227076 \\
\hline
\end{tabular}


How do symbiotic associations in lecideoid lichens respond to different environmental conditions along the Transantarctic Mountains, Ross Sea region, Antarctica? | Wagner M, Brunauer G, Bathke AC, Cary SC, Fuchs R, Sancho LG, Türk R, Ruprecht U | University of Salzburg

\begin{tabular}{|c|c|c|c|c|c|c|c|c|c|c|c|}
\hline \multirow[b]{3}{*}{ Voucher ID } & \multirow[b]{3}{*}{ Area } & \multirow[b]{3}{*}{ Latitude } & \multirow[b]{3}{*}{ Longitude } & \multicolumn{4}{|c|}{ Mycobiont } & \multicolumn{4}{|c|}{ Associated green micro algae (Trebouxia) } \\
\hline & & & & & \multicolumn{3}{|c|}{ Accession numbers } & & \multicolumn{3}{|c|}{ Accession numbers } \\
\hline & & & & Species name & nrlTS & mtSSU & RPB1 & OTU ID & nrlTS2 & psbJ-L & $\operatorname{cox} 2$ \\
\hline MAF_GS1_44 & 2 & -84.535 & $-174,954$ & Lecidea andersonii Filson & MK208740 & MK205041 & - & Tr_A02 & MK226873 & - & MK227077 \\
\hline MAF_GS1_45 & 2 & -84.535 & -174.954 & Lecanora physciella (Darb.) Hertel & MK208741 & - & MK226986 & Tr_S02 & MK226874 & MK226766 & MK227078 \\
\hline MAF_GS1_58 & 2 & -84.535 & -174.954 & Lecidella siplei Dodge \& Baker & MK208742 & - & - & Tr_A02 & MK226875 & - & MK227079 \\
\hline MAF_GS1_60 & 2 & -84.535 & -174.954 & Lecidella siplei Dodge \& Baker & MK208743 & - & - & Tr_A02 & MK226876 & - & - \\
\hline MAF_GS1_61 & 2 & -84.535 & -174.954 & Lecidea andersonii Filson & MK208744 & MK205042 & MK226987 & Tr_A02 & MK226877 & MK226749 & MK227080 \\
\hline MAF_GS1_62 & 2 & -84.535 & -174.954 & Lecidella siplei Dodge \& Baker & MK208745 & - & - & Tr_A02 & MK226878 & MK226750 & MK227081 \\
\hline MAF_GS1_64 & 2 & -84.535 & -174.954 & Lecidella sp. nov2 & MK208746 & MK205043 & MK226988 & Tr_S02 & MK226879 & MK226775 & MK227082 \\
\hline MAF_HS7_59 & 3 & -83.806 & 172.262 & Lecidella sp. nov2 & MK208747 & MK205044 & MK226989 & Tr_S02 & MK226880 & MK226810 & MK227083 \\
\hline MAF_MG1_16 & 2 & -84.559 & -175.009 & Lecidea andersonii Filson & MK208748 & MK205045 & MK226990 & Tr_A02 & MK226881 & MK226751 & MK227084 \\
\hline MAF_MG1_17 & 2 & -84.559 & -175.009 & Lecidea andersonii Filson & MK208749 & MK205046 & - & $\operatorname{Tr} \mathrm{A} 02$ & MK226882 & MK226752 & MK227085 \\
\hline MAF_MG1_23 & 2 & -84.559 & -175.009 & Lecidea andersonii Filson & MK208750 & MK205047 & MK226991 & Tr_A02 & - & - & MK227086 \\
\hline MAF_MG1_47 & 2 & -84.559 & -175.009 & Lecidea cancriformis Dodge \& Baker & MK208751 & - & - & $\operatorname{Tr} \mid 17$ & MK226883 & - & - \\
\hline MAF_MK1_03 & 3 & -83.775 & 171.828 & Lecanora fuscobrunnea Dodge \& Baker & MK208752 & MK205048 & MK226992 & Tr_A02 & MK226884 & MK226753 & MK227087 \\
\hline MAF_MK1_18 & 3 & -83.775 & 171.828 & Lecidella sp. nov2 & MK208753 & - & - & Tr_S02 & MK226886 & MK226767 & MK227089 \\
\hline MAF_MK1_21 & 3 & -83.775 & 171.828 & Lecidella sp. nov2 & MK208754 & MK205049 & - & Tr_S02 & MK226887 & MK226788 & MK227090 \\
\hline MAF_MK1_26 & 3 & -83.775 & 171.828 & Lecidea cancriformis Dodge \& Baker & MK208755 & MK205050 & MK226993 & Tr_S02 & MK226888 & MK226776 & MK227091 \\
\hline MAF_MK1_27 & 3 & -83.775 & 171.828 & Lecidella sp. nov2 & MK208756 & MK205051 & MK226994 & Tr_S02 & MK226889 & MK226777 & MK227092 \\
\hline MAF_MK1_31 & 3 & -83.775 & 171.828 & Lecidea cancriformis Dodge \& Baker & MK208757 & MK205052 & MK226995 & Tr_l01 & MK226890 & - & - \\
\hline MAF_MK1_37 & 3 & -83.775 & 171.828 & Lecidea cancriformis Dodge \& Baker & MK208758 & MK205053 & MK226996 & Tr_101 & MK226891 & - & - \\
\hline MAF_MK1_38 & 3 & -83.775 & 171.828 & Lecidea cancriformis Dodge \& Baker & MK208759 & MK205054 & - & Tr_S02 & MK226892 & MK226778 & MK227093 \\
\hline MAF_MK1_40 & 3 & -83.775 & 171.828 & Lecanora fuscobrunnea Dodge \& Baker & MK208760 & MK205055 & MK226997 & Tr_A02 & MK226893 & MK226754 & MK227094 \\
\hline MAF_MK1_43 & 3 & -83.775 & 171.828 & Lecidella sp. nov2 & MK208761 & MK205056 & - & Tr_S02 & MK226894 & MK226779 & MK227095 \\
\hline MAF_MK1_48 & 3 & -83.775 & 171.828 & Lecidea cancriformis Dodge \& Baker & MK208762 & MK205057 & MK226998 & Tr_S02 & MK226895 & MK226780 & MK227096 \\
\hline MAF_MK1_49 & 3 & -83.775 & 171.828 & Lecidella sp. nov2 & MK208763 & MK205058 & MK226999 & Tr_S02 & MK226896 & MK226799 & MK227097 \\
\hline MAF_MK1_55 & 3 & -83.775 & 171.828 & Lecidea cancriformis Dodge \& Baker & MK208764 & MK205059 & MK227000 & - & - & - & - \\
\hline MAF_MK1_56 & 3 & -83.775 & 171.828 & Lecanora fuscobrunnea Dodge \& Baker & MK208765 & MK205060 & MK227001 & Tr_S02 & MK226897 & MK226781 & MK227098 \\
\hline MAF_MK1_63 & 3 & -83.775 & 171.828 & Lecanora physciella (Darb.) Hertel & MK208766 & MK205061 & MK227002 & Tr_S02 & MK226898 & MK226789 & MK227099 \\
\hline MAF_Sancho & 3 & -83.761 & 172.755 & Lecidea cancriformis Dodge \& Baker & GU074439 & GU074489 & MK227003 & Tr_A04a & JN204838 & - & - \\
\hline MAF_Sancho & 3 & -83.761 & 172.755 & Carbonea sp. 2 & MK208767 & - & - & Tr_A04a & JN204839 & - & - \\
\hline Т33335 & 3 & -83.803 & 172.207 & Lecidella sp. nov2 & MK208768 & MK205062 & - & $\operatorname{Tr}$ S18 & MK226899 & - & - \\
\hline T33338 & 3 & -83.803 & 172.207 & Lecidella sp. nov2 & MK208769 & MK205063 & - & Tr_S02 & MK226900 & - & - \\
\hline T33346 & 3 & -83.803 & 172.207 & Lecanora physciella (Darb.) Hertel & JN873878 & - & - & - & - & - & - \\
\hline Т33348 & 3 & -83.803 & 172.207 & Lecidea cancriformis Dodge \& Baker & - & MK205064 & - & - & - & - & - \\
\hline
\end{tabular}


How do symbiotic associations in lecideoid lichens respond to different environmental conditions along the Transantarctic Mountains, Ross Sea region, Antarctica? | Wagner M, Brunauer G, Bathke AC, Cary SC, Fuchs R, Sancho LG, Türk R, Ruprecht U | University of Salzburg

\begin{tabular}{|c|c|c|c|c|c|c|c|c|c|c|c|}
\hline \multirow[b]{3}{*}{ Voucher ID } & \multirow[b]{3}{*}{ Area } & \multirow[b]{3}{*}{ Latitude } & \multirow[b]{3}{*}{ Longitude } & \multicolumn{4}{|c|}{ Mycobiont } & \multicolumn{4}{|c|}{ Associated green micro algae (Trebouxia) } \\
\hline & & & & & \multicolumn{3}{|c|}{ Accession numbers } & & \multicolumn{3}{|c|}{ Accession numbers } \\
\hline & & & & Species name & nrlTS & mtSSU & RPB1 & OTU ID & nrlTS2 & psbJ-L & $\operatorname{cox} 2$ \\
\hline T33446 & 3 & -83.828 & 172.749 & Lecidea cancriformis Dodge \& Baker & - & MK205065 & - & Tr_S18 & MK226901 & - & - \\
\hline T33449 & 3 & -83.761 & 172.755 & Lecidella siplei Dodge \& Baker & JN873897 & - & - & Tr_A02 & JN204729 & - & - \\
\hline Т33456 & 3 & -83.761 & 172.755 & Lecidea andersonii Filson & - & MK205066 & MK227004 & Tr_A02 & - & - & MK227100 \\
\hline T33457 & 3 & -83.761 & 172.755 & Lecidella siplei Dodge \& Baker & JN873898 & - & - & Tr_A02 & JN204731 & - & - \\
\hline T35540 & $4 a$ & -79.842 & 159.363 & Lecidella siplei Dodge \& Baker & MK208770 & - & - & - & - & - & - \\
\hline T35544 & $4 a$ & -79.838 & 159.341 & Lecanora fuscobrunnea Dodge \& Baker & JN873873 & - & - & - & - & - & - \\
\hline T35559 & $4 a$ & -79.838 & 159.221 & Lecidea cancriformis Dodge \& Baker & MK208771 & MK205067 & MK227005 & Tr_S18 & - & MK285375 & - \\
\hline T35604 & $4 a$ & -79.836 & 159.317 & Lecidea cancriformis Dodge \& Baker & EU257671 & GU074480 & MK227006 & Tr_S18 & JN204749 & - & - \\
\hline Т35620 & $4 a$ & -79.835 & 159.385 & Lecidea cancriformis Dodge \& Baker & EU257672 & - & - & $\operatorname{Tr}_{-} 101$ & JN204750 & - & - \\
\hline T35622 & $4 a$ & -79.835 & 159.392 & Lecidea cancriformis Dodge \& Baker & MK208772 & MK205068 & MK227007 & - & - & - & - \\
\hline T35647 & $4 a$ & -79.851 & 159.341 & Carbonea sp. 2 & JN873866 & - & - & Tr_S02 & JN204751 & - & - \\
\hline T35650 & $4 a$ & -79.851 & 159.341 & Carbonea sp. 2 & JN873867 & - & MK227008 & $\operatorname{Tr} \mathrm{S} 18$ & JN204752 & - & - \\
\hline T35662 & $4 a$ & -79.840 & 159.332 & Lecidea cancriformis Dodge \& Baker & EU257673 & - & - & Tr_101 & JN204753 & - & - \\
\hline T35664 & $4 a$ & -79.851 & 159.341 & Lecanora fuscobrunnea Dodge \& Baker & JN873874 & - & - & - & - & - & - \\
\hline T35686 & $4 a$ & -79.842 & 159.363 & Carbonea sp. 2 & JN873868 & - & - & - & - & - & - \\
\hline T42988 & $4 b$ & -79.889 & 156.764 & Lecidea cancriformis Dodge \& Baker & GU074435 & GU074481 & MK227009 & Tr_S18 & MK226902 & MK226818 & MK227101 \\
\hline T42990 & $4 b$ & -79.926 & 156.890 & Lecidea cancriformis Dodge \& Baker & GU170841 & - & MK227010 & Tr_S18 & JN204770 & MK226819 & MK227102 \\
\hline T42991 & $4 b$ & -79.917 & 156.759 & Lecidea cancriformis Dodge \& Baker & GU170842 & MK205069 & MK227011 & Tr_S18 & MK226903 & - & - \\
\hline T42992 & $4 b$ & -79.917 & 156.751 & Lecidea cancriformis Dodge \& Baker & GU074436 & GU074482 & MK227012 & Tr_S18 & JN204771 & MK226820 & MK227103 \\
\hline T42994 & $4 b$ & -79.879 & 157.539 & Lecanora fuscobrunnea Dodge \& Baker & GU170839 & MK205070 & MK227013 & Tr_S18 & MK226904 & - & - \\
\hline T44625 & $4 a$ & -79.868 & 159.360 & Lecanora fuscobrunnea Dodge \& Baker & MK208773 & MK205071 & MK227014 & Tr_A02 & MK226905 & MK226755 & MK227104 \\
\hline T44626 & $4 a$ & -79.882 & 159.361 & Carbonea sp. URm1 & JN873865 & - & MK227015 & $\operatorname{Tr}_{-} 101$ & JN204797 & - & - \\
\hline T44628 & $4 a$ & -79.865 & 159.352 & Lecanora fuscobrunnea Dodge \& Baker & JN873875 & MK205072 & MK227016 & Tr_S02 & - & MK226804 & MK227105 \\
\hline T44632 & $4 a$ & -79.868 & 159.352 & Lecanora fuscobrunnea Dodge \& Baker & MK208774 & MK205073 & MK227017 & $T r \_101$ & JN204800 & - & - \\
\hline T44633 & $4 a$ & -79.868 & 159.358 & Lecidea cancriformis Dodge \& Baker & MK208775 & MK205074 & - & Tr_S02 & - & MK226817 & MK227106 \\
\hline T44634 & $4 a$ & -79.869 & 159.341 & Lecidea cancriformis Dodge \& Baker & GU074434 & GU074486 & MK227018 & Tr_S18 & JN204801 & KF907601 & - \\
\hline T44636 & $4 a$ & -79.869 & 159.358 & Lecidella greenii Ruprecht \& Türk & MK208776 & - & - & Tr_A02 & MK226906 & - & - \\
\hline T44638 & $4 a$ & -79.869 & 159.358 & Lecidea cancriformis Dodge \& Baker & - & MK205075 & - & $\operatorname{Tr} \mathrm{S} 18$ & MK226907 & MK226827 & MK227107 \\
\hline T44640 & $4 a$ & -79.869 & 159.358 & Lecidea cancriformis Dodge \& Baker & MK208777 & MK205076 & MK227019 & Tr_S02 & MK226908 & MK226809 & MK227108 \\
\hline T44641 & $4 a$ & -79.866 & 159.365 & Carbonea sp. 2 & JN873871 & - & MK227020 & Tr_A04a & JN204803 & KF907602 & - \\
\hline T44643 & $4 a$ & -79.859 & 159.238 & Lecidea cancriformis Dodge \& Baker & MK208778 & MK205077 & - & Tr_S18 & - & MK226831 & MK227109 \\
\hline T44645 & $4 a$ & -79.857 & 159.283 & Lecidea cancriformis Dodge \& Baker & MK208779 & MK205078 & MK227021 & Tr_S02 & MK226909 & MK226790 & MK227110 \\
\hline T44646 & $4 a$ & -79.857 & 159.283 & Lecidea cancriformis Dodge \& Baker & MK208780 & MK205079 & - & Tr_S02 & MK226910 & MK226793 & MK227111 \\
\hline
\end{tabular}




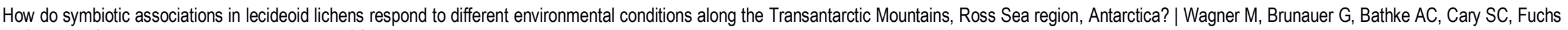
R, Sancho LG, Türk R, Ruprecht U | University of Salzburg

\begin{tabular}{|c|c|c|c|c|c|c|c|c|c|c|c|}
\hline \multirow[b]{3}{*}{ Voucher ID } & \multirow[b]{3}{*}{ Area } & \multirow[b]{3}{*}{ Latitude } & \multirow[b]{3}{*}{ Longitude } & \multicolumn{4}{|c|}{ Mycobiont } & \multicolumn{4}{|c|}{ Associated green micro algae (Trebouxia) } \\
\hline & & & & & \multicolumn{3}{|c|}{ Accession numbers } & & \multicolumn{3}{|c|}{ Accession numbers } \\
\hline & & & & Species name & nrlTS & mtSSU & RPB1 & OTU ID & nrITS2 & psbJ-L & $\operatorname{cox} 2$ \\
\hline T44647 & $4 a$ & -79.858 & 159.288 & Lecidea cancriformis Dodge \& Baker & MK208781 & MK205080 & - & Tr_S02 & MK226911 & MK226794 & MK227112 \\
\hline T44648 & $4 a$ & -79.858 & 159.288 & Lecidea cancriformis Dodge \& Baker & MK208782 & MK205081 & - & - & - & - & - \\
\hline T44649 & $4 a$ & -79.858 & 159.288 & Lecidea cancriformis Dodge \& Baker & MK208783 & MK205082 & - & Tr_S02 & MK226912 & MK226791 & MK227113 \\
\hline T44650 & $4 a$ & -79.858 & 159.288 & Lecanora fuscobrunnea Dodge \& Baker & MK208784 & MK205083 & MK227022 & $\operatorname{Tr} 101$ & MK285376 & - & - \\
\hline T44651 & $4 a$ & -79.858 & 159.288 & Lecidea cancriformis Dodge \& Baker & MK208785 & MK205084 & - & Tr_S02 & MK226913 & MK226795 & MK227114 \\
\hline T44652 & $4 a$ & -79.858 & 159.288 & Lecidea cancriformis Dodge \& Baker & MK208786 & MK205085 & - & Tr_S02 & MK226914 & MK226796 & MK227115 \\
\hline T44655 & $4 a$ & -79.874 & 159.339 & Carbonea sp. 2 & MK208787 & - & MK227023 & Tr_S02 & MK226915 & MK226805 & MK227116 \\
\hline T44656 & $4 a$ & -79.863 & 159.373 & Lecidea cancriformis Dodge \& Baker & MK208788 & MK205086 & - & Tr_S02 & MK226916 & MK226797 & MK227117 \\
\hline T44657 & $4 a$ & -79.863 & 159.373 & Lecanora fuscobrunnea Dodge \& Baker & JN873876 & MK205087 & MK227024 & Tr_S02 & JN204804 & MK226806 & MK227118 \\
\hline T44659 & $4 a$ & -79.864 & 159.368 & Lecidea cancriformis Dodge \& Baker & MK208789 & MK205088 & - & Tr_S02 & MK226917 & MK226798 & MK227119 \\
\hline T44665 & $4 a$ & -79.869 & 159.345 & Lecidea cancriformis Dodge \& Baker & MK208790 & MK205089 & - & Tr_S02 & MK226918 & MK226814 & MK227120 \\
\hline T44666 & $4 a$ & -79.869 & 159.345 & Lecidea cancriformis Dodge \& Baker & MK208791 & MK205090 & - & & - & - & - \\
\hline T44667 & $4 a$ & -79.869 & 159.345 & Lecidea cancriformis Dodge \& Baker & MK208792 & MK205091 & MK227025 & Tr_S02 & MK226919 & MK226782 & MK227121 \\
\hline T44669 & $4 a$ & -79.863 & 159.378 & Lecidea cancriformis Dodge \& Baker & MK208793 & - & - & Tr_S02 & MK226920 & MK226768 & MK227122 \\
\hline T44670 & $4 a$ & -79.863 & 159.378 & Lecidea cancriformis Dodge \& Baker & MK208794 & MK205092 & - & Tr_l17 & MK226921 & - & - \\
\hline T44674 & $4 a$ & -79.877 & 159.326 & Lecidea cancriformis Dodge \& Baker & MK208795 & - & - & Tr_S02 & MK226923 & MK226783 & MK227124 \\
\hline T44675 & $4 a$ & -79.877 & 159.326 & Lecanora fuscobrunnea Dodge \& Baker & - & MK205093 & - & - & JN204806 & - & - \\
\hline T44676 & $4 a$ & -79.883 & 159.348 & Lecidea cancriformis Dodge \& Baker & MK208796 & MK205094 & MK227026 & Tr_S18 & MK226924 & MK226832 & MK227125 \\
\hline T44677 & $4 a$ & -79.883 & 159.348 & Lecidea cancriformis Dodge \& Baker & MK208797 & MK205095 & MK227027 & Tr_A02 & MK226925 & MK226756 & MK227126 \\
\hline T44679 & $4 a$ & -79.877 & 159.331 & Lecidea cancriformis Dodge \& Baker & MK208798 & MK205096 & - & $\operatorname{Tr} \mathrm{S} 02$ & MK226927 & MK226769 & MK227128 \\
\hline T44687 & $4 a$ & -79.863 & 159.379 & Lecanora fuscobrunnea Dodge \& Baker & MK208799 & - & - & - & - & - & MK227130 \\
\hline T44688 & $4 a$ & -79.863 & 159.382 & Lecanora fuscobrunnea Dodge \& Baker & JN873877 & MK205097 & MK227028 & Tr_S02 & JN204807 & MK226807 & MK227131 \\
\hline T44690 & $4 a$ & -79.863 & 159.382 & Lecidea cancriformis Dodge \& Baker & MK208800 & MK205098 & - & Tr_S02 & MK226930 & MK226786 & MK227133 \\
\hline T44692 & $4 a$ & -79.866 & 159.366 & Lecidea cancriformis Dodge \& Baker & MK208801 & MK205099 & MK227029 & Tr_S02 & JN204809 & KF907603 & - \\
\hline T44694 & $4 b$ & -79.755 & 158.503 & Lecidea cancriformis Dodge \& Baker & MK208802 & MK205100 & - & $\operatorname{Tr} \_101$ & MK226931 & - & - \\
\hline T44695 & $4 b$ & -79.761 & 158.503 & Lecanora fuscobrunnea Dodge \& Baker & MK208803 & MK205101 & MK227030 & - & - & - & - \\
\hline T44697 & $4 b$ & -79.758 & 158.598 & Lecanora fuscobrunnea Dodge \& Baker & MK208804 & MK205102 & - & Tr_S02 & MK226932 & MK226770 & MK227134 \\
\hline T44698 & $4 b$ & -79.755 & 158.627 & Lecidea cancriformis Dodge \& Baker & MK208805 & MK205103 & MK227031 & Tr_S18 & MK226933 & MK226825 & MK227135 \\
\hline T44699 & $4 b$ & -79.762 & 158.636 & Lecanora fuscobrunnea Dodge \& Baker & MK208806 & MK205104 & MK227032 & Tr_A02 & MK226934 & MK226758 & MK227136 \\
\hline T44700 & $4 b$ & -79.762 & 158.637 & Lecanora fuscobrunnea Dodge \& Baker & MK208807 & MK205105 & MK227033 & $\operatorname{Tr} 101$ & MK226935 & - & - \\
\hline T44701 & $4 b$ & -79.757 & 158.608 & Lecidea cancriformis Dodge \& Baker & MK208808 & MK205106 & - & $\operatorname{Tr} \mathrm{S} 18$ & MK226936 & MK226833 & MK227137 \\
\hline T44702 & $4 b$ & -79.756 & 158.610 & Lecanora fuscobrunnea Dodge \& Baker & MK208809 & MK205107 & MK227034 & $\operatorname{Tr}$ A02 & MK226937 & MK226759 & MK227138 \\
\hline T44703 & $4 b$ & -79.756 & 158.614 & Lecidea cancriformis Dodge \& Baker & - & MK205108 & MK227035 & $\operatorname{Tr} \mathrm{S} 18$ & MK226938 & MK226828 & MK227139 \\
\hline
\end{tabular}


How do symbiotic associations in lecideoid lichens respond to different environmental conditions along the Transantarctic Mountains, Ross Sea region, Antarctica? | Wagner M, Brunauer G, Bathke AC, Cary SC, Fuchs R, Sancho LG, Türk R, Ruprecht U | University of Salzburg

\begin{tabular}{|c|c|c|c|c|c|c|c|c|c|c|c|}
\hline \multirow[b]{3}{*}{ Voucher ID } & \multirow[b]{3}{*}{ Area } & \multirow[b]{3}{*}{ Latitude } & \multirow[b]{3}{*}{ Longitude } & \multicolumn{4}{|c|}{ Mycobiont } & \multicolumn{4}{|c|}{ Associated green micro algae (Trebouxia) } \\
\hline & & & & \multirow[b]{2}{*}{ Species name } & \multicolumn{3}{|c|}{ Accession numbers } & \multirow[b]{2}{*}{ OTU ID } & \multicolumn{3}{|c|}{ Accession numbers } \\
\hline & & & & & nrlTS & mtSSU & RPB1 & & nrITS2 & psbJ-L & $\operatorname{cox} 2$ \\
\hline T44704 & $4 \mathrm{~b}$ & -79.756 & 158.617 & Lecidea cancriformis Dodge \& Baker & - & MK205109 & - & Tr_S18 & MK226939 & MK226829 & MK227140 \\
\hline T44705 & $4 b$ & -79.756 & 158.611 & Lecanora fuscobrunnea Dodge \& Baker & MK208810 & - & - & Tr_S02 & MK226940 & MK226811 & MK227141 \\
\hline T44707 & $4 b$ & -79.758 & 158.598 & Lecidea cancriformis Dodge \& Baker & MK208811 & MK205110 & MK227036 & Tr_S18 & MK226941 & MK226834 & MK227142 \\
\hline T44708 & $4 b$ & -79.753 & 158.549 & Lecidea cancriformis Dodge \& Baker & MK208812 & MK205111 & - & Tr_S18 & - & MK226823 & MK227143 \\
\hline T44709 & $4 b$ & -79.753 & 158.541 & Lecidea cancriformis Dodge \& Baker & MK208813 & MK205112 & MK227037 & $\operatorname{Tr}$ S18 & MK226942 & MK226826 & MK227144 \\
\hline T44712 & $4 b$ & -79.759 & 158.507 & Lecidea cancriformis Dodge \& Baker & GU074438 & GU074487 & MK227038 & Tr_S18 & JN204811 & - & - \\
\hline T44713 & $4 b$ & -79.759 & 158.511 & Lecidea cancriformis Dodge \& Baker & MK208814 & - & - & $\operatorname{Tr} \mathrm{S} 18$ & MK226945 & MK226836 & MK227147 \\
\hline T44714 & $4 b$ & -79.763 & 158.497 & Lecidea cancriformis Dodge \& Baker & MK208815 & MK205113 & - & $\operatorname{Tr} \mathrm{S} 18$ & MK226946 & MK226830 & MK227148 \\
\hline T44715 & $4 b$ & -79.758 & 158.602 & Lecidea cancriformis Dodge \& Baker & - & MK205114 & MK227039 & Tr_S18 & MK226947 & MK226837 & MK227149 \\
\hline T44716 & $4 b$ & -79.758 & 158.606 & Lecidea cancriformis Dodge \& Baker & - & MK205115 & MK227040 & Tr_S18 & MK226948 & MK226841 & MK227150 \\
\hline T44717 & $4 b$ & -79.755 & 158.620 & Lecanora fuscobrunnea Dodge \& Baker & MK208816 & MK205116 & MK227041 & Tr_S02 & MK226949 & MK226787 & MK227151 \\
\hline T44719 & $4 b$ & -79.924 & 156.814 & Lecanora fuscobrunnea Dodge \& Baker & MK208817 & MK205117 & MK227042 & $\operatorname{Tr} \mathrm{S} 18$ & MK226950 & MK226821 & MK227152 \\
\hline T44720 & $4 b$ & -79.949 & 156.789 & Lecanora fuscobrunnea Dodge \& Baker & GU170840 & MK205118 & MK227043 & Tr_S02 & MK226951 & MK226808 & MK227153 \\
\hline T44721 & $4 b$ & -79.754 & 158.636 & Lecidea cancriformis Dodge \& Baker & MK208818 & MK205119 & MK227044 & $\operatorname{Tr} \mathrm{S} 18$ & MK226952 & MK226842 & MK227154 \\
\hline T44723 & $4 b$ & -79.878 & 157.527 & Lecidea cancriformis Dodge \& Baker & MK208819 & MK205120 & - & Tr_S18 & MK226953 & MK226838 & MK227155 \\
\hline T44727 & $4 b$ & -79.892 & 157.524 & Lecidea cancriformis Dodge \& Baker & GU074437 & GU074488 & - & $\operatorname{Tr} \mathrm{S} 18$ & JN204812 & - & - \\
\hline T44787 & $4 b$ & -79.929 & 156.705 & Lecidea cancriformis Dodge \& Baker & MK208820 & MK205122 & - & $\operatorname{Tr} \mathrm{S} 18$ & MK226955 & MK226839 & MK227157 \\
\hline
\end{tabular}

Supplementary Table S3. Additional samples taken from Perez-Ortega et al. (2012) (Perez-Ortega et al. 2012) and used in this study, with information on collecting localities and Genbank accession numbers.

\begin{tabular}{|c|c|c|c|c|c|c|c|}
\hline \multirow[b]{2}{*}{ Laboratory code } & \multirow[b]{2}{*}{ Area } & \multirow[b]{2}{*}{ Latitude } & \multirow[b]{2}{*}{ Longitude } & \multicolumn{2}{|c|}{ Mycobiont } & \multicolumn{2}{|c|}{ Associated green micro algae (Trebouxia) } \\
\hline & & & & Species name & Accession numbers nrlTS & OTU ID & Accession numbers nrlTS \\
\hline $\begin{array}{l}\text { s106 } \\
\text { s113 } \\
\text { s114 } \\
\text { s115 } \\
\text { s120 } \\
\text { s121 } \\
\text { s122 } \\
\text { s123 }\end{array}$ & $\begin{array}{l}5 \\
5 \\
5 \\
5 \\
5 \\
5 \\
5 \\
5\end{array}$ & $\begin{array}{l}-78.113 \\
-78.114 \\
-78.114 \\
-78.066 \\
-78.083 \\
-78.024 \\
-78.110 \\
-78.110\end{array}$ & $\begin{array}{l}163.782 \\
163.854 \\
163.854 \\
163.870 \\
163.768 \\
163.900 \\
163.787 \\
163.787\end{array}$ & $\begin{array}{l}\text { Lecanora sp. } 2 \\
\text { Lecidea cancriformis Dodge \& Baker } \\
\text { Lecidea cancriformis Dodge \& Baker } \\
\text { Lecidella greenii Ruprecht \& Türk } \\
\text { Lecidea polypycnidophora Ruprecht \& Türk } \\
\text { Carbonea vorticosa (Flörke) Hertel } \\
\text { Carbonea vorticosa (Flörke) Hertel } \\
\text { Carbonea vorticosa (Flörke) Hertel }\end{array}$ & $\begin{array}{l}\text { JX036037 } \\
\text { JX036044 } \\
\text { JX036045 } \\
\text { JX036046 } \\
\text { JX036051 } \\
\text { JX036052 } \\
\text { JX036053 } \\
\text { JX036054 }\end{array}$ & $\begin{array}{l}\text { Tr_A02 } \\
\operatorname{Tr} \_ \text {S15 } \\
\text { Tr_A02 } \\
\text { Tr_A02 } \\
\text { Tr_A02 } \\
\text { Tr_A02 } \\
\text { Tr_A02 } \\
\text { Tr_A02 }\end{array}$ & $\begin{array}{l}\text { JX036159 } \\
\text { JX036166 } \\
\text { JX036167 } \\
\text { JX036168 } \\
\text { JX036172 } \\
\text { JX036173 } \\
\text { JX036174 } \\
\text { JX036175 }\end{array}$ \\
\hline
\end{tabular}




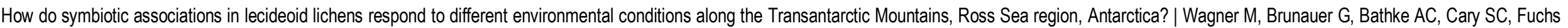
R, Sancho LG, Türk R, Ruprecht U | University of Salzburg

\begin{tabular}{|c|c|c|c|c|c|c|c|}
\hline \multirow[b]{2}{*}{ Laboratory code } & \multirow[b]{2}{*}{ Area } & \multirow[b]{2}{*}{ Latitude } & \multirow[b]{2}{*}{ Longitude } & \multicolumn{2}{|c|}{ Mycobiont } & \multicolumn{2}{|c|}{ Associated green micro algae (Trebouxia) } \\
\hline & & & & Species name & Accession numbers nrlTS & OTU ID & Accession numbers nrlTS \\
\hline s124 & 5 & -78.057 & 163.844 & Rhizoplaca macleanii (Dodge) Castello & JX036055 & Tr_A02 & JX036176 \\
\hline s125 & 5 & -78.057 & 163.844 & Rhizoplaca macleanii (Dodge) Castello & JX036056 & Tr_A02 & JX036177 \\
\hline s171 & 5 & -78.036 & 163.837 & Lecanora sp. 2 & JX036076 & Tr_A02 & JX036197 \\
\hline s173 & 5 & -78.114 & 163.854 & Lecanora sp. 2 & JX036078 & Tr_A02 & JX036199 \\
\hline s175 & 5 & -78.033 & 163.849 & Lecanora sp. 2 & JX036080 & Tr_A02 & JX036201 \\
\hline s179 & 5 & -78.063 & 163.809 & Lecanora sp. 2 & JX036084 & Tr_A02 & JX036205 \\
\hline s181 & 5 & -78.111 & 163.858 & Lecidella greenii Ruprecht \& Türk & JX036086 & Tr_A02 & JX036207 \\
\hline s190 & 5 & -78.025 & 163.899 & Lecanora sp. 3 & JX036095 & Tr_A02 & JX036216 \\
\hline s191 & 5 & -78.025 & 163.900 & Lecanora sp. 3 & JX036096 & Tr_A02 & JX036217 \\
\hline s192 & 5 & -78.030 & 163.834 & Lecidella greenii Ruprecht \& Türk & JX036097 & Tr_A02 & JX036218 \\
\hline s197 & 5 & -78.061 & 163.791 & Rhizoplaca macleanii (Dodge) Castello & JX036101 & Tr_A02 & JX036222 \\
\hline s198 & 5 & -78.061 & 163.791 & Rhizoplaca macleanii (Dodge) Castello & JX036102 & Tr_A02 & JX036223 \\
\hline s201 & 5 & -78.024 & 163.900 & Rhizoplaca macleanii (Dodge) Castello & JX036105 & Tr_A02 & JX036226 \\
\hline s202 & 5 & -78.027 & 163.839 & Lecanora cf. mons-nivis Darbishire & JX036106 & Tr_A02 & JX036227 \\
\hline s203 & 5 & -78.027 & 163.839 & Lecidella greenii Ruprecht \& Türk & JX036107 & Tr_A02 & JX036228 \\
\hline s205 & 5 & -78.068 & 163.861 & Rhizoplaca macleanii (Dodge) Castello & JX036108 & Tr_A02 & JX036229 \\
\hline s206 & 5 & -78.068 & 163.861 & Rhizoplaca macleanii (Dodge) Castello & JX036109 & Tr_A02 & JX036230 \\
\hline s207 & 5 & -78.068 & 163.861 & Rhizoplaca macleanii (Dodge) Castello & JX036110 & $\operatorname{Tr}_{-}^{-} \mathrm{A} 02$ & JX036231 \\
\hline s208 & 5 & -78.068 & 163.861 & Rhizoplaca macleanii (Dodge) Castello & JX036111 & Tr_A02 & JX036232 \\
\hline s209 & 5 & -78.068 & 163.861 & Rhizoplaca macleanii (Dodge) Castello & JX036112 & Tr_A02 & JX036233 \\
\hline s212 & 5 & -78.034 & 163.845 & Rhizoplaca macleanii (Dodge) Castello & JX036115 & $\operatorname{Tr}_{-}^{-} \mathrm{A} 02$ & JX036236 \\
\hline s213 & 5 & -78.034 & 163.845 & Rhizoplaca macleanii (Dodge) Castello & JX036116 & Tr_A02 & JX036237 \\
\hline s214 & 5 & -78.034 & 163.845 & Rhizoplaca macleanii (Dodge) Castello & JX036117 & Tr_A02 & JX036238 \\
\hline s215 & 5 & -78.070 & 163.711 & Lecanora fuscobrunnea Dodge \& Baker & JX036118 & $\operatorname{Tr}_{-}^{-} \mathrm{A} 02$ & JX036239 \\
\hline s230 & 5 & -78.034 & 163.845 & Lecidella greenii Ruprecht \& Türk & JX036133 & Tr_A02 & JX036252 \\
\hline s232 & 5 & -78.034 & 163.845 & Rhizoplaca macleanii (Dodge) Castello & JX036135 & Tr_A02 & JX036254 \\
\hline s233 & 5 & -78.034 & 163.845 & Rhizoplaca macleanii (Dodge) Castello & JX036136 & Tr_A02 & JX036255 \\
\hline s235 & 5 & -78.113 & 163.778 & Rhizoplaca macleanii (Dodge) Castello & JX036138 & Tr_A02 & JX036257 \\
\hline s236 & 5 & -78.113 & 163.778 & Rhizoplaca macleanii (Dodge) Castello & JX036139 & Tr_A02 & JX036258 \\
\hline s237 & 5 & -78.113 & 163.778 & Rhizoplaca macleanii (Dodge) Castello & JX036140 & Tr_A02 & JX036259 \\
\hline s266 & 5 & -78.075 & 163.791 & Lecidella greenii Ruprecht \& Türk & JX036141 & Tr_A02 & JX036260 \\
\hline s271 & 5 & -78.047 & 164.104 & Rhizoplaca macleanii (Dodge) Castello & JX036145 & Tr_A02 & JX036264 \\
\hline s272 & 5 & -78.035 & 163.978 & Rhizoplaca macleanii (Dodge) Castello & JX036146 & Tr_A02 & JX036265 \\
\hline s273 & 5 & -78.030 & 163.949 & Rhizoplaca macleanii (Dodge) Castello & JX036147 & Tr_A02 & JX036266 \\
\hline s274 & 5 & -78.036 & 163.990 & Rhizoplaca macleanii (Dodge) Castello & JX036148 & Tr_A02 & JX036267 \\
\hline
\end{tabular}




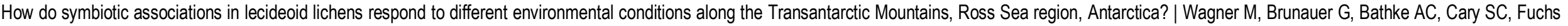
R, Sancho LG, Türk R, Ruprecht U | University of Salzburg

\begin{tabular}{|c|c|c|c|c|c|c|c|}
\hline \multirow[b]{2}{*}{ Laboratory code } & \multirow[b]{2}{*}{ Area } & \multirow[b]{2}{*}{ Latitude } & \multirow[b]{2}{*}{ Longitude } & \multicolumn{2}{|c|}{ Mycobiont } & \multicolumn{2}{|c|}{ Associated green micro algae (Trebouxia) } \\
\hline & & & & Species name & Accession numbers nrlTS & OTU ID & Accession numbers nrlTS \\
\hline $\begin{array}{l}\mathrm{s} 300 \\
\mathrm{~s} 301 \\
\mathrm{~s} 95\end{array}$ & $\begin{array}{l}5 \\
5 \\
5\end{array}$ & $\begin{array}{l}-78.030 \\
-78.030 \\
-78.024\end{array}$ & $\begin{array}{l}163.834 \\
163.834 \\
163.900\end{array}$ & $\begin{array}{l}\text { Lecidella greenii Ruprecht \& Türk } \\
\text { Lecidella greenii Ruprecht \& Türk } \\
\text { Rhizoplaca macleanii (Dodge) Castello }\end{array}$ & $\begin{array}{l}\mathrm{JX036150} \\
\mathrm{JX036151} \\
\mathrm{JX036152}\end{array}$ & $\begin{array}{l}\text { Tr_A02 } \\
\text { Tr_A02 } \\
\text { Tr_A02 }\end{array}$ & $\begin{array}{l}\text { JX036269 } \\
\text { JX036270 } \\
\text { JX036271 }\end{array}$ \\
\hline
\end{tabular}

Supplementary Table S4. Additional samples taken from Wagner et al. (2020) (Wagner et al. 2020) and used in this study, with information on collecting localities and Genbank accession numbers.

\begin{tabular}{|c|c|c|c|c|c|c|c|c|c|c|c|}
\hline \multirow[b]{3}{*}{ Voucher ID } & \multirow[b]{3}{*}{ Area } & \multirow[b]{3}{*}{ Latitude } & \multirow[b]{3}{*}{ Longitude } & \multicolumn{4}{|c|}{ Mycobiont } & \multicolumn{4}{|c|}{ Associated green micro algae (Trebouxia) } \\
\hline & & & & & \multicolumn{3}{|c|}{ Accession numbers } & & \multicolumn{3}{|c|}{ Accession numbers } \\
\hline & & & & Species name & nrlTS & mtSSU & RPB1 & OTU ID & nrlTS & psbJ-L & $\operatorname{cox} 2$ \\
\hline T46643 & 5 & -78.031 & 163.865 & Rhizoplaca macleanii (Dodge) Castello & MK970663 & - & - & Tr_A02 & MK970698 & - & - \\
\hline T46647b & 5 & -78.033 & 163.898 & Rhizoplaca macleanii (Dodge) Castello & MK970665 & MN023039 & MN023053 & Tr_A02 & MK970698 & - & - \\
\hline T46651 & 5 & -78.028 & 163.851 & Carbonea vorticosa (Flörke) Hertel & MK970656 & - & - & - & - & - & - \\
\hline T46659 & 5 & -78.023 & 163.903 & Lecidella greenii Ruprecht \& Türk & MK970671 & - & MN023055 & Tr_A02 & MK970698 & - & - \\
\hline T46672 & 5 & -78.024 & 163.898 & Rhizoplaca macleanii (Dodge) Castello & MK970663 & - & - & Tr_A02 & MK970698 & - & - \\
\hline T46673 & 5 & -78.027 & 163.851 & Rhizoplaca macleanii (Dodge) Castello & MK970663 & - & - & Tr_A02 & MK970699 & - & - \\
\hline T46676 & 5 & -78.028 & 163.851 & Lecidella greenii Ruprecht \& Türk & MK970671 & - & - & Tr_A02 & MK970699 & - & - \\
\hline T46677 & 5 & -78.027 & 163.848 & Lecidea cancriformis Dodge \& Baker & MK970681 & - & - & Tr_A02 & MK970696 & - & - \\
\hline T46678 & 5 & -78.028 & 163.850 & Rhizoplaca macleanii (Dodge) Castello & MK970669 & - & - & Tr_A02 & MK970699 & - & - \\
\hline T46679 & 5 & -78.036 & 163.971 & Rhizoplaca macleanii (Dodge) Castello & MK970664 & MN023039 & - & Tr_A02 & MK970696 & - & - \\
\hline T46680 & 5 & -78.036 & 163.971 & Lecidea polypycnidophora Ruprecht \& Türk & MK970663 & MN023043 & MN023053 & Tr_A02 & MK970699 & - & - \\
\hline T46681 & 5 & -78.032 & 163.951 & Rhizoplaca macleanii (Dodge) Castello & MK970663 & - & - & Tr_A02 & MK970698 & - & - \\
\hline T46684 & 5 & -78.044 & 163.986 & Lecidea cancriformis Dodge \& Baker & MK970677 & - & - & Tr_S02 & MK970693 & - & - \\
\hline T46685 & 5 & -78.044 & 163.986 & Lecidea cancriformis Dodge \& Baker & MK970677 & - & MN023056 & Tr_S02 & MK970693 & - & MN023030 \\
\hline T46701 & 5 & -78.020 & 163.805 & Rhizoplaca macleanii (Dodge) Castello & MK970663 & MN023034 & - & Tr_A02 & MK970698 & - & - \\
\hline T46706 & 5 & -78.028 & 163.821 & Lecidella greenii Ruprecht \& Türk & MK970671 & - & MN023054 & Tr_A02 & MK970698 & - & - \\
\hline T46710 & 5 & -78.073 & 163.717 & Rhizoplaca macleanii (Dodge) Castello & MK970666 & - & - & Tr_A02 & MK970698 & - & - \\
\hline T46713 & 5 & -78.028 & 163.843 & Lecidea polypycnidophora Ruprecht \& Türk & MK970663 & MN023043 & MN023061 & Tr_A02 & MK970698 & - & - \\
\hline T46716 & 5 & -78.040 & 163.802 & Lecidea polypycnidophora Ruprecht \& Türk & MK970663 & MN023043 & MN023061 & Tr_A02 & MK970698 & - & - \\
\hline T46717 & 5 & -78.040 & 163.806 & Lecidea polypycnidophora Ruprecht \& Türk & MK970663 & - & - & Tr_A02 & MK970698 & - & - \\
\hline T46718 & 5 & -78.040 & 163.807 & Carbonea vorticosa (Flörke) Hertel & MK970656 & - & - & Tr_A02 & MK970698 & - & - \\
\hline T46719 & 5 & -78.038 & 163.804 & Carbonea sp. URm1 & MK970657 & - & - & Tr_A02 & MK970698 & - & - \\
\hline
\end{tabular}


How do symbiotic associations in lecideoid lichens respond to different environmental conditions along the Transantarctic Mountains, Ross Sea region, Antarctica? | Wagner M, Brunauer G, Bathke AC, Cary SC, Fuchs R, Sancho LG, Türk R, Ruprecht U | University of Salzburg

\begin{tabular}{|c|c|c|c|c|c|c|c|c|c|c|c|}
\hline \multirow[b]{3}{*}{ Voucher ID } & \multirow[b]{3}{*}{ Area } & \multirow[b]{3}{*}{ Latitude } & \multirow[b]{3}{*}{ Longitude } & \multicolumn{4}{|c|}{ Mycobiont } & \multicolumn{4}{|c|}{ Associated green micro algae (Trebouxia) } \\
\hline & & & & \multirow[b]{2}{*}{ Species name } & \multicolumn{3}{|c|}{ Accession numbers } & \multirow[b]{2}{*}{ OTU ID } & \multicolumn{3}{|c|}{ Accession numbers } \\
\hline & & & & & nrlTS & mtSSU & RPB1 & & nrlTS & psbJ-L & $\operatorname{cox} 2$ \\
\hline T48769 & 5 & -78.126 & 163.700 & Lecidella greenii Ruprecht \& Türk & MK970671 & - & - & Tr_A02 & MK970699 & - & - \\
\hline T48770 & 5 & -78.127 & 163.690 & Lecanora sp. 3 & MK970659 & - & - & Tr_A02 & MK970701 & - & - \\
\hline T48773 & 5 & -78.127 & 163.674 & Lecidea polypycnidophora Ruprecht \& Türk & MK970663 & MN023043 & - & Tr_A02 & MK970699 & MN023065 & - \\
\hline T48774 & 5 & -78.135 & 163.626 & Rhizoplaca macleanii (Dodge) Castello & MK970663 & - & - & Tr_A02 & MK970698 & - & - \\
\hline T48776 & 5 & -78.165 & 163.753 & Lecidea cancriformis Dodge \& Baker & MK970679 & MN023046 & MN023057 & Tr_A02 & MK970702 & - & - \\
\hline T48777 & 5 & -78.166 & 163.755 & Lecidea cancriformis Dodge \& Baker & MK970679 & MN023046 & MN023058 & Tr_S15 & MK970692 & - & MN023031 \\
\hline T48778a & 5 & -78.149 & 163.769 & Rhizoplaca macleanii (Dodge) Castello & MK970663 & - & - & Tr_A02 & MK970698 & - & - \\
\hline T48779 & 5 & -78.164 & 163.755 & Rhizoplaca macleanii (Dodge) Castello & MK970664 & MN023039 & - & Tr_A02 & MK970696 & - & - \\
\hline T48781 & 5 & -78.128 & 163.620 & Lecidea sp. 6 & MK620097 & - & - & Tr_A02 & MK970699 & - & - \\
\hline T48782 & 5 & -78.123 & 163.642 & Lecidea cancriformis Dodge \& Baker & MK970679 & MN023046 & - & Tr_S18 & MK970695 & MN023070 & MN023032 \\
\hline T48784 & 5 & -78.121 & 163.683 & Lecidea polypycnidophora Ruprecht \& Türk & MK970663 & MN023043 & - & Tr_A02 & MK970699 & MN023065 & - \\
\hline T48785 & 5 & -78.133 & 163.666 & Lecidella greenii Ruprecht \& Türk & MK970671 & - & MN023054 & Tr_S15 & MK970692 & - & - \\
\hline T48787 & 5 & -78.127 & 163.678 & Lecidella greenii Ruprecht \& Türk & MK970671 & - & MN023054 & Tr_A02 & MK970699 & - & - \\
\hline T48788 & 5 & -78.120 & 163.684 & Carbonea vorticosa (Flörke) Hertel & MK970656 & MN023033 & MN023050 & Tr_A02 & MK970699 & - & - \\
\hline T48789 & 5 & -78.152 & 163.739 & Carbonea sp. 2 & MK970654 & - & MN023051 & Tr_S15 & MK970692 & - & MN023031 \\
\hline T48790a & 5 & -78.120 & 163.682 & Carbonea vorticosa (Flörke) Hertel & MK970656 & MN023033 & - & Tr_A02 & MK970699 & - & - \\
\hline T48790b & 5 & -78.120 & 163.682 & Lecanora sp. 3 & MK970659 & - & - & Tr_A02 & MK970703 & - & - \\
\hline T48791a & 5 & -78.120 & 163.686 & Lecidella greenii Ruprecht \& Türk & MK970671 & - & - & Tr_A02 & MK970699 & - & - \\
\hline T48793a & 5 & -78.153 & 163.731 & Lecidea cancriformis Dodge \& Baker & MK970677 & - & MN023056 & Tr_S15 & MK970692 & - & MN023031 \\
\hline T48793b & 5 & -78.153 & 163.731 & Carbonea sp. 2 & MK970654 & - & - & Tr_S15 & MK970692 & - & MN023031 \\
\hline T48794b & 5 & -78.151 & 163.735 & Rhizoplaca macleanii (Dodge) Castello & MK970663 & - & - & Tr_A02 & MK970698 & - & - \\
\hline T48795a & 5 & -78.161 & 163.714 & Rhizoplaca macleanii (Dodge) Castello & MK970668 & - & - & Tr_A02 & MK970698 & - & - \\
\hline T48797 & 5 & -78.156 & 163.689 & Rhizoplaca macleanii (Dodge) Castello & MK970667 & - & - & Tr_A02 & MK970698 & - & - \\
\hline T48798 & 5 & -78.150 & 163.736 & Rhizoplaca macleanii (Dodge) Castello & MK970667 & - & - & Tr_A02 & MK970698 & - & - \\
\hline T48799b & 5 & -78.145 & 163.620 & Lecidea cancriformis Dodge \& Baker & MK970679 & - & - & Tr_A02 & MK970698 & - & - \\
\hline T48799c & 5 & -78.145 & 163.620 & Lecidea cancriformis Dodge \& Baker & MK970677 & - & - & Tr_S15 & MK970692 & - & - \\
\hline T48800 & 5 & -78.146 & 163.631 & Lecanora sp. 2 & MK970662 & MN023036 & MN023052 & Tr_A02 & MK970698 & - & - \\
\hline T48801a & 5 & -78.144 & 163.626 & Lecanora sp. 3 & MK970659 & - & - & Tr_A02 & MK970699 & - & - \\
\hline T48801c & 5 & -78.144 & 163.626 & Lecidella greenii Ruprecht \& Türk & MK970671 & MN023040 & - & Tr_A02 & MK970699 & - & - \\
\hline T48803b & 5 & -78.148 & 163.630 & Carbonea sp. URm1 & MK970657 & MN023034 & - & Tr_A02 & MK970699 & - & - \\
\hline T48804 & 5 & -78.148 & 163.630 & Rhizoplaca macleanii (Dodge) Castello & MK970670 & - & MN023053 & Tr_A02 & MK970699 & - & - \\
\hline T48805 & 5 & -78.144 & 163.626 & Lecidella greenii Ruprecht \& Türk & MK970671 & - & - & Tr_A02 & MK970698 & - & - \\
\hline T48806 & 5 & -78.142 & 163.628 & Carbonea sp. URm1 & MK970657 & MN023034 & - & Tr_A02 & MK970699 & - & - \\
\hline
\end{tabular}


How do symbiotic associations in lecideoid lichens respond to different environmental conditions along the Transantarctic Mountains, Ross Sea region, Antarctica? | Wagner M, Brunauer G, Bathke AC, Cary SC, Fuchs R, Sancho LG, Türk R, Ruprecht U | University of Salzburg

\begin{tabular}{|c|c|c|c|c|c|c|c|c|c|c|c|}
\hline \multirow[b]{3}{*}{ Voucher ID } & \multirow[b]{3}{*}{ Area } & \multirow[b]{3}{*}{ Latitude } & \multirow[b]{3}{*}{ Longitude } & \multicolumn{4}{|c|}{ Mycobiont } & \multicolumn{4}{|c|}{ Associated green micro algae (Trebouxia) } \\
\hline & & & & & \multicolumn{3}{|c|}{ Accession numbers } & & \multicolumn{3}{|c|}{ Accession numbers } \\
\hline & & & & Species name & nrlTS & mtSSU & RPB1 & OTU ID & nrlTS & psbJ-L & $\operatorname{cox} 2$ \\
\hline T48807 & 5 & -78.141 & 163.631 & Lecidea andersonii Filson & MK970673 & MN023042 & MN023060 & Tr_A02 & MK970702 & - & - \\
\hline T48809 & 5 & -78.148 & 163.657 & Lecidella greenii Ruprecht \& Türk & MK970671 & - & - & Tr_A02 & MK970699 & - & - \\
\hline T48811a & 5 & -78.142 & 163.657 & Lecidella greenii Ruprecht \& Türk & MK970671 & - & MN023055 & Tr_A02 & MK970698 & - & - \\
\hline T48812a & 5 & -78.138 & 163.619 & Lecidella greenii Ruprecht \& Türk & MK970671 & - & - & Tr_A02 & MK970699 & - & - \\
\hline $\mathrm{T} 48812 \mathrm{~b}$ & 5 & -78.138 & 163.619 & Lecidella greenii Ruprecht \& Türk & MK970671 & - & MN023055 & Tr_A02 & MK970699 & - & - \\
\hline T48813 & 5 & -78.142 & 163.657 & Lecidea UCR1 & MK970675 & MN023044 & - & Tr_A02 & MK970699 & - & - \\
\hline T48817a & 5 & -78.113 & 163.785 & Rhizoplaca macleanii (Dodge) Castello & MK970663 & - & - & Tr_A02 & MK970698 & - & - \\
\hline T48817b & 5 & -78.113 & 163.785 & Carbonea sp. 2 & MK970655 & - & - & Tr_A02 & MK970702 & - & - \\
\hline T48820 & 5 & -78.114 & 163.780 & Carbonea sp. 2 & MK970654 & - & - & Tr_A02 & MK970698 & - & - \\
\hline T48821 & 5 & -78.114 & 163.779 & Rhizoplaca macleanii (Dodge) Castello & MK970665 & - & - & Tr_A02 & MK970698 & - & - \\
\hline T48823a & 5 & -78.098 & 163.710 & Carbonea vorticosa (Flörke) Hertel & MK970656 & - & - & - & - & - & - \\
\hline T48825 & 5 & -78.097 & 163.691 & Carbonea sp. 2 & MK970654 & MN023035 & - & Tr_A02 & MK970699 & - & - \\
\hline T48826 & 5 & -78.097 & 163.717 & Lecanora fuscobrunnea Dodge \& Baker & MK970661 & - & - & Tr_S02 & MK970694 & MN023068 & - \\
\hline T48828a & 5 & -78.110 & 163.858 & Lecidella greenii Ruprecht \& Türk & MK970671 & - & MN023054 & - & - & - & - \\
\hline T48828b & 5 & -78.110 & 163.858 & Lecidella greenii Ruprecht \& Türk & MK970671 & - & - & Tr_A02 & MK970698 & - & - \\
\hline T48829 & 5 & -78.111 & 163.858 & Lecidella greenii Ruprecht \& Türk & MK970671 & - & - & Tr_A02 & MK970699 & - & - \\
\hline T48831 & 5 & -78.111 & 163.858 & Carbonea vorticosa (Flörke) Hertel & MK970656 & MN023033 & - & Tr_A02 & MK970699 & - & - \\
\hline T48832 & 5 & -78.112 & 163.824 & Carbonea sp. 2 & MK970654 & - & MN023051 & Tr_A02 & MK970702 & - & - \\
\hline T48836 & 5 & -78.099 & 163.778 & Lecanora cf. mons-nivis Darbishire & MK970658 & - & - & Tr_A02 & MK970699 & - & - \\
\hline T48837 & 5 & -78.098 & 163.777 & Lecidella greenii Ruprecht \& Türk & MK970671 & - & MN023055 & Tr_A02 & MK970699 & - & - \\
\hline T48839 & 5 & -78.114 & 163.854 & Lecidella greenii Ruprecht \& Türk & MK970671 & - & - & Tr_A02 & MK970699 & - & - \\
\hline T48841a & 5 & -78.068 & 163.861 & Rhizoplaca macleanii (Dodge) Castello & MK970663 & - & - & Tr_A02 & MK970698 & - & - \\
\hline $\mathrm{T} 48841 \mathrm{~b}$ & 5 & -78.068 & 163.861 & Carbonea vorticosa (Flörke) Hertel & MK970656 & - & MN023050 & Tr_A02 & MK970698 & - & - \\
\hline T48843a & 5 & -78.066 & 163.870 & Lecidea cancriformis Dodge \& Baker & MK970677 & - & - & Tr_S02 & MK970693 & - & - \\
\hline T48843c & 5 & -78.066 & 163.870 & Lecidea cancriformis Dodge \& Baker & MK970678 & - & - & - & - & - & - \\
\hline T48843d & 5 & -78.066 & 163.870 & Rhizoplaca macleanii (Dodge) Castello & MK970663 & - & - & Tr_A02 & MK970699 & - & - \\
\hline T48843e & 5 & -78.066 & 163.870 & Rhizoplaca macleanii (Dodge) Castello & MK970663 & - & - & Tr_A02 & MK970702 & - & - \\
\hline T48844 & 5 & -78.067 & 163.863 & Lecidella greenii Ruprecht \& Türk & MK970671 & - & - & Tr_A02 & MK970698 & - & - \\
\hline T48851 & 5 & -78.074 & 163.793 & Lecanora fuscobrunnea Dodge \& Baker & MK970660 & MN023037 & - & Tr_A02 & MK970698 & - & - \\
\hline $\mathrm{T} 48855 \mathrm{~b}$ & 5 & -78.036 & 163.837 & Lecidea cancriformis Dodge \& Baker & MK970680 & MN023046 & MN023059 & Tr_S15 & MK970692 & - & MN023031 \\
\hline T48857a & 5 & -78.036 & 163.827 & Lecidea sp. 6 & MK970684 & MN023045 & - & Tr_A02 & MK970699 & - & - \\
\hline T48858 & 5 & -78.025 & 163.975 & Lecidella greenii Ruprecht \& Türk & MK970671 & - & - & - & - & - & - \\
\hline T48859 & 5 & -78.025 & 163.986 & Lecidea polypycnidophora Ruprecht \& Türk & MK970663 & - & MN023061 & Tr_A02 & MK970698 & - & - \\
\hline
\end{tabular}


How do symbiotic associations in lecideoid lichens respond to different environmental conditions along the Transantarctic Mountains, Ross Sea region, Antarctica? | Wagner M, Brunauer G, Bathke AC, Cary SC, Fuchs R, Sancho LG, Türk R, Ruprecht U | University of Salzburg

\begin{tabular}{|c|c|c|c|c|c|c|c|c|c|c|c|}
\hline \multirow[b]{3}{*}{ Voucher ID } & \multirow[b]{3}{*}{ Area } & \multirow[b]{3}{*}{ Latitude } & \multirow[b]{3}{*}{ Longitude } & \multicolumn{4}{|c|}{ Mycobiont } & \multicolumn{4}{|c|}{ Associated green micro algae (Trebouxia) } \\
\hline & & & & \multirow[b]{2}{*}{ Species name } & \multicolumn{3}{|c|}{ Accession numbers } & \multirow[b]{2}{*}{ OTU ID } & \multicolumn{3}{|c|}{ Accession numbers } \\
\hline & & & & & nrlTS & mtSSU & RPB1 & & nrlTS & psbJ-L & $\operatorname{cox} 2$ \\
\hline T48860b & 5 & -78.036 & 163.836 & Lecidea sp. 6 & MK970684 & MN023045 & MN023064 & Tr_A02 & MK970699 & - & - \\
\hline T48861 & 5 & -78.024 & 163.892 & Lecanora sp. 3 & MK970659 & - & - & Tr_A02 & MK970699 & - & - \\
\hline T48862 & 5 & -78.037 & 163.978 & Lecidea cancriformis Dodge \& Baker & MK970682 & - & - & - & - & - & - \\
\hline T48864 & 5 & -78.039 & 163.989 & Lecidea cancriformis Dodge \& Baker & MK970679 & - & - & Tr_A02 & MK970702 & - & - \\
\hline T48865a & 5 & -78.036 & 163.990 & Rhizoplaca macleanii (Dodge) Castello & MK970666 & - & - & Tr_A02 & MK970698 & MN023067 & - \\
\hline T48867a & 5 & -78.043 & 164.104 & Rhizoplaca macleanii (Dodge) Castello & MK970663 & - & - & Tr_A02 & MK970696 & - & - \\
\hline T48867c & 5 & -78.043 & 164.104 & Rhizoplaca macleanii (Dodge) Castello & MK970666 & - & - & Tr_A02 & MK970702 & - & - \\
\hline T48869 & 5 & -78.037 & 163.978 & Lecidella greenii Ruprecht \& Türk & MK970671 & - & - & - & - & - & - \\
\hline T48872 & 5 & -78.030 & 163.951 & Lecidella greenii Ruprecht \& Türk & MK970671 & - & - & - & - & - & - \\
\hline T48873 & 5 & -78.024 & 163.893 & Lecidella greenii Ruprecht \& Türk & MK970671 & - & MN023054 & Tr_A02 & MK970698 & - & - \\
\hline T48874 & 5 & -78.024 & 163.899 & Lecidea UCR1 & MK970676 & MN023044 & MN023062 & Tr_A02 & MK970697 & MN023066 & - \\
\hline T48875 & 5 & -78.024 & 163.900 & Lecidea lapicida (Ach.) Ach. subsp. & MK970683 & - & - & Tr_A02 & MK970699 & - & - \\
\hline T48876a & 5 & -78.024 & 163.900 & Lecidella greenii Ruprecht \& Türk & MK970671 & MN023040 & - & Tr_A02 & MK970698 & - & - \\
\hline T48876b & 5 & -78.024 & 163.900 & Lecidella greenii Ruprecht \& Türk & MK970671 & - & MN023055 & Tr_A02 & MK970699 & - & - \\
\hline T48877 & 5 & -78.024 & 163.900 & Carbonea vorticosa (Flörke) Hertel & MK970656 & - & MN023050 & Tr_A02 & MK970698 & - & - \\
\hline T48879 & 5 & -78.057 & 163.747 & Lecidella greenii Ruprecht \& Türk & MK970671 & - & MN023055 & - & - & - & - \\
\hline T48880 & 5 & -78.058 & 163.740 & Lecidea polypycnidophora Ruprecht \& Türk & MK970674 & - & - & - & - & - & - \\
\hline T48881b & 5 & -78.061 & 163.791 & Rhizoplaca macleanii (Dodge) Castello & MK970666 & - & - & Tr_A02 & MK970699 & - & - \\
\hline T48882 & 5 & -78.057 & 163.817 & Lecidea polypycnidophora Ruprecht \& Türk & MK970663 & - & - & Tr_A02 & MK970699 & MN023065 & - \\
\hline T48883b & 5 & -78.058 & 163.847 & Lecidea sp. 5 & MK620099 & - & MN023063 & Tr_A02 & MK970700 & - & - \\
\hline T48885 & 5 & -78.057 & 163.844 & Rhizoplaca macleanii (Dodge) Castello & MK970666 & - & - & Tr_A02 & MK970698 & - & - \\
\hline T48887a & 5 & -78.114 & 163.854 & Lecidea cancriformis Dodge \& Baker & MK970677 & - & - & Tr_S15 & MK970692 & - & - \\
\hline T48887a & 5 & -78.070 & 163.711 & Lecidea cancriformis Dodge \& Baker & MK970679 & MN023046 & - & $\operatorname{Tr} \mathrm{S} 15$ & MK970692 & - & - \\
\hline T48888b & 5 & -78.073 & 163.717 & Lecanora cf. mons-nivis Darbishire & MK970658 & - & - & Tr_A02 & MK970699 & - & - \\
\hline T48900 & 5 & -78.034 & 163.845 & Rhizoplaca macleanii (Dodge) Castello & MK970663 & - & - & Tr_A02 & MK970698 & - & - \\
\hline
\end{tabular}


How do symbiotic associations in lecideoid lichens respond to different environmental conditions along the Transantarctic Mountains, Ross Sea region, Antarctica? | Wagner M, Brunauer G, Bathke AC, Cary SC, Fuchs R, Sancho LG, Türk R, Ruprecht U |University of Salzburg bioRxiv preprint doi: https://doi.org/10.1101/2021.05.26.445136; this version posted May 27, 2021. The copyright holder for this preprint (which was not certified by peer review) is the author/funder, who has granted bioRxiv a license to display the preprint in perpetuity. It is made available under aCC-BY-NC-ND 4.0 International license.

Supplementary Table S5. Diversity metrics compared in this study, citations, descriptions and interpretation of each, and the used R functions.

\begin{tabular}{|c|c|c|c|c|}
\hline Metric & Definition & Citations & Description and interpretation of values & R functions, $\mathrm{R}$ package \\
\hline$N R I$ & $\begin{array}{l}\text { Net relatedness } \\
\text { index }\end{array}$ & $\begin{array}{c}\text { Webb, 2000; } \\
\text { Webb, 2002 } \\
\text { (Webb 2000; } \\
\text { Webb et al. } \\
\text { 2002) }\end{array}$ & $\begin{array}{l}\text { Comparison of phylogenetic distances among all } \\
\text { members of a community (pos. values = } \\
\text { phylogenetic clustering; neg. values = } \\
\text { phylogenetic evenness) }\end{array}$ & $\begin{array}{l}\text { ses.mpd(), picante } \\
\text { (Kembel et al. 2010) }\end{array}$ \\
\hline PSR & $\begin{array}{l}\text { Phylogenetic } \\
\text { species richness }\end{array}$ & $\begin{array}{l}\text { Helmus, } 2007 \\
\text { (Helmus et al. } \\
\text { 2007) }\end{array}$ & $\begin{array}{l}\text { PSV (phylogenetic species variability; degree to } \\
\text { which species in a community are } \\
\text { phylogenetically related) multiplied by species } \\
\text { richness SR (number of species in a sample); SR } \\
\text { after discounting species relatedness (values } \\
\text { range from } 0=\text { increased relatedness to SR = } \\
\text { decreased relatedness) }\end{array}$ & $\begin{array}{c}\text { psd(), picante (Kembel et } \\
\text { al. 2010) }\end{array}$ \\
\hline$J^{\prime}$ & $\begin{array}{l}\text { Pielou evenness } \\
\text { index }\end{array}$ & $\begin{array}{l}\text { Pielou, } 1969 \\
\text { (Pielou 1969) }\end{array}$ & $\begin{array}{l}\text { Measure of how evenly distributed abundance is } \\
\text { numerically among the species that exist in a } \\
\text { community (values range from } 0=\text { no evenness } \\
\text { to } 1=\text { complete evenness) }\end{array}$ & $\begin{array}{l}\text { diversity(), vegan } \\
\text { (Oksanen et al. 2019) }\end{array}$ \\
\hline $1-J^{\prime}$ & $\begin{array}{c}1 \text { - Pielou } \\
\text { evenness index }\end{array}$ & & $\begin{array}{l}\text { Values range from } 0=\text { complete evenness to } 1= \\
\text { no evenness }\end{array}$ & \\
\hline
\end{tabular}


Supplementary Table S6. Diversity indices (left), specificity indices (middle) and BIO10, BIO12, elevation and latitude means (right) for the different mycobiont species and photobiont OTUs: $N$, number of sequences; $h$, number of haplotypes; $h / N$, ratio of $h$ and $N ; H d$, haplotype diversity; $\pi$, nucleotide diversity; NRI, net relatedness index; PSR, phylogenetic species richness; $J$ ', Pielou evenness index. (Note: the specificity indices were

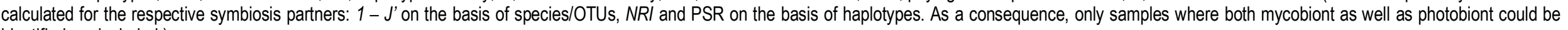
identified are included.)

\begin{tabular}{|c|c|c|c|c|c|c|c|c|c|c|c|c|}
\hline Mycobiont species & $N$ & $h$ & $h / N$ & $H d$ & $\pi$ & $N R I$ & PSR & $1-J$ & $\begin{array}{l}\text { BI010 } \\
\text { mean }\end{array}$ & $\begin{array}{l}\mathrm{BIO12} \\
\text { mean }\end{array}$ & $\begin{array}{l}\text { Elevation } \\
\text { mean } \\
\text { (m. a. s. I.) }\end{array}$ & $\begin{array}{c}\text { Latitude } \\
\text { mean }\end{array}$ \\
\hline Carbonea sp. 2 & 13 & 3 & 0.231 & 0.564 & 0.0014 & 1.238 & 6.473 & 0.220 & -7.33 & 120.85 & 518.83 & -79.79 \\
\hline Carbonea sp. URm1 & 5 & 2 & 0.400 & 0.400 & 0.0128 & -0.297 & 2.913 & 0.743 & -6.78 & 138.00 & 524.40 & -79.95 \\
\hline Carbonea vorticosa & 11 & 1 & 0.091 & - & - & 1.471 & 2.000 & 1.000 & -6.27 & 143.73 & 436.09 & -78.08 \\
\hline Lecanora cf. mons-nivis & 3 & 2 & 0.667 & 0.667 & 0.0000 & 1.413 & 2.000 & 1.000 & -6.30 & 137.33 & 389.33 & -78.07 \\
\hline Lecanora fuscobrunnea & 31 & 6 & 0.194 & 0.546 & 0.0013 & -0.423 & 8.332 & 0.399 & -8.35 & 107.41 & 574.81 & -81.11 \\
\hline Lecanora physciella & 3 & 2 & 0.667 & 0.667 & 0.0014 & 1.473 & 0.011 & 1.000 & -7.70 & 103.67 & 610.33 & -84.04 \\
\hline Lecanora sp. 2 & 6 & 1 & 0.167 & - & - & 2.305 & 3.000 & 1.000 & -6.23 & 141.00 & 606.83 & -78.08 \\
\hline Lecanora sp. 3 & 7 & 1 & 0.143 & - & - & 3.002 & 2.727 & 1.000 & -6.47 & 153.86 & 450.43 & -79.14 \\
\hline Lecidea andersonii & 8 & 1 & 0.125 & - & - & -0.307 & 1.764 & 0.806 & -7.19 & 117.88 & 282.50 & -83.65 \\
\hline Lecidea cancriformis & 93 & 18 & 0.194 & 0.797 & 0.0032 & -1.119 & 10.994 & 0.244 & -8.18 & 112.87 & 601.86 & -80.82 \\
\hline Lecidea lapicida & 1 & 1 & 1.000 & - & - & - & - & 1.000 & -5.90 & 151.00 & 375.00 & -78.02 \\
\hline Lecidea polypycnidophora & 10 & 1 & 0.100 & - & - & 1.471 & 2.000 & 1.000 & -6.22 & 141.10 & 411.20 & -78.06 \\
\hline Lecidea sp. 5 & 1 & 1 & 1.000 & - & - & - & - & 1.000 & -6.50 & 172.00 & 671.00 & -78.06 \\
\hline Lecidea sp. 6 & 3 & 2 & 0.667 & 0.667 & 0.0106 & - & - & 1.000 & -6.33 & 148.67 & 709.00 & -78.07 \\
\hline Lecidea UCR1 & 2 & 1 & 0.500 & - & - & 1.450 & 2.000 & 1.000 & -6.25 & 140.00 & 466.00 & -78.08 \\
\hline Lecidella greenii & 37 & 3 & 0.081 & 0.324 & 0.0007 & 1.933 & 4.600 & 0.929 & -6.33 & 144.95 & 488.57 & -78.53 \\
\hline Lecidella siplei & 10 & 4 & 0.400 & 0.644 & 0.0012 & 2.974 & 2.916 & 1.000 & -7.52 & 136.80 & 322.30 & -84.21 \\
\hline Lecidella sp. nov2 & 9 & 3 & 0.333 & 0.556 & 0.0073 & 1.643 & 0.403 & 0.821 & -7.90 & 100.33 & 787.67 & -83.87 \\
\hline Rhizoplaca macleanii & 51 & 8 & 0.157 & 0.707 & 0.0019 & 4.209 & 4.860 & 1.000 & -6.18 & 149.92 & 684.53 & -78.07 \\
\hline Photobiont OTU & $N$ & $h$ & $h / N$ & $H d$ & $\pi$ & $N R I$ & PSR & $1-J$ & $\begin{array}{l}\text { BI010 } \\
\text { mean }\end{array}$ & $\begin{array}{l}\text { BI012 } \\
\text { mean }\end{array}$ & $\begin{array}{l}\text { Elevation } \\
\text { mean } \\
\text { (m. a. s. I.) }\end{array}$ & $\begin{array}{l}\text { Latitude } \\
\text { mean }\end{array}$ \\
\hline Tr_A02 & 165 & 14 & 0.085 & 0.702 & 0.0025 & 1.739 & 16.265 & 0.220 & -6.47 & 144.24 & 538.61 & -79.20 \\
\hline Tr_A04a & 3 & 3 & 1.000 & 1.000 & 0.0023 & -0.759 & 3.000 & 0.784 & -8.70 & 116.67 & 491.00 & -82.46 \\
\hline Tr_101 & 10 & 6 & 0.600 & 0.844 & 0.0084 & 0.036 & 1.955 & 0.695 & -8.12 & 98.60 & 555.70 & -81.19 \\
\hline $\operatorname{Tr}_{-} \mid 17$ & 2 & 1 & 0.500 & - & - & - & - & 1.000 & -7.60 & 101.50 & 358.50 & -82.21 \\
\hline Tr_S02 & 58 & 8 & 0.138 & 0.573 & 0.0049 & 0.538 & 7.970 & 0.580 & -7.89 & 120.25 & 565.10 & -82.12 \\
\hline Tr_S15 & 10 & 1 & 0.100 & - & - & 0.578 & 2.596 & 0.728 & -6.16 & 139.10 & 689.10 & -78.12 \\
\hline Tr_S18 & 32 & 1 & 0.031 & - & - & 2.529 & 3.431 & 0.828 & -9.91 & 77.88 & 696.25 & -80.02 \\
\hline
\end{tabular}


How do symbiotic associations in lecideoid lichens respond to different environmental conditions along the Transantarctic Mountains, Ross Sea region, Antarctica? I Wagner M, Brunauer G, Bathke AC, Cary SC, Fuchs R, Sancho LG, Türk R, Ruprecht U | University of Salzburg bioRxiv preprint doi: https://doi.org/10.1101/2021.05.26.445136; this version posted May 27, 2021. The copyright holder for this preprint (which was not certified by peer review) is the author/funder, who has granted bioRxiv a license to display the preprint in perpetuity. It is made available under aCC-BY-NC-ND 4.0 International license.

Supplementary Table S7. Network matrix giving the number of associations between the mycobiont species and photobiont OTUs.

\begin{tabular}{l|ccccccc} 
& \multicolumn{7}{c}{ Photobiont OTU } \\
Mycobiont species & Tr_A02 & Tr_A04a & Tr_101 & Tr_I17 & Tr_S02 & Tr_S15 & Tr_S18 \\
\hline Carbonea sp. 2 & 4 & 2 & - & - & 3 & 2 & 1 \\
Carbonea sp. URm1 & 4 & - & 1 & - & - & - & - \\
Carbonea vorticosa & 9 & - & - & - & - & - & - \\
Lecanora cf. mons-nivis & 3 & - & - & - & - & - & - \\
Lecanora fuscobrunnea & 11 & - & 3 & - & 11 & - & 2 \\
Lecanora physciella & - & - & - & - & 2 & - & - \\
Lecanora sp. 2 & 6 & - & - & - & - & - & - \\
Lecanora sp. 3 & 7 & - & - & - & - & - & - \\
Lecidea andersonii & 7 & - & - & - & 1 & - & - \\
Lecidea cancriformis & 7 & 1 & 6 & 2 & 34 & 7 & 28 \\
Lecidea lapicida & 1 & - & - & - & - & - & - \\
Lecidea polypycnidophora & 9 & - & - & - & - & - & - \\
Lecidea sp. 5 & 1 & - & - & - & - & - & - \\
Lecidea sp. 6 & 3 & - & - & - & - & - & - \\
Lecidea UCR1 & 2 & - & - & - & - & - & - \\
Lecidella greenii & 31 & - & - & - & - & 1 & - \\
Lecidella siplei & 9 & - & - & - & - & - & - \\
Lecidella sp. nov2 & - & - & - & - & 8 & - & 1 \\
Rhizoplaca macleanii & 51 & - & - & - & - & - & -
\end{tabular}

\section{References}

Doran PT, McKay CP, Clow GD, Dana GL, Fountain AG, Nylen T, Lyons WB (2002) Valley floor climate observations from the McMurdo Dry Valleys, Antarctica, 1986-2000 Journal of Geophysical Research: Atmospheres 107:ACL 13-11-ACL 13-12

Gunn BM, Walcott RI (1962) The geology of the Mt Markham region, Ross dependency, Antarctica New Zealand Journal of Geology and Geophysics 5:407-426

Helmus MR, Bland TJ, Williams CK, Ives AR (2007) Phylogenetic measures of biodiversity American Naturalist 169:E68-E83 doi:Doi $10.1086 / 511334$

Kembel SW et al. (2010) Picante: $R$ tools for integrating phylogenies and ecology Bioinformatics 26:1463-1464 doi:10.1093/bioinformatics/btq166

Oksanen J et al. (2019) vegan: Community Ecology Package. R package version 2.5-6.

Perez-Ortega S, Ortiz-Alvarez R, Allan Green TG, de Los Rios A (2012) Lichen myco- and photobiont diversity and their relationships at the edge of life (McMurdo Dry Valleys, Antarctica) FEMS Microbiol Ecol 82:429-448 doi:10.1111/j.1574-6941.2012.01422.x

Pielou EC (1969) An Introduction to Mathematical Ecology. Wiley, New York

Simpson AL, Cooper AF (2002) Geochemistry of the Darwin Glacier region granitoids, southern Victoria Land Antarct Sci 14:425-426 doi:10.1017/S0954102002000226

Stichbury G, Brabyn L, Allan Green T, Cary C (2011) Spatial modelling of wetness for the Antarctic Dry Valleys Polar Research 30:6330

Wagner M, Bathke AC, Cary SC, Green TGA, Junker RR, Trutschnig W, Ruprecht U (2020) Myco- and photobiont associations in crustose lichens in the McMurdo Dry Valleys (Antarctica) reveal high differentiation along an elevational gradient Polar Biology 43:19671983 doi:10.1007/s00300-020-02754-8

Webb CO (2000) Exploring the phylogenetic structure of ecological communities: An example for rain forest trees American Naturalist 156:145-155 doi:Doi 10.1086/303378

Webb CO, Ackerly DD, McPeek MA, Donoghue MJ (2002) Phylogenies and community ecology Annual Review of Ecology and Systematics 33:475-505 doi:10.1146/annurev.ecolysis.33.010802.150448

Yung CCM et al. (2014) Characterization of Chasmoendolithic Community in Miers Valley, McMurdo Dry Valleys, Antarctica Microb Ecol 68:351-359 
How do symbiotic associations in lecideoid lichens respond to different environmental conditions along the Transantarctic Mountains, Ross Sea region, Antarctica? | Wagner M, Brunauer G, Bathke AC, Cary SC, Fuchs R, Sancho LG, Türk R, Ruprecht U | University of Salzburg bioRxiv preprint doi: https://doi.org/10.1101/2021.05.26.445136; this version posted May 27, 2021. The copyright holder for this preprint (which was not certified by peer review) is the author/funder, who has granted bioRxiv a license to display the preprint in perpetuity. It is made

Supplementary Material 2: Figures

\section{Contents}

$\begin{array}{lc} & \text { Page } \\ \text { Supplementary Figure S1 } & 2 \\ \text { Supplementary Figure S2 } & 3 \\ \text { Supplementary Figure S3 } 3 & 4 \\ \text { Supplementary Figure S4 } & 5 \\ \text { Supplementary Figure S5 } & 6 \\ \text { Supplementary Figure S6 } & 6 \\ \text { Supplementary Figure S7 } & 7 \\ \text { Supplementary Figure S8 } & \\ \text { Supplementary Figure S9 } & \\ \text { Supplementary Figure S10 } & 8 \\ \text { References } & 8\end{array}$


How do symbiotic associations in lecideoid lichens respond to different environmental conditions along the Transantarctic Mountains, Ross Sea region, Antarctica? I Wagner M, Brunauer G, Bathke AC, Cary SC, Fuchs R, Sancho LG, Türk R, Ruprecht U University of Salzburg bioRxiv preprint doi: https://doi.org/10.1101/2021.05.26.445136; this version posted May 27, 2021. The copyright holder for this preprint (which was not certified by peer review) is the author/funder, who has granted bioRxiv a license to display the preprint in perpetuity. It is made available under aCC-BY-NC-ND 4.0 International license.

Supplementary Figure S1. Phylogeny of mycobiont specimen based on multi-locus sequence data (nrlTS, mtSSU and RPB1; calculated with IQ-TREE (Nguyen et al. 2014); branches with SH-aLRT < $80 \%$ and UFboot $<95 \%$ were collapsed).

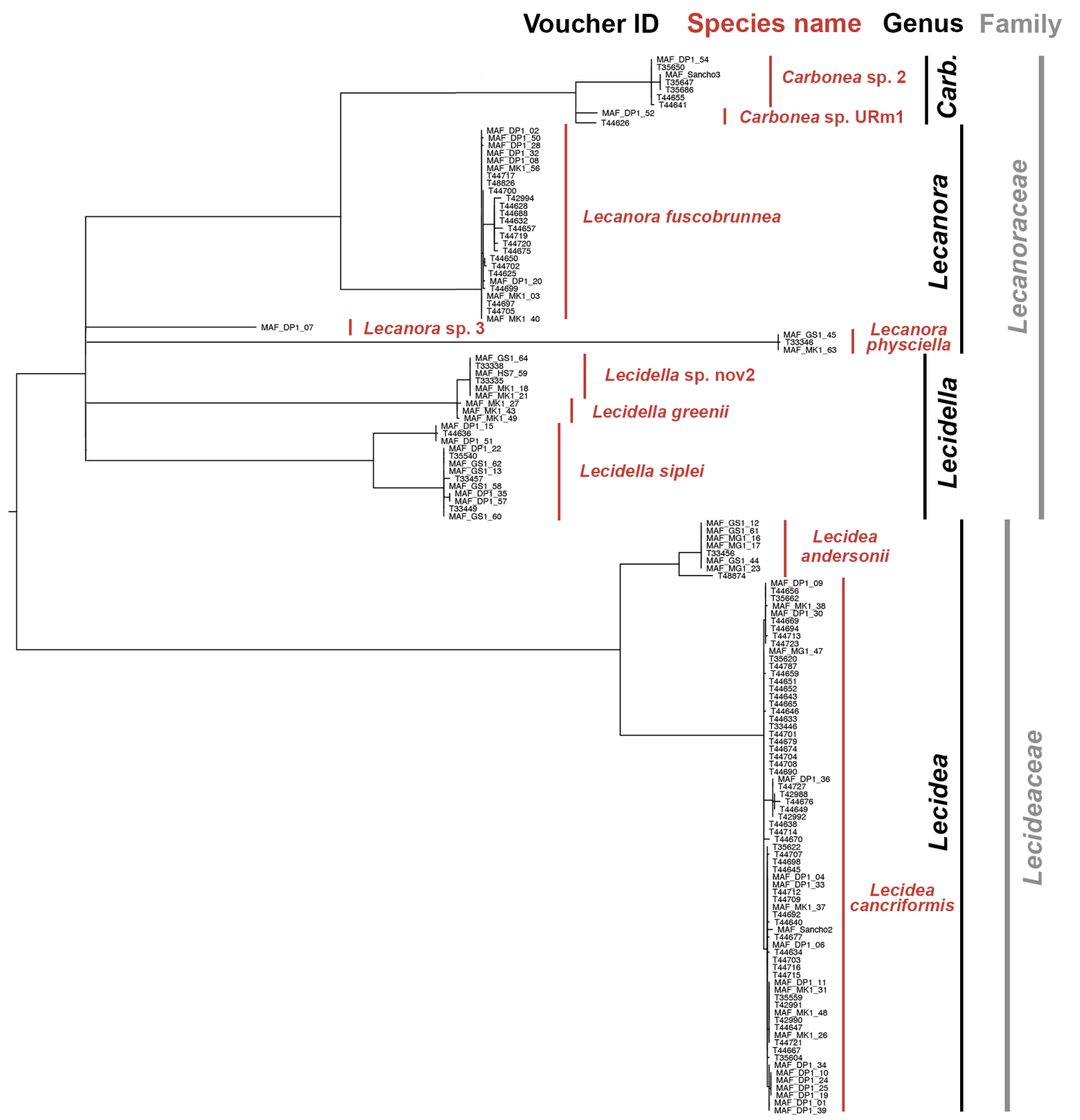


How do symbiotic associations in lecideoid lichens respond to different environmental conditions along the Transantarctic Mountains, Ross Sea region, Antarctica? I Wagner M, Brunauer G, Bathke AC, Cary SC, Fuchs R, Sancho LG, Türk R, Ruprecht U University of Salzburg bioRxiv preprint doi: https://doi.org/10.1101/2021.05.26.445136; this version posted May 27, 2021. The copyright holder for this preprint (which was not certified by peer review) is the author/funder, who has granted bioRxiv a license to display the preprint in perpetuity. It is made available under aCC-BY-NC-ND 4.0 International license.

Supplementary Figure S2. Phylogeny of all mycobiont specimen based on the marker nrlTS (calculated with IQ-TREE (Nguyen et al. 2014); branches with SH-aLRT $<80 \%$ and UFboot $<95 \%$ were collapsed).

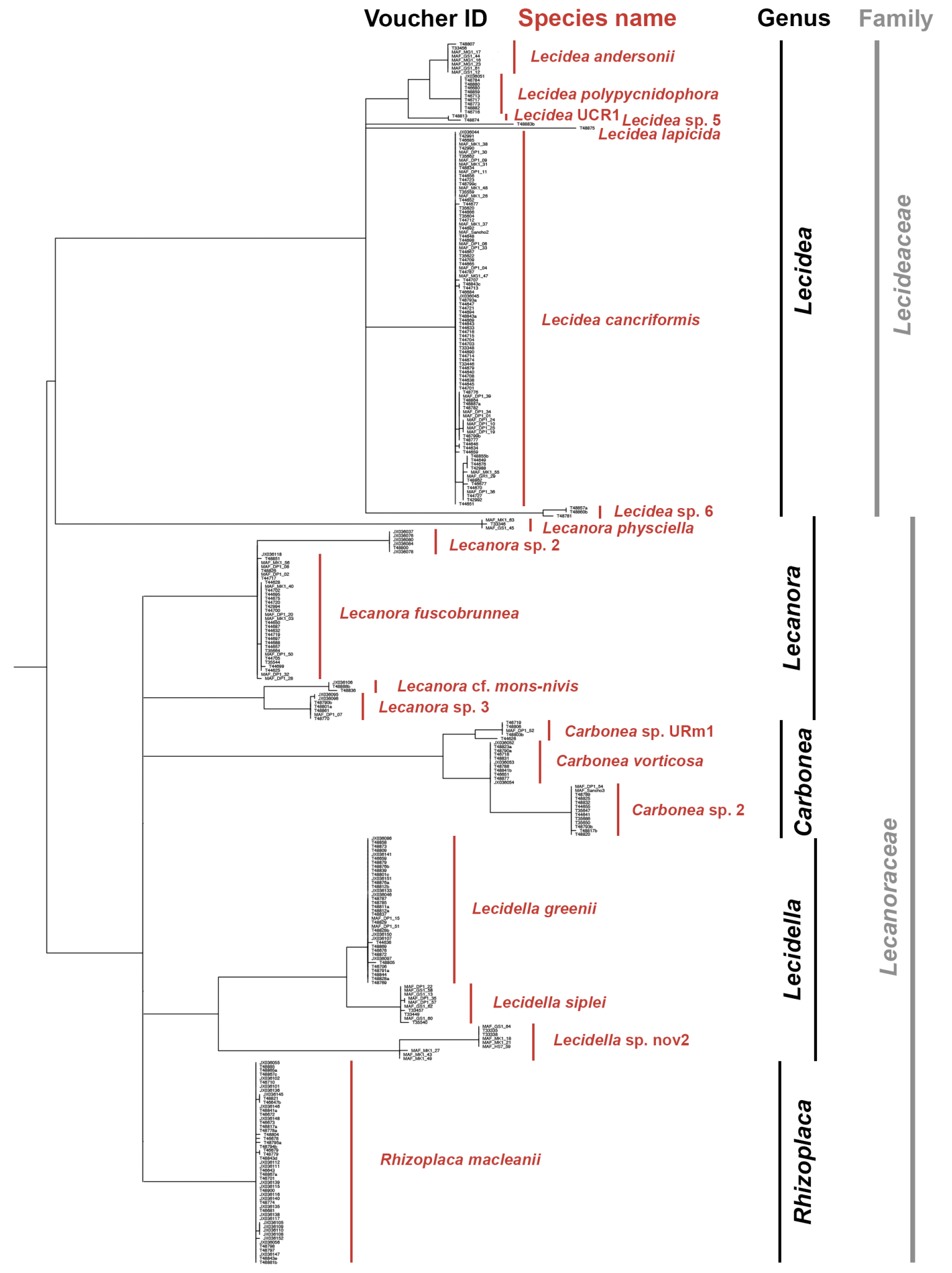


How do symbiotic associations in lecideoid lichens respond to different environmental conditions along the Transantarctic Mountains, Ross Sea region, Antarctica? I Wagner M, Brunauer G, Bathke AC, Cary SC, Fuchs R, Sancho LG, Türk R, Ruprecht U University of Salzburg bioRxiv preprint doi: https://doi.org/10.1101/2021.05.26.445136; this version posted May 27, 2021. The copyright holder for this preprint (which was not certified by peer review) is the author/funder, who has granted bioRxiv a license to display the preprint in perpetuity. It is made available under aCC-BY-NC-ND 4.0 International license.

Supplementary Figure S3. Phylogeny of photobiont specimen based on multi-locus sequence data (nrlTS, psbJ-L and COX2; calculated with IQ-TREE (Nguyen et al. 2014); branches with SH-aLRT $<80 \%$ and UFboot $<95 \%$ were collapsed).

Voucher ID

OTU ID

Genus

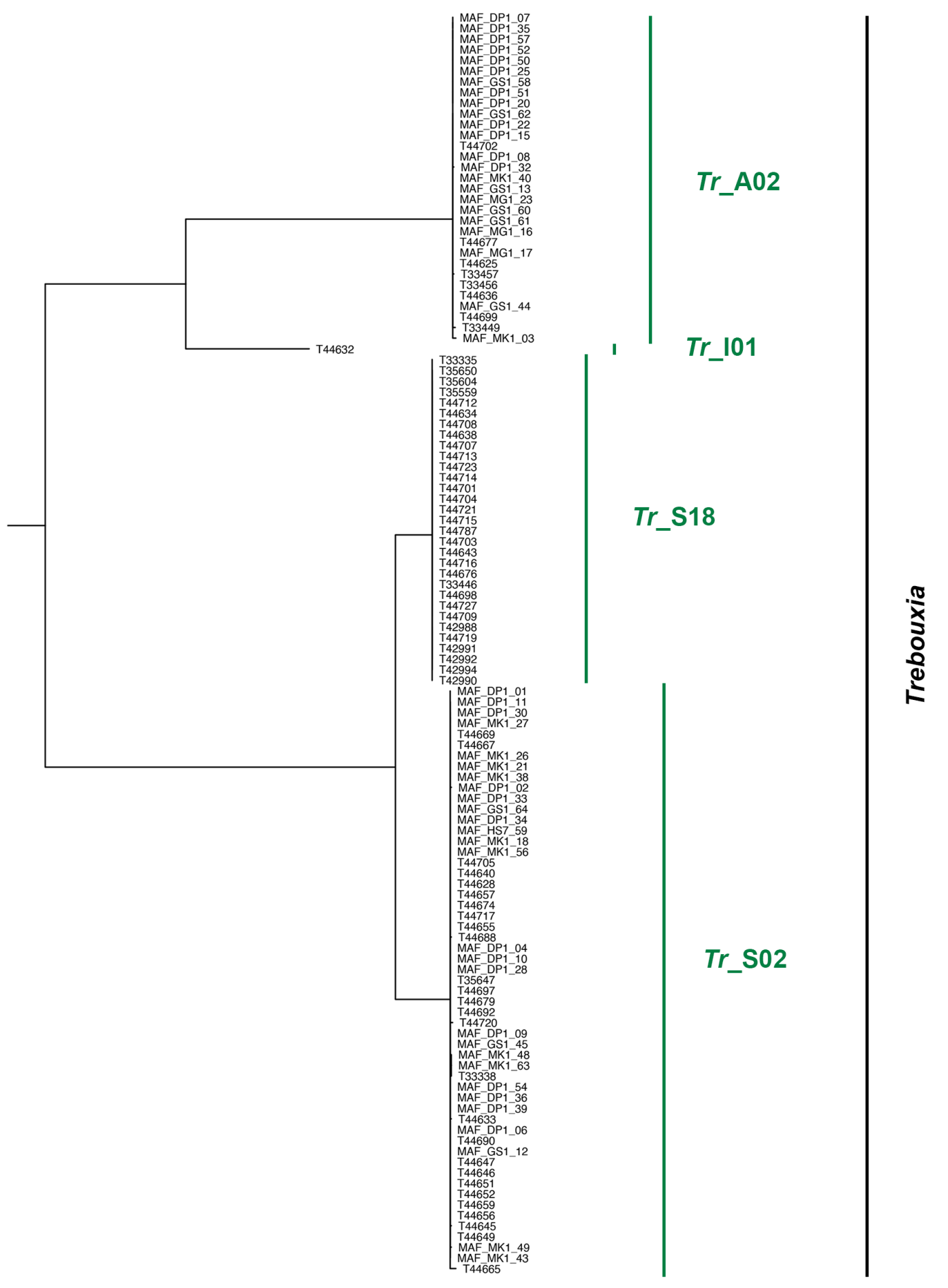


How do symbiotic associations in lecideoid lichens respond to different environmental conditions along the Transantarctic Mountains, Ross Sea region, Antarctica? I Wagner M, Brunauer G, Bathke AC, Cary SC, Fuchs R, Sancho LG, Türk R, Ruprecht U University of Salzburg bioRxiv preprint doi: https://doi.org/10.1101/2021.05.26.445136; this version posted May 27, 2021. The copyright holder for this preprint (which was not certified by peer review) is the author/funder, who has granted bioRxiv a license to display the preprint in perpetuity. It is made available under aCC-BY-NC-ND 4.0 International license.

Supplementary Figure S4. Phylogeny of all photobiont specimen based on the marker nrITS (calculated with IQ-TREE (Nguyen et al. 2014); branches with SH-aLRT $<80 \%$ and UFboot $<95 \%$ were collapsed).

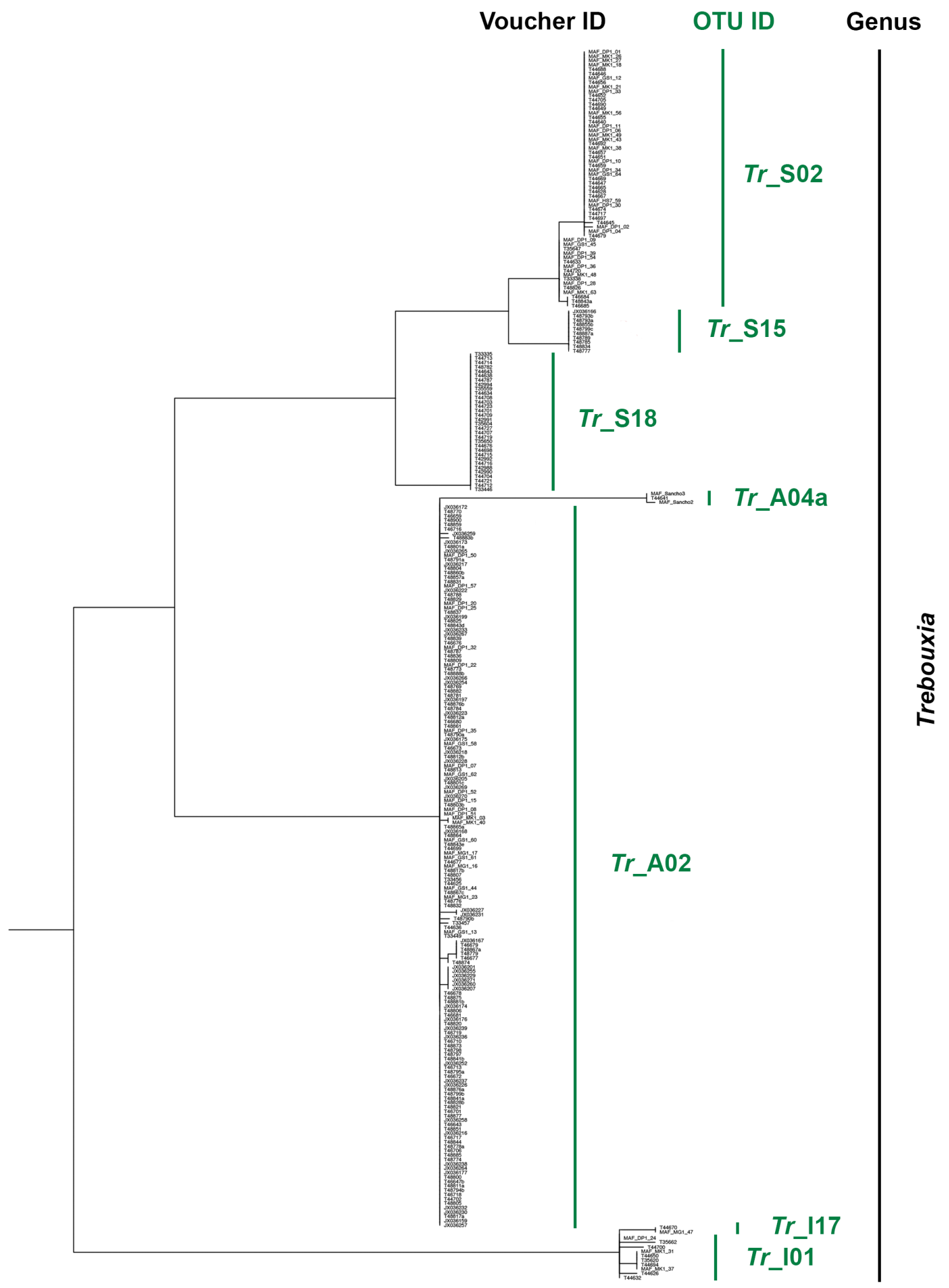


How do symbiotic associations in lecideoid lichens respond to different environmental conditions along the Transantarctic Mountains, Ross Sea region, Antarctica? I Wagner M, Brunauer G, Bathke AC, Cary SC, Fuchs R, Sancho LG, Türk R, Ruprecht U | University of Salzburg bioRxiv preprint doi: https://doi.org/10.1101/2021.05.26.445136; this version posted May 27, 2021. The copyright holder for this preprint (which was not certified by peer review) is the author/funder, who has granted bioRxiv a license to display the preprint in perpetuity. It is made available under aCC-BY-NC-ND 4.0 International license.

Supplementary Figure S5. Barplots giving the number of samples per mycobiont species/ photobiont OTU and area included in this study. (a) Mycobiont species (total sample size: $n=306$ ), (b) photobiont OTUs (total sample size: $n=281$ ).
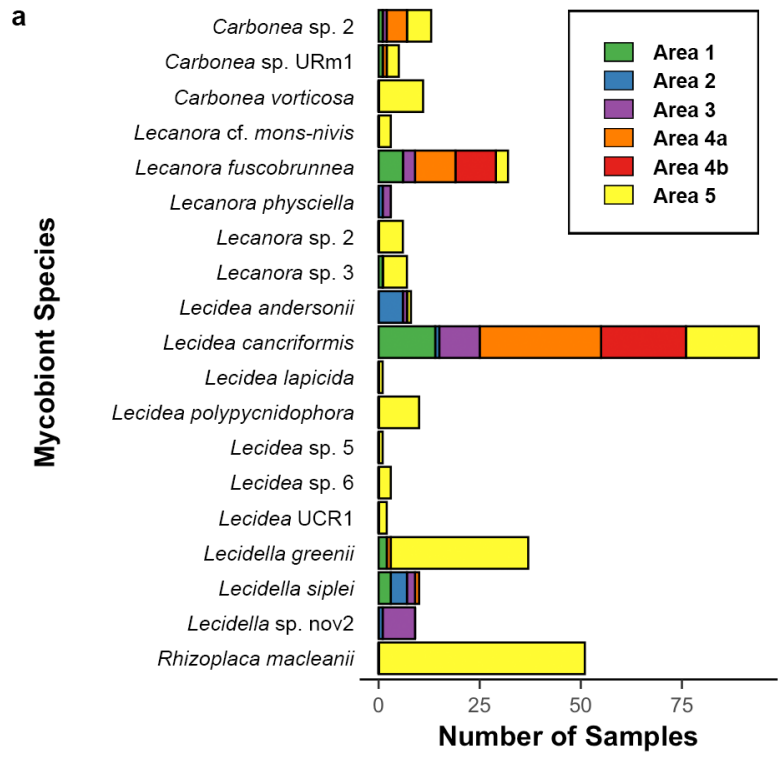

b

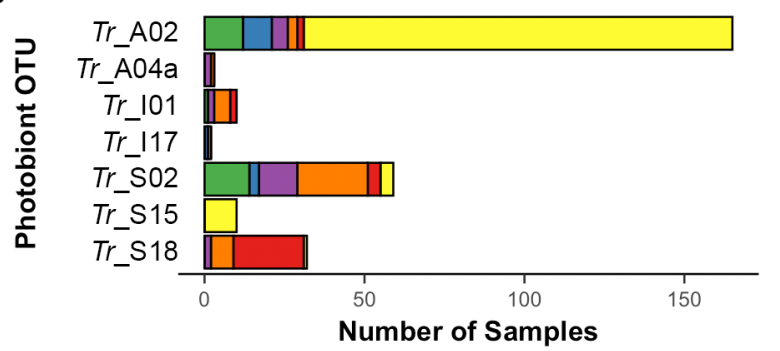

Supplementary Figure S6. Correlation plot. Percentage of Trebouxia OTU A02 samples against mean values of BIO10 (mean temperature of warmest quarter) for the different areas.

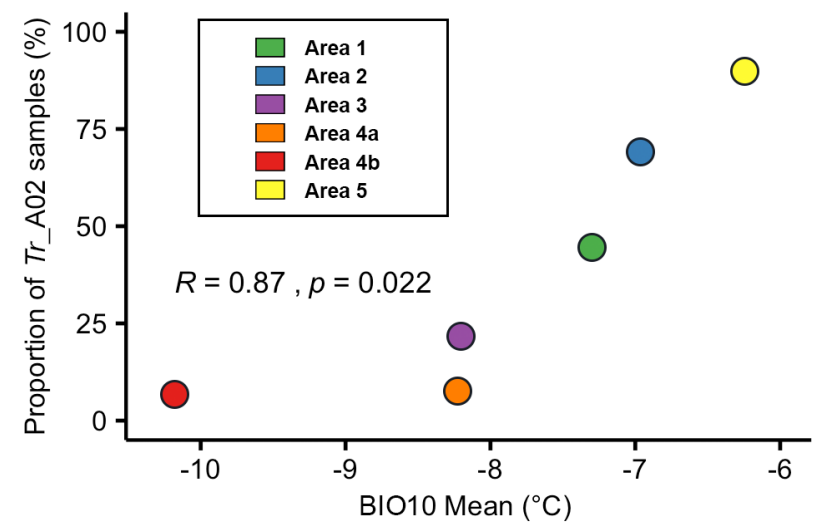


How do symbiotic associations in lecideoid lichens respond to different environmental conditions along the Transantarctic Mountains, Ross Sea region, Antarctica? I Wagner M, Brunauer G, Bathke AC, Cary SC, Fuchs R, Sancho LG, Türk R, Ruprecht U | University of Salzburg bioRxiv preprint doi: https://doi.org/10.1101/2021.05.26.445136; this version posted May 27, 2021. The copyright holder for this preprint (which was not certified by peer review) is the author/funder, who has granted bioRxiv a license to display the preprint in perpetuity. It is made available under aCC-BY-NC-ND 4.0 International license.

Supplementary Figure S7. Correlation plot. Alpha diversity values of mycobiont species against BIO10 (mean temperature of warmest quarter) mean values of the different areas.

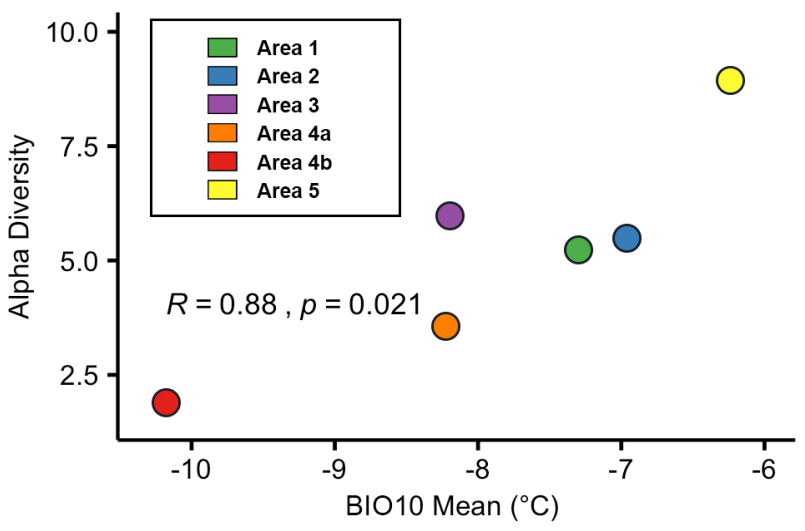

Supplementary Figure S8. Ordination plots showing the similarity of mycobiont samples with $n \geq 10$ after constrained analysis of principal coordinates. Samples located closer to each other are also more similar in terms of the environmental factors elevation, BIO10 and BIO12. The first constrained axis CAP1 explained $13.77 \%$ of the variance, the second constrained axis CAP2 $1.76 \%$ of the variance. Only the first axis was significant $(F=17.1640, p=0.001)$.

\begin{tabular}{|lll|}
\hline Mycobiont species & & \\
$\square$ Carbonea sp. 2 & $\square$ Lecidea cancriformis & $\square$ Lecidella siplei \\
$\square$ Carbonea vorticosa & $\square$ Lecidea polypycnidophora \\
$\square$ Lecanora fuscobrunnea & $\square$ Lecidella greenii \\
\hline
\end{tabular}
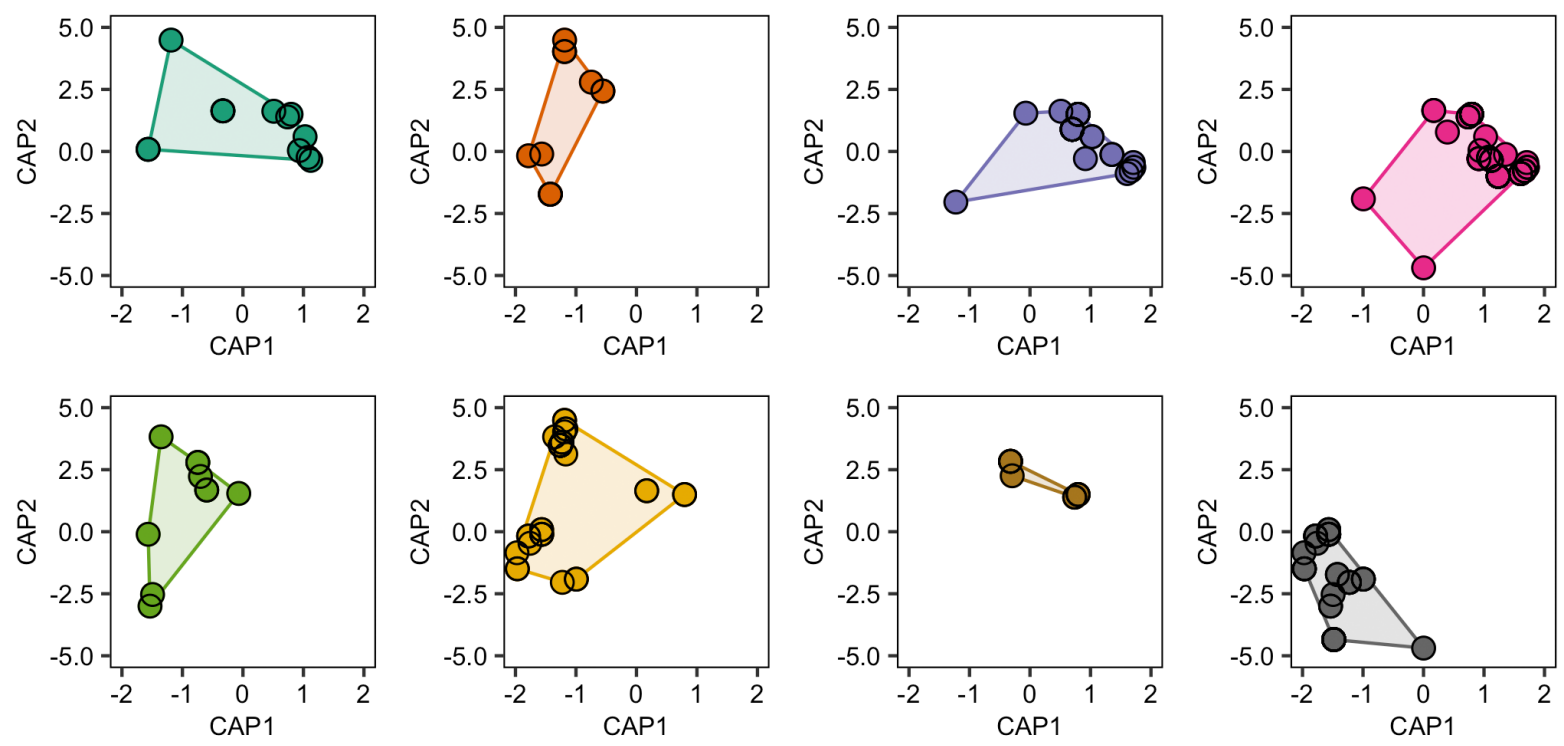
How do symbiotic associations in lecideoid lichens respond to different environmental conditions along the Transantarctic Mountains, Ross Sea region, Antarctica? I Wagner M, Brunauer G, Bathke AC, Cary SC, Fuchs R, Sancho LG, Türk R, Ruprecht U | University of Salzburg bioRxiv preprint doi: https://doi.org/10.1101/2021.05.26.445136; this version posted May 27, 2021. The copyright holder for this preprint (which was not certified by peer review) is the author/funder, who has granted bioRxiv a license to display the preprint in perpetuity. It is made available under aCC-BY-NC-ND 4.0 International license.

Supplementary Figure S9. Ordination plots showing the similarity of photobiont OTUS with $n \geq 10$ after constrained analysis of principal coordinates. Samples located closer to each other are also more similar in terms of the environmental factors elevation, BIO10 and BIO12. The first constrained axis CAP1 explained $36.87 \%$ of the variance, the second constrained axis CAP2 $1.46 \%$ of the variance. Only the first axis was significant $(F=57.0275, p=0.001)$.

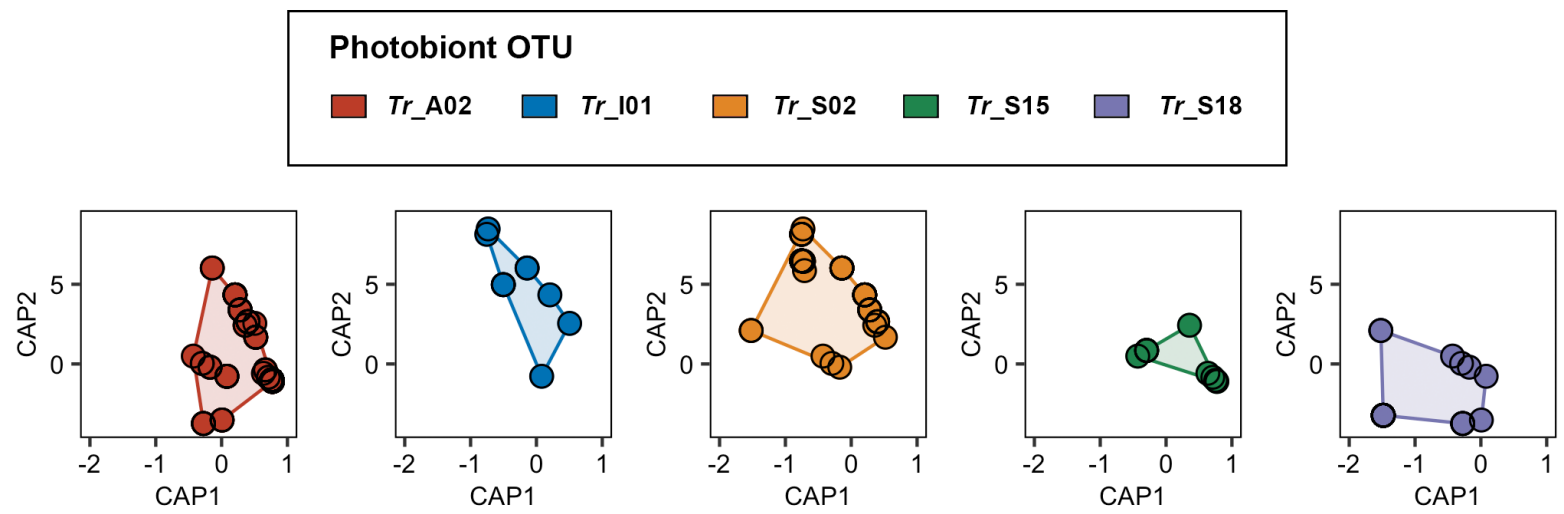

Supplementary Figure S10. Haplotype networks based on multi-locus sequence data, showing the spatial distribution within the different areas. (a) Lecidea cancriformis, (b) Trebouxia OTU S02. Roman numerals at the center of the pie charts refer to the haplotype IDs based on ITS data (cf., Fig. 2 and Fig. 3 of main text). The italic numbers next to the pie charts give the total number of samples per haplotype. The circle sizes reflect relative frequency within the species; the frequencies were clustered in ten (e.g. the circles of all haplotypes making up between $20-30 \%$ have the same size).

a

\section{Lecidea cancriformis}

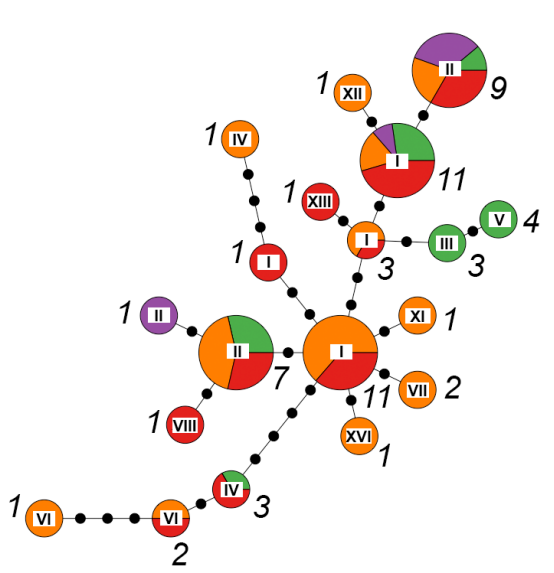

b Trebouxia OTU S02

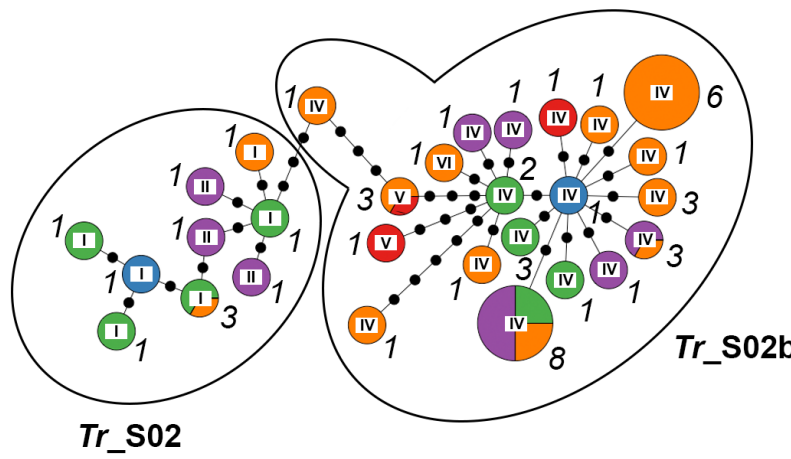

Area 1

Area 2

Area 3

Area 4a

Area 4b

Area 5

\section{References}

Nguyen L-T, Schmidt HA, von Haeseler A, Minh BQ (2014) IQ-TREE: A Fast and Effective Stochastic Algorithm for Estimating MaximumLikelihood Phylogenies Molecular Biology and Evolution 32:268-274 doi:10.1093/molbev/msu300 